\author{
UNIVERSIDADE DE SÃO PAULO \\ FACULDADE DE FILOSOFIA LETRAS E CIÊNCIAS HUMANAS \\ DEPARTAMENTO DE GEOGRAFIA \\ PROGRAMA DE PÓS-GRADUAÇÃO EM GEOGRAFIA HUMANA
}

\title{
ORGANIZAÇÃO, ESTRUTURA E IMPACTOS DAS COLÔNIAS DE FÉRIAS DE TRABALHADORES: ALGUNS ESTUDOS DE CASO
}

\author{
Luís Roberto Karklis
}

Dissertação de Mestrado apresentada ao Programa de Pós-Graduação em Geografia Humana, do Departamento de Geografia da Faculdade de Filosofia, Letras e Ciências Humanas da Universidade de São Paulo, para a obtenção do título de Mestre em Geografia.

Orientador: Prof. Dr. Eduardo Abdo Yázigi

São Paulo

2008

KARKLIS, LUÍS ROBERTO 


\section{FOLHA DE APROVAÇÃO}

Luís Roberto Karklis

ORGANIZAÇÃO, ESTRUTURA E IMPACTOS DAS COLÔNIAS DE FÉRIAS DE TRABALHADORES: ALGUNS ESTUDOS DE CASO

Dissertação de Mestrado apresentada ao Programa de Pós-Graduação em Geografia Humana, do Departamento de Geografia da Faculdade de Filosofia, Letras e Ciências Humanas da Universidade de São Paulo, para a obtenção do título de Mestre em Geografia.

Aprovada em

Banca Examinadora

Prof.

Dr. assinatura

Instituição

Prof.

Dr. assinatura Instituição

Prof.Dr. assinatura

Instituição 
RESUMO

As colônias de férias de trabalhadores são uma modalidade de hospedagem voltada para o estrato das camadas sociais de poder aquisitivo que de uma forma geral necessitam de algum subsídio para o custeio da estadia. Comumente são ligadas ao Turismo Social praticados por entidades como associações e sindicatos. No Brasil sua maior concentração geográfica se dá no estado de São Paulo, sobretudo no litoral e nas regiões serranas. A importância do trabalho justifica-se porque as colônias de férias são um meio de democratização do turismo, pois, simplesmente em sua essência barateiam os custos de hospedagem e podem agregar atividades culturais que tornam o lazer mais ativo. Como objeto de estudo da Geografia nos revela importantes debates como as preocupações com a ocupação do território podendo agregar qualidade ambiental, paisagística e geração de empregos aos municípios. Despertam também a necessidade de se pensar em políticas públicas voltadas para o incentivo desse tipo de turismo, não apenas por conta das questões territoriais, mas principalmente por envolverem atores, como as associações e os sindicatos, que são as principais entidades ligadas ao fenômeno e merecem atenção por serem os responsáveis pelos empreendimentos e pela gestão. Neste estudo de caso deparamo-nos com o fenômeno da maior concentração mundial desse meio de hospedagem no município de Praia Grande, litoral do Estado de São Paulo. Exigindo atenção dos governantes e das próprias associações e sindicatos, que por sua vez, podem otimizar com qualidade o turismo e o lazer do trabalhador e de sua família. 


\section{SUMMARY}

Employee holiday resorts are a form of lodging for those on the social scale which would generally benefit from assistance with vacation expenses. They are commonly associated with Social Tourism practiced by entities such as workers' associations and unions. In Brazil, the majority of these resorts are located in Sao Paulo, mainly on the coastline and in mountainous regions. The importance of work is substantiated because the

holiday resorts are a way to democratize tourism, essentially lowering the cost of lodging and possibly adding cultural activities which allow for a more purposeful leisure time. As a geographical object of study, important debates are revealed such as concern for the use of the land, the ability to aggregate environmental and scenic quality and generate jobs in the surrounding municipalities. The need to contemplate political policy encouraging this type of tourism is also brought up, not only concerning territorial issues but also concerning the involvement of workers' associations and unions which are the main entities connected with this phenomenon and deserve attention for being those responsible for management and enterprising. In this study we find that the world's highest concentration of this type of lodging is located in the Praia Grande municipality on the Sao Paulo state coastline. This phenomenon demands governmental attention, as well as the attention of the workers' associations and unions themselves, because they are able optimize the quality of tourism and leisure time for workers and their families. 


\section{SIGLAS}

AFPESP - Associação dos funcionários Públicos do Estado de São Paulo APEOESP - Sindicato dos Professores do Ensino Oficial do Estado de São Paulo AOPM - Associação dos Oficiais da Polícia Militar do estado de São Paulo

BITS - Bureau Internacional de Turismo Social

CLT - Consolidação das Leis do Trabalho

CPP - Centro do Professorado Paulista

FEQUIMFAR - Federação dos Químicos e Farmacêuticos

IBAMA - Instituo Brasileiro do meio Ambiente

IBGE - Instituo Brasileiro de Geografia e Estatística

OAB - Ordem dos Advogados do Brasil

RPPN - Reserva Particular do Patrimônio Nacional

SEBRAE - Serviço Brasileiro de Apoio às Micro e Pequenas Empresas

SESC - Serviço Social do Comércio

SNUC - Sistema Nacional de Unidades de Conservação

UC - Unidades de Conservação

URLs - Unidades Recreativas de Lazer 


\section{AGRADECIMENTOS}

Para uma empreitada dessas, de dissertação de mestrado, foram muitos aqueles que contribuíram para o desenrolar da pesquisa, e, portanto, são muitos os agradecimentos, ainda que certamente alguns acabem por serem esquecidos. Creio que a leitura a seguir é importante para a compreensão do desenrolar do trabalho, principalmente se considerarmos o contexto no qual vivemos, em uma nação que estudar e pesquisar não é uma das tarefas mais fáceis.

Em primeiro lugar agradeço ao Professor Doutor Eduardo Abdo Yázigi, meu orientador e amigo, resgatador do conceito de paisagem dentro da Geografia e que acreditou no meu trabalho sempre ligado a atores voltados para formas de movimentos sociais inseridos na apropriação do território.

Em segundo lugar a duas colegas de trabalho da Escola Estadual Oswaldo Aranha, minha diretora Maria Carolina Jerônimo que facilitou em muitas ocasiões minhas necessidades de pesquisa e à Professora Doutora Maria Eliza Miranda que dedicou muitas horas de discussões acaloradas a cerca dos diversos temas que a dissertação envolveu. Também agradeço aos alunos da referida escola que compreenderam minha necessidade de certas ausências inevitáveis, mas que por outro lado também os incentivou a buscarem "seu lugar ao sol” dentro da universidade pública.

Ao amigo e Professor Mestre Romeu Antônio de Araújo que me incentivou, inclusive financeiramente quando iniciava meus estudos na pós-graduação como aluno especial.

Agradeço ao pessoal da FEQUIMFAR em especial ao amigo e jornalista responsável Paulo de Tarso Pires Gracia e aos diretores Danilo, Jurandir, Sérgio, João, Edson, Silvam e à Maria Axiliadora do Sindicato dos Brinquedos que me oportunizaram muitas horas de entrevistas e inclusive de estadia em suas colônias de férias a mim e à minha família. 
Com relação à formatação do trabalho e outras diversas formas de auxílio agradeço aos amigos Luís Filipe, Ricardo, Kátia, Marcelo e Kimie.

À Secretaria da Educação do Governo do Estado de São Paulo que me oportunizou a bolsa-mestrado, sem a qual os custos de transporte, alimentação e aquisição de materiais de informática e livros se tornariam praticamente impossíveis de serem realizados.

E indiscutivelmente a todos os familiares, mas é claro que em especial à minha esposa Viviane e aos meus filhos Erick, Igor e Beatriz que em muitos momentos foram obrigados a conviverem sem a minha presença. 
SUMÁRIO

INTRODUÇÃO $\ldots \ldots \ldots \ldots \ldots \ldots \ldots \ldots \ldots \ldots \ldots \ldots \ldots \ldots \ldots \ldots \ldots \ldots \ldots$

Página

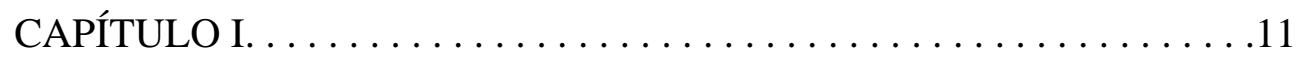

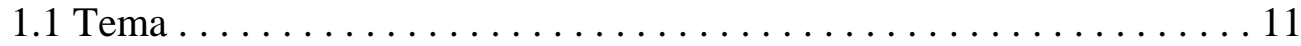

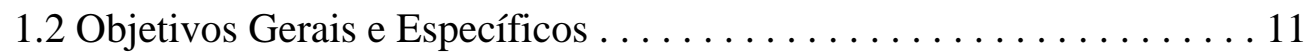

1.3 Justificativas . . . . . . . . . . . . . . . . . 13

1.3.1 O interesse pelo lazer, turismo social e as colônias de férias . . . . . .13

1.3.2 A Geografia e a organização do território para o turismo . . . . . . . . 18

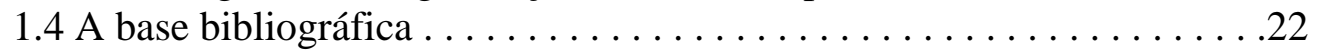

1.5 Questões de Método . . . . . . . . . . . . . . . . . . . . . 25

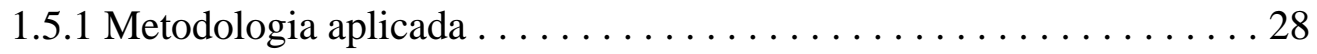

1.5.2 Trabalho Programado . . . . . . . . . . . . . . . . 29

CAPÍTULO 2: TURISMO SOCIAL E COLÔNIAS DE FÉRIAS . . . . . . . 31

2.1 Turismo Social - Considerações gerais . . . . . . . . . . . 31

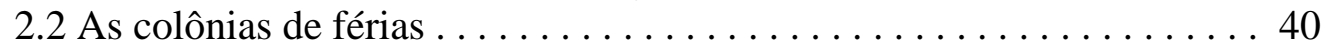

CAPÍTULO 3: AS INSTITUIÇÕES ANALISADAS . ........... 43

3.1 O Serviço Social do Comércio (SESC) ................. 44

3.2 A Associação dos Funcionários Públicos do Estado de São Paulo

(AFPESP) ................................ 48

3.3 Federação dos Químicos e Farmacêuticos do Estado de São Paulo

(FEQUIMFAR) ............................... 51

CAPÍTULO 4 : RELAÇÕES DE CUSTO E BENEFÍCIO ............ 56

CAPÍTULO 5: ASSOCIATIVISMO OU SINDICALISMO? ......... 68

CAPÍTULO 6. PLANEJAMENTO URBANO COM VISTAS

AO TURISMO - O CASO DO MUNICÍPIO DE PRAIA GRANDE. . . . . 90

7. CONCLUSÃO ................................. 99

8. BIBLIOGRAFIA CONSULTADA $\ldots \ldots \ldots \ldots \ldots \ldots \ldots \ldots \ldots \ldots \ldots \ldots$

9. ANEXOS ............................... 107 


\section{INTRODUÇÃO}

As questões sobre formas de apropriação e organização do espaço popular permearam meu trabalho de graduação individual. No caso, foram estudadas as relações de construção e re-construção de um conjunto habitacional voltado para classes de menor poder aquisitivo $^{1}$. De forma que aqui, no presente trabalho, direcionado à área de Geografia Humana e do Planejamento Urbano com vistas ao Turismo, foi possível, em grande medida, dar continuidade a essa discussão, sobre erros e acertos da apropriação e gestão do espaço envolvendo formas de movimentos sociais e instituições, como as associações e principalmente de sindicatos responsáveis pela gestão de colônias de férias de trabalhadores.

As colônias de férias são certamente uma forma de uso do espaço, especialmente do espaço turístico. São formas de uso que prescindem a organização de ações populares, ainda que contem com o auxílio e incentivo do Estado e que precisam ser melhor compreendidas no aspecto da sustentabilidade do território voltado para o turismo que considero aqui como um direito do trabalhador.

Quanto ao direito ao turismo deve-se destacar a criação da EMBRATUR (decreto lei n55, 1966), renomada pela lei 8181 de 1991 que em seu artigo I firma intenção de

\footnotetext{
${ }^{1}$ KARKLIS, Luís Roberto. Modo de vida em um conjunto habitacional, as relações na construção e reconstrução do espaço com participação comunitária: o caso do CDHU - Butantã D. Trabalho de Graduação Individual, FFLCH - USP, depto. de Geografia, 2000.
} 
democratizar o acesso ao turismo nacional, pela incorporação de diferentes segmentos populacionais de forma a contribuir para a elevação do bem estar das classes de menor poder aquisitivo.

A divisão da estrutura do trabalho foi feita da seguinte forma: no primeiro capítulo apresentamos os objetivos gerais e específicos, as justificativas juntamente com as delimitações e problematizações do tema, uma revisão da literatura pesquisada sobre princípios de método e da metodologia aplicada. No segundo capítulo uma discussão necessária sobre o conceito de Turismo Social uma vez que as colônias de férias de trabalhadores estão totalmente ligadas a essa modalidade de turismo. O terceiro capítulo apresenta uma análise das instituições pesquisadas, no caso o Serviço Social do Comércio (SESC), instituição modelo de referência para o turismo social, a Associação dos Funcionários Públicos do Estado de São Paulo (AFPESP), que apresenta ótima relação de custo benefício para o associado que busca seu lazer em colônias de férias e das colônias de sindicatos de trabalhadores principalmente ligadas à Federação dos Químicos e Farmacêuticos do Estado de São Paulo. O quarto capítulo pode ser entendido como um complemento do terceiro, uma vez que, é apresentado nele uma parte da nossa pesquisa de campo comparando custos e benefícios das colônias. O quinto capítulo traz uma discussão sobre a importância das associações como movimento social, mas essencialmente sobre o papel dos sindicatos junto ao fomento do turismo pra os trabalhadores, a discussão é pormenorizada com relação ao futuro do sindicalismo, sobre sua manutenção financeira e sua propensão como instituição renovada frente às novas transformações do capitalismo. No sexto capítulo apresentamos outra parte de nossa pesquisa de campo, diretamente ligada às questões da gestão/planejamento do território no município de Praia Grande no Estado de São Paulo, onde se encontra a maior concentração de colônias de féria de trabalhadores do mundo, também nesse capítulo fazemos a discussão sobre políticas públicas voltadas para o fomento de colônias de férias. Por fim, apresentamos no capítulo final a conclusão. 


\section{CAPÍTULO 1}

\subsection{Tema}

Estudo do papel das colônias de férias de sindicatos e associações no turismo social. Análise da estrutura, distribuição e organização de colônias de férias e as implicações dos modelos de lazer, turismo e gestão adotados por diferentes associações de trabalhadores. Focamos como recorte geográfico o Estado de São Paulo, onde verifica-se a maior concentração de colônias de férias do país, principalmente no litoral e nas regiões serranas. Na abordagem, analisamos a organização e estrutura de três instituições: o Serviço Social do Comércio, a Associação dos Funcionários Públicos do Estado de São Paulo e a Federação dos Químicos e Farmacêuticos.

\subsection{Objetivos gerais e específicos}

Contribuir para o estudo do planejamento urbano com vistas ao turismo e especificamente ao turismo social. A importância dentro da Geografia refere-se às questões da gestão do território, da proteção da paisagem e do meio ambiente. Pretende-se também dar referências às possíveis políticas públicas de incentivo às formas de associativismo e sindicalismo, que possam garantir um processo de democratização de turismo.

O que pretendemos como perspectiva de conclusão da dissertação é justamente demonstrar que associações e ou sindicatos já promovem experiências exitosas dentro de uma concepção mais ampla de turismo social, trazendo vantagens para os custos, tornado a 
viagem mais acessível ao trabalhador médio. Apesar de que, em sua grande maioria as colônias ainda são deficitárias, por outro lado podem contribuir para o meio ambiente e para o desenvolvimento de vida com qualidade do trabalhador e de sua família.

Com relação aos objetivos do trabalho ainda apresentamos outras preocupações, a saber:

- Uma conceituação mais ampla do termo Turismo Social

- Aportes teóricos para uma maior viabilização de gestão integrada dos serviços turísticos entre as associações, sindicatos e outras formas de organizações ligadas à gestão de colônias de férias.

- Identificar as melhores formas de incentivo e necessidades ao turismo social de colônias de férias.

- Identificar impactos sociais, econômicos e de planejamento territorial urbano/ambiental dos empreendimentos.

- Verificar a organização, estrutura e os modelos de gestão principalmente dos sindicatos no contexto da transformação pelas quais essas entidades atravessam no período contemporâneo.

- As associações ou os sindicatos seriam a melhor forma de modelo de gestão para colônias de trabalhadores?

- Analisar a trajetória das políticas públicas voltadas para o segmento bem como o que se espera de novas implementações para uma nação que pretenda democratizar o turismo 


\subsection{Justificativas}

1.3.1 O interesse pelo lazer, turismo social e as colônias de férias

Inicialmente entendemos a necessidade do lazer, já que as pausas ao trabalho são indispensáveis ao próprio trabalho para que este seja executado com melhor qualidade. Aliado a isso existe a importância de mudança de cotidiano, de práticas e da percepção de outras formas de ser e ver o mundo.

Há muito que as questões relacionadas ao lazer não podem mais ser considerado um problema menor para o trabalhador, de acordo com Dumazedier: "surgiu um tempo novo para seus atos e sonhos. Esse tempo é ocupado por atividades reais ou possíveis, cada vez mais atraentes. São resultados da indústria do lazer que incentivou o desenvolvimento das associações e grupos que procuram satisfazer suas predileções”².

Para Dumazedier as concepções sobre o trabalho sempre mereceram destaque. Como para Max Weber: "O trabalho justifica o ganho e toda a atividade inútil à sociedade é uma atividade menor” ou para Marx: “O trabalho é a essência do homem”. De certa forma, por esta visão do trabalho, tinha-se em contrapartida a concepção de ociosidade do lazer. O lazer é definido, nos dias de hoje, sobretudo, por oposição ao conjunto das necessidades e obrigações da vida cotidiana. O lazer não tem significado qualquer em si mesmo, só é compreendido pelas pessoas que o praticam dentro de uma dialética da vida cotidiana, na qual todos os elementos se ligam entre si e reagem uns sobre os outros. Citando Lefebvre, Dumazedier diz que o autor esboçou uma análise das alienações do homem contemporâneo, que o levam a um sentimento de privação e necessidade de ruptura com o universo cotidiano ${ }^{3}$.

Ficamos com a seguinte definição de lazer: "O lazer é um conjunto de ocupações às quais o indivíduo pode entregar-se de livre vontade, seja para repousar seja para divertir-se, recrear-se e entreter-se ou, ainda para desenvolver sua informação ou formação

\footnotetext{
${ }^{2}$ Dumazedier, Lazer e Cultura Popular, p. 24.

${ }^{3}$ Idem, p.33.
} 
desinteressada, sua participação social voluntária ou sua livre capacidade criadora após livrar-se ou desembaraçar-se das obrigações profissionais, familiares e sociais” ${ }^{4}$.

Há de se mencionar sobre as contradições entre trabalho e lazer, o lazer desperta a necessidade de alargar as fontes de informação, sem qualquer ligação com o meio de trabalho. A prática de lazer pode ser dedicada ao estudo, oferecendo novas possibilidades para reorganizações mentais, em cada novo período da vida do indivíduo e da civilização. Pelo contrário também pode se constituir em um meio voltado sobre si próprio, fechado às correntes externas e indiferente ao desenvolvimento da participação ativa dos membros na vida cultural de seu tempo.

Certas ambigüidades podem ser provocadas pela prática do lazer, isto é; ao mesmo tempo em que possa ocorrer uma restauração da força de trabalho, pode surgir também um gosto pela ociosidade. A prática das atividades recreativas muitas vezes termina numa negação a qualquer tipo de compromisso profissional ou sindical, dissolvendo o sentido de responsabilidade profissional e social.

Também existem as dificuldades de empresários e líderes sindicais em despertar o interesse do trabalhador sobre os problemas da empresa ou do mundo do trabalho. Dumazedier atesta que no exemplo francês, boa parcela dos trabalhadores não se interessavam por férias culturais e não participavam da vida das associações ${ }^{5}$. O trabalho só será humano se permitir ou suscitar um lazer humano, porém o lazer que não passar de uma simples evasão do trabalho, de uma fundamental falta de interesse pelos problemas técnicos e sociais do trabalho, só será uma falsa solução dos problemas da civilização industrial. Não é possível também tratar separadamente e, cada um de seu lado, os problemas próprios do lazer e os que pertencem ao trabalho.

As contradições sobre o tema continuam, torna-se necessário ampliar a possibilidade de medidas sociais que visam ao incentivo do turismo de massa, são alguns exemplos a

\footnotetext{
${ }^{4}$ Idem, p.34.

${ }^{5}$ Idem, p.110.
} 
poupança de férias e as viagens coletivas. Por outro lado há os problemas ligados à distribuição das saídas de férias durante o ano, levantados por Dumazedier , parece coisa de difícil solução, as férias escolares são o grande exemplo. A questão é que não há um aproveitamento do equipamento turístico durante o ano de trabalho, e, ao contrário, nas férias os equipamentos são insuficientes, os preços são elevados, há uma especulação imobiliária e até segregação ${ }^{6}$.

Uma das proposições centrais de Dumazedier refere-se às atitudes ativas no lazer:

“O problema central de uma civilização do lazer, reside na possibilidade de suscitar atitudes ativas, durante a utilização do tempo livre”, ser desalienante, devemos compreender a "necessidade de definir normas de lazer que poderão propiciar o desenvolvimento do homem na civilização contemporânea” e evitar “o perigo da passividade”. “A atividade de lazer em si mesma não é passiva ou ativa, mas o será pela atitude que o indivíduo assumir com relação às atividades decorrentes do próprio lazer”, “a atitude ativa implica, ao menos periodicamente, uma participação consciente e voluntária na vida social” ${ }^{7}$.

Ser ativo opõe-se à submissão às práticas rotineiras, às imagens esteriotipadas e às idéias pré-concebidas de determinado meio social. Dumazedier alerta que isso "não se trata de um exaustivo esforço de auto-educação permanente, mas cada indivíduo passará a prestar mais atenção ao justo equilíbrio entre as atividades de recuperação, recreação e desenvolvimento, determinado pelas situações da vida cotidiana”. "O tempo do lazer apresenta-se como o sustentáculo de uma atitude que não será considerada marginal, mas mediadora entre a cultura de uma sociedade ou de seu grupo e as reações de um indivíduo às situações da vida cotidiana”, é a possibilidade de uma ruptura da rotina para as massas.

Conferir importância ao lazer é compreender um processo de conseqüência lógica da revolução democrática e industrial, não conferir importância ao lazer é comprometer

\footnotetext{
${ }^{6}$ Idem, p.155.

${ }^{7}$ Idem, p. 256 e 257.
} 
soluções de problemas como o consumo desenfreado e a padronização.

Como justificativa social para o estudo das colônias dentro do seio do Turismo Social fazemos uso das idéias de Yázigi: "Se vivêssemos numa sociedade com iguais oportunidades, isto é, se a receita familiar fosse suficientemente elevada, não seria necessário, absolutamente, priorizar o turismo social” ${ }^{\text {. }}$. Sem dúvida caso vivêssemos numa sociedade onde todos tivessem de pagar contas normais, isto não seria necessário. Porém fica um questionamento, o que seriam "contas normais" considerando, por exemplo, uma família que planeje sua viagem juntamente com amigos que possam locar uma pousada ou casa de veraneio, seria arcar com contas normais? Os custos de um turismo social teriam de ser razoavelmente mais vantajosos, o que ainda não é isto que represente, pois certos estratos sociais não podem nem mesmo arcar com os custos de uma viagem e hospedagem baseadas em uma programação de turismo social. De qualquer forma sabemos não haver tantas ofertas no mercado facilitando a regulação do turismo social, neste caso, a idéia de inclusão é bastante cabível e o Estado pode aparecer como agente articulador.

Talvez seja justamente o formato das colônias de férias de sindicatos e associações serem um exemplo de novas organizações que se espera de um turismo democrático. Como destaca Yázigi, associações podem negociar melhores preços de uma viagem, desde o transporte até a hospedagem, barateando os custos. As associações podem e devem, em geral, proporcionar diversos benefícios a seus associados, "uma modalidade de socialização possível dentro do sistema capitalista”, ainda que passíveis de serem corrompidas pelos “interesses pessoais, dos que manipulam compra e vendas", absolutamente um risco necessário uma vez que vivemos um eterno embate entre democracia e corrupção ${ }^{9}$.

Pensando na proteção da paisagem e do ambiente a verticalização torna-se indispensável. Yázigi discute sobre o mito da habitação horizontal estar de acordo com a natureza. Em uma área de $14.000 \mathrm{~m}^{2}$ destinada à ocupação de cerca de 25 famílias de veranistas poderia tornar-se para no mínimo dez vezes mais pessoas, opção para áreas de

\footnotetext{
${ }^{8}$ Por uma política de turismo social, p.32.

${ }^{9}$ Idem, p.44.
} 
menor comprometimento da paisagem, ainda que se leve em conta uma gabaritagem de edifícios entre quatro ou seis andares. "É só com o sacrifício de parte do território que se consegue salvar o mais substancial da totalidade”(193) ${ }^{10}$.

O que Yázigi assinala muito bem é que em matéria de turismo para os mais pobres e mesmo para outras classes sociais o turismo social torna-se uma grande solução, destacando-se neste caso as colônias de férias, que podem alojar milhares de pessoas ao longo do ano, “poupando a urbanização em centenas de milhares de quilômetros no litoral e na montanha. Só por isto mereceriam ser objetos de altas compensações municipais: sua concentração, poupando território, presta serviço ao interesse coletivo”11.

Com relação à hipótese o trabalho irá procurar demonstrar algumas possibilidades.

Em primeiro lugar é fato que as colônias de férias são um meio de hospedagem acessível para as classes sociais menos favorecidas, sobretudo se considerarmos valores de estadia em pousadas ou aluguel de casas de veraneio, no entanto, as classes sociais realmente menos favorecidas, ainda não apresentam condições reais financeiras de poder usufruir dessa forma de turismo, salvo algumas exceções. Isso porque os custos de hospedagem e transporte ainda pesam sobremaneira nos rendimentos do trabalhador mais pobre.

Por outro lado as colônias de férias já são uma realidade de turismo sustentável, seja economicamente ou ambientalmente falando. O sucesso dessa modalidade de hospedagem está diretamente ligado às associações e aos sindicatos. Mas, no geral, os sindicatos oferecem custos até 50\% mais baratos do que organizações bem estruturadas como o SESC e a AFPESP, instituições que na verdade atendem principalmente pessoas da classe média. São instituições que inclusive apresentam soluções de alto padrão de ocupação do espaço, com soluções de arquitetura e paisagismo bem adaptadas às paisagens das cidades, podendo vir a ser constituídas como verdadeiros patrimônios da cidade, como, por exemplo, o caso

\footnotetext{
${ }^{10}$ A alma do lugar, p.193.

${ }^{11}$ Idem, p.193.
} 
do SESC - Bertioga - SP.

O mesmo já não ocorre com as colônias de sindicatos da Praia Grande - SP, como será demonstrado no estudo de caso, foram feitas sem muitas preocupações urbanísticas e poderiam fazer justiça a um turismo social no seu conceito mais amplo. Isso porque as instituições preocupadas com um conceito mais amplo de lazer sempre apresentam em sua programação atividades recreativas e educacionais, geralmente contam com bibliotecas e até mesmo cybercafés.

Mas, o sindicalismo, como também será discutido, tem passado por diversas mudanças na sua forma de atuação, e uma delas refere-se ao trabalho dessas organizações em atenderem às necessidades de lazer do trabalhador e sua família, certamente, e procurei defender isto, uma necessidade imperativa para os tempos atuais.

Para o futuro, o sucesso das colônias de férias estará cada vez mais agregado ao empenho das formas de associativismo e sindicalismo. Como objetivo amplo, cabe a este presente trabalho apresentar formas e propostas de planejamento, seja no âmbito organizacional e administrativo, seja no âmbito do planejamento urbano do turismo e ambiental, como forma de orientação ou mesmo simples consulta para aqueles que trabalham ou pretendam ser empreendedores dessa forma de ocupação do espaço.

\subsubsection{A Geografia e a organização do território para o turismo}

John Naisbitt em seu Paradoxo Global (1999) analisa a globalização da maior indústria mundial: "No paradoxo global, a maior indústria é impelida, como nenhuma outra, pelas decisões dos indivíduos. Os protagonistas menores decidem”" ${ }^{\text {"2 }}$ Entende que o turismo é o setor que mais contribui para a economia mundial, sendo um dos maiores empregadores, apesar disso procura explicações para a atenção tão pequena dos governantes e artífices dos acordos comerciais internacionais. Se por um lado as análises de Naisbitt são focadas no

\footnotetext{
${ }^{12}$ Naisbbit, p.155.
} 
desenvolvimento do turismo internacional, por outro lado, ele afirma que o setor que mais irá crescer é o do turismo doméstico.

De acordo com Castro ${ }^{13}$ o interesse epistêmico do geógrafo pela dimensão espacial do turismo data desde o século XIX. Em sua tese, a autora nos apresenta uma diversidade de visões de geógrafos e outros estudiosos de áreas afins sobre o tema, em uma abordagem que leva em conta todo o processo de evolução da ciência geográfica e seus pontos de contato com o estudo do turismo.

Nas raízes da abordagem geográfica do turismo até a primeira metade do século XX, ocorreu uma evolução na busca de se entender o fenômeno turístico em sua origem e processo, como fator da transformação da paisagem cultural, baseado no método indutivo da observação, comparação, classificação, generalizações e explicações. Após esse período a Nova Geografia, de influência neopositivista, contribui com os estudos de regularidade da distribuição do fenômeno turístico em dimensão espacial e também com relação de se pensar o processo de urbanização turística. A partir dos anos 70 com a abordagem Crítica da Geografia "afirma-se a tendência à abordagem pluriparadigmática na produção do conhecimento na abordagem geográfica do turismo” ${ }^{14}$.

Silva (2003) destaca como marco da importância do turismo dentro da Geografia as idéias do geógrafo Chistaller:“a perspectiva locacional do turismo ao apontar para sua relação típica com as periferias de áreas centrais densamente povoadas, já que o turista prefere, como princípio geral, conhecer áreas diferentes e distantes de seu habitat. Por conseguinte, os fatores locacionais para o desenvolvimento do turismo estão relacionados com a existência de ambientes e culturas diferenciadas. Isto ressalta a geograficidade do turismo, ou seja, o turismo aposta nas diferenças locais e regionais tão valorizado pela Geografia”,

O que mais nos interessa é que, apesar de ainda haver uma sistematização insuficiente

\footnotetext{
${ }^{13}$ O lugar do turismo na ciência geográfica, Tese de Doutorado, USP, FFLCH, 2006.

${ }^{14}$ Idem, p. 18 e 19.

${ }^{15}$ Turismo comunitário e responsabilidade sócio-ambiental, 2003, p.21.
} 
do estudo da geografia do turismo, essa evoluiu ao longo do século XX, buscando explicar os impactos espaciais e analisar suas causas geográficas para uma melhor compreensão das relações homem-meio natural, inclusive ao analisar o comportamento dos diferentes grupos de turistas, das instalações turísticas e nos processos de organização espacial. Para Castro esses estudos geraram "referências essenciais para a elaboração de novas postulações sobre o espaço turístico, além de oferecer subsídios às políticas de ordenamento, planejamento e gestão da atividade”16.

Ainda de acordo com Castro, o que é bastante recorrente nos estudos de geografia do turismo, refere-se a diversos fatores como a falta de controle do crescimento dos lugares turístificados, da destruição dos ecossistemas, do uso inadequado do solo e da água, das políticas públicas inadequadas, das políticas de ordenamento, planejamento, gestão e sustentabilidade dos espaços turísticos ${ }^{17}$.

Outras proposições merecem destaque com relação à melhoria da organização do espaço turístico, é o caso da inserção da identidade do lugar. Essa é a visão de Yázigi (2001), que por um lado dá destaque ao entendimento do mundo físico "supondo que a orientação conservacionista venha a ser o substrato mais plausível da reconstrução da identidade turística...”.E por outro lado considera o poder da arquitetura e do urbanismo como poderosos “definidores dos modos de vida e dos aspectos paisagísticos do lugar”, gerando uma "reflexão sobre como o meio poderia sugerir uma certa ordem espacial, sem entretanto, cair no desacreditado determinismo geográfico”18.

Com Silveira ${ }^{19}$ (2002), observamos que as principais características do turismo no atual contexto da globalização, sobretudo com relação às questões de desenvolvimento sustentável e de planejamento territorial, exigem uma análise do atual impacto das políticas públicas para planejamento territorial do turismo em escala federal e precisamente estadual.

\footnotetext{
${ }^{16}$ O lugar do turismo na ciência geográfica, Tese de Doutorado, USP, FFLCH, 2006, p. 20.

${ }^{17}$ Idem, p. 36.

${ }^{18}$ A alma do lugar, p. 20 e 21.

${ }^{19}$ Turismo, políticas de ordenamento territorial e desenvolvimento. Um foco no estado do Paraná no contexto regional.
} 
O já notável crescimento do turismo em escala mundial tem despertado maior atenção de governantes em formular políticas públicas de desenvolvimento, inclusive nos países em desenvolvimento onde a atividade é setor estratégico da economia. No Brasil é a partir de 1990 com a Política Nacional de Turismo, que algumas ações passam a contribuir para o desenvolvimento do turismo, basicamente na implantação de infra-estrutura para a atração de investimentos privados e na formação de mão-de-obra para o setor. Ao analisar os impactos desta política sobre o estado do Paraná, Silveira propõe um estudo de interfaces aos elementos de recorrência nacional, continental e global, em que pese a necessidade de compreender não apenas o funcionamento econômico, mas, a idéia de sustentabilidade e das transformações territoriais, que tanto interessam à Geografia, causadas pela expansão da atividade turística ${ }^{20}$.

A tendência de expansão do turismo no espaço mundial nas últimas décadas é bastante evidenciada de acordo com o estudo de muitos autores citados por Silveira, porém a sua conceituação ainda é objeto de muita discussão:

“fortemente conectado ao processo de globalização, o turismo se transformou em uma atividade multidimensional e complexa, que implica numa teia de relações em muitas esferas da vida social e que, por isso, é visto sob vários ângulos e definido de várias formas”. Dentro do debate a questão mais importante deve ser: Qual é o impacto do turismo na sociedade contemporânea? Os significados podem ser muitos, a busca pelo diferente, uma relação econômica e ou cultural, ou mesmo uma nova forma de colonialismo provocando transformação cultural, degradação ambiental e mesmo aumento da exploração. A lógica do turismo corresponderia à mesma lógica da globalização da economia, corporações transnacionais seriam os grandes agentes desta mundialização do turismo ${ }^{21}$.

Em cerca de pouco mais de cem anos o processo de expansão geográfico do turismo englobou e tem englobado as mais remotas áreas de todo o planeta. De qualquer forma

\footnotetext{
${ }^{20}$ Idem, p.8.

${ }^{21}$ Idem, p.22.
} 
apesar da expansão para os países periféricos ou em desenvolvimento a concentração das “zonas geoturísticas receptoras” permanecem esmagadoramente na Europa e na América do Norte. Por outro lado há evidências de grande crescimento do turismo doméstico nos países desenvolvidos e em desenvolvimento. E é neste aspecto que nos interessa, o turismo doméstico é fundamentalmente aquele ligado ao turismo social e de práticas organizacionais de sindicatos, grupos e outras formas, que surgem como hipótese alternativa ao "sistema turístico multinacional" conceituado por Cazes, citado por Silveira $^{22}$.

Devemos destacar a necessidade de compreendermos qual o grau de importância das colônias para os governos e para o meio empresarial. Descobrir se há preocupações e mais do que isso, se há ações voltadas para a melhoria deste tipo de turismo. Neste contexto deveremos identificar as organizações ou instituições que se preocupam com o treinamento, segurança, administração e educação ambiental voltadas ao bom funcionamento das colônias e logicamente de um turismo sustentável.

\subsection{A base bibliográfica}

As referências bibliográficas utilizadas revelam o caráter interdisciplinar do trabalho, bebendo no conhecimento geográfico, histórico, sociológico e em menor grau da administração, da economia e da urbanização é que foi possível estabelecermos relações e conexões adquiridas durante o processo de construção da dissertação.

Substancial bibliografia e fundamentos foram utilizados da disciplina Trabalho, Sindicato e Globalização cursada no departamento de Sociologia junto ao professor Iram Jácome Rodrigues. A discussão principal proposta durante o curso refere-se às tendências do sindicalismo para o século XXI sobre sua discutida crise e seu futuro, sobre as novas

formas de relações de trabalho e de novas formas de organização dos trabalhadores, que acabam refletindo fundamentalmente sobre as condições de vida do trabalhador e sua família.

\footnotetext{
${ }^{22}$ Idem, p.25.
} 
Igualmente importante foi necessário desenvolver a discussão sobre a formação do sindicalismo brasileiro e sua dependência do Estado. Quanto à situação do sindicalismo brasileiro no momento foi-nos apresentado uma certa estabilidade após um período de refluxo. A partir da fase designada como novo sindicalismo, as funções dos sindicatos passam a incorporar às lutas salariais e direitos trabalhistas outras formas de melhoria das condições de vida do trabalhador e de sua família.

Foi bastante relevante compreender sobre o certo recrudescimento nas taxas de sindicalização, pois comprometem diretamente os recursos de manutenção das colônias de férias. Nos novos tempos alguns sindicatos vem superando a crise ao contrário de outros. Apesar de todo esse quadro de transformações no mundo do sindicalismo fica-nos a reflexão e proposição de serem os sindicatos organizações preparadas para a gestão de colônias de férias, ainda que alguns autores discordem, fato que é tratado no decorrer da pesquisa.

Com o curso da professora Neli Aparecida de Mello, Políticas ambientais e estratégias territoriais de desenvolvimento, somou-se a necessidade de se pensar uma construção mais adequada sobre políticas ambientais regionais e locais, bem como sobre a importância do desenvolvimento e aplicabilidade dos planos diretores e; além disso, repensar sobre uma Política Nacional de Turismo, notadamente voltada para o turismo social.

A disciplina proporcionou a discussão da chamada “redução” do Estado, quando esse na verdade ainda se apresenta como o principal e essencial fomentador e regulador de políticas públicas, inclusive não apenas para o meio ambiente como em outras áreas de muita relevância ligadas ao tema estudado.

Um exemplo sobre a importante ação do Estado são as Unidades de Conservação e dentro delas as Reservas Particulares de Proteção Nacional, são modelos de gestão do território que permitem a prática do que podemos chamar de turismo sustentável, proteção/conservação e geração de empregos, apresentando-se, portanto, como possíveis horizontes de desenvolvimento. 
De acordo com Neli Mello ${ }^{23}$ (1986), há no entanto ainda muitos problemas a serem solucionados para a manutenção e ampliação das Unidades de Conservação. São problemas como orçamentos reduzidos, a escolha de modelos preventivos de ordenamento, a pressão pela participação maior de competitividade brasileira no mercado mundial e o que nos parece o maior desafio; como ampliar para uma maior parcela da sociedade a utilizar os instrumentos de políticas ambientais. E ao que tudo indica, essa última questão não deve ser alterada em curto prazo, os novos investimentos governamentais podem colocar em risco até mesmo as áreas já protegidas.

Ainda com relação às políticas públicas de ordenamento do território, foi possível fazermos um cruzamento de políticas: ordenamento territorial, proteção ambiental e turismo social. Com relação à última, ampliou-nos a percepção a respeito de como os governos desenvolveram e fizeram usos de legislações para o turismo do trabalhador. Foram leis, criações de subsídios, doações de terrenos que durante a pesquisa procurou-se levantar.

Como tese, ampliou-se também a necessidade de pensar em uma política pública voltada para o turismo social enriquecendo-o conceitualmente para uma evolução de sustentabilidade sócio-ambiental, pensar em um certo padrão e fomentar formas mais diretas e claras de subsídios, uma vez que há concretas possibilidades de retorno para o meio ambiente e para a sociedade de uma forma geral.

Sobre lazer e turismo social as referências principais foram extraídas de Dumazedier, Yázigi, Baptistela e Almeida, além dos materiais institucionais do SESC, da AFPESP e do BITS. Também utilizamos material institucional do Ministério do Turismo e da Prefeitura do Município de Praia Grande, inclusive do plano diretor.

As bibliotecas visitadas foram as seguintes:

- Faculdade de Filosofia Letras e Ciências Humanas - USP, nas áreas de

\footnotetext{
${ }^{23}$ Contradições territoriais, signos do modelo aplicado na Amazônia.
} 
Geografia(planejamento, turismo e meio ambiente), História (principalmente sobre leis ligadas ao tema) e Sociologia (lazer e trabalho).

- Escola de Comunicação e Artes - USP (lazer, planejamento, marketing e turismo)

- Faculdade de Economia e Administração - USP (marketing, administração e turismo).

- Biblioteca da Associação dos Funcionários Públicos do Estado de São Paulo.

- Biblioteca do Serviço Social do Comércio.

- Biblioteca da Prefeitura Municipal de Praia Grande.

Imprensa:

- Jornal da Federação dos Químicos e Farmacêuticos.

- Jornal da Associação dos Funcionários Públicos do estado de São Paulo.

- Folha de São Paulo.

Sítios:

- Prefeituras municipais do Estado de São Paulo, sempre com relação às áreas de turismo e planejamento urbano e ambiental.

- Sobre turismo social em outros países como o México e a França, inclusive do Boreau Internacional de Turismo Social.

- Ministério do Turismo

- Ministério do Meio Ambiente

1.5 Questões de método

No curso Questões de método em Geografia, ministrado pela professora Maria Laura da Silveira, foram feitas certas reflexões à cerca de atuais conceitos, categorias e esquemas possíveis sobre teoria e método em Geografia. Em certa medida discutiu-se sobre a passagem de uma epistemologia geral a uma epistemologia particular, notadamente voltada ao período atual. 
Tornou-se consenso que no período da globalização a construção de conceitos válidos para um lugar e seu tempo tornam-se cada vez mais complexas. O desafio é grande na medida em que buscamos uma teoria adaptada ao momento, que se pretenda universal servindo imperfeitamente a todos os lugares, um esforço de interpretação totalizadora partindo-se de um jogo, do universal ao particular e vice-versa.

A necessidade de se elaborar uma teoria específica exige uma visão de mundo privilegiando elementos interdisciplinares, portanto, a coerência externa de uma disciplina exige a produção de um saber distinto de outras disciplinas ao mesmo tempo que seja um complemento, enquanto que a coerência interna é dada a partir de categorias analíticas que dêem conta do saber, permitindo a produção de esquemas operacionais. Justamente a interdisciplinaridade permeou nossa pesquisa em diversos momentos, no campo da sociologia, da história, do turismo, da saúde, da arquitetura e do urbanismo.

Silveira nos exemplifica sobre a tarefa árdua do pesquisador em escolher variáveischaves de um estudo em questão; ocorre que as variáveis determinantes vem tornando-se dominantes, “ciência, técnica, informação e finanças atingem, de forma mais ou menos visível, todas as pessoas, atividades e lugares” (Silveira, 2005, p.9), ora, certamente o lazer e o turismo não estão fora dessa questão quando olhamos que a rigor apenas recentemente passou-se a discutir sobre a democratização do turismo.

Nosso problema central: como aplicar um método para um estudo de Geografia envolvendo a “disciplina turismo”? De acordo com Dencker a ciência do turismo está em desenvolvimento, não forma um corpo de conhecimentos independentes. No mundo acadêmico, as teses sobre o assunto, estão distribuídas em estudos de natureza multi ou interdisciplinar ${ }^{24}$. Por conta dessa multidisciplinaridade surgem alguns problemas como as investigações que trabalham apenas dentro dos limites de suas disciplinas de forma fragmentada, levando os pesquisadores buscarem a transdiciplinaridade.

\footnotetext{
${ }^{24}$ DENCKER, Ada de Freitas Maneti. Métodos e técnicas de pesquisa em turismo. São Paulo ed. Futura 1998.
} 
A questão dos contornos de um novo paradigma também apareceu em nosso trabalho: "Na atividade turística, essa evolução dos paradigmas aponta para uma substituição do turismo de massa por um tipo mais brando, pra a busca de um desenvolvimento autosustentável”, na busca de um paradigma "qualitativo" 25.

Com referência à especificidade de um método em Geografia apoiamo-nos no debate sobre a modernidade travado por Gomes, cujo esforço atual é o de criar elementos únicos em oposição à produção de objetos em série. A idéia é negar o universalismo e as generalizações. A hermenêutica estaria sendo re-introduzida: "o horizonte da hermenêutica abriria espaço para um conhecimento não-hierarquizado, menos pretensioso em suas generalizações e mais atento às especificidades, pois não está comprometido por uma ordem lógica, estável e geral” ${ }^{26}$.

Na geografia o reflexo desse debate aponta para a constante transformação e ou discussão metodológica da disciplina ao mesmo tempo em que indica sua própria expressão de modernidade. De acordo com Gomes "esses debates foram freqüentemente postos em termos de uma geografia geral vesus uma geografia regional, ou de um discurso das leis versus a descrição, ou sobre o lugar do único versus o universal, ou ainda, sobre a relação da linguagem científica e os conceitos geográficos”27.

Da escola vidaliana, retiramos que "a especificidade da ação humana, com relação à dos outros elementos, vem de sua maior capacidade de transformação. Ela tem um papel central na organização do meio. Enquanto que, para o determinismo, o homem era apenas um elemento entre outros, com Vidal, ele se faz mestre dos outros, pois se adapta à natureza e a transforma em seu próprio benefício”. ${ }^{28}$. Apoiamo-nos também em três proposições essenciais: observação, comparação e conclusão. Com relação às comparações procuramos encontrar nos casos particulares indícios de regularidades, de forma que foi possível buscar

\footnotetext{
${ }^{25}$ Ibdem, p.35.

${ }^{26}$ GOMES, Paulo César da Costa. Geografia e Modernidade. Ed. Bertrand Brasil, Rio de Janeiro, 2003, p.34.

${ }^{27}$ Ibdem, p.45.

${ }^{28}$ Ibdem, p.200.
} 
agrupamentos, classificá-los e subdividi-los.

Pensando em termos de uma renovação crítica desenvolvemos uma empatia pessoal com o objeto calcado inclusive na busca de uma explicação para as paisagens culturais. Apostamos que em grande medida observamos um fenômeno de caráter singular e conseqüentemente de localização única, ainda que possam ser encontradas generalizações é indiscutível a importância do estatuto da singularidade. Não pudemos evidentemente nos calcar apenas no levantamento e tratamento de dados, mas questionar as relações de ordem social, em busca de um saber para uma transformação social, sempre calado na elhor das tradições da Geografia com pesquisa de campo.

Como comprovação de certas teorias, podemos afirmar que a obra de Christaller sobre lugares centrais se aplica em nosso estudo de caso, a rede urbana funcional que se desenvolveu no Estado de São Paulo articulou e tem articulado produtos e serviços distintos, no caso a procura turística "pelo diferente” levou mesmo a classe trabalhadora ou de poucos recursos a buscar sua viagem no litoral ou na montanha ${ }^{29}$.

Resta saber se a Geografia pode existir como ciência do espaço com autonomia, ou se ela deverá se curvar às determinações sociológicas e à causalidade histórica. Ou concordar com Gomes quando diz que não existe mais a crença em uma via metodológica única, que será aquela da verdadeira geografia, e se reconhece a importância e a riqueza de outras condutas possíveis para a geografia. ${ }^{30}$

\subsubsection{Metodologia aplicada}

A proposição de fazermos uma dissertação com o tema colônias de férias levou-nos em um primeiro momento pesquisarmos a amplitude dessa modalidade hoteleira em nível nacional. No caso a fonte requerida foi o Ministério do Turismo e foi identificado a maior concentração na região Sudeste e no Estado de São Paulo. Concentramo-nos então a fazer o

\footnotetext{
${ }^{29}$ Ibdem, p.255.

${ }^{30}$ Ibdem, p.303.
} 
levantamento de dados referentes a essa unidade da federação.

Foram realizadas visitações aos escritórios da AFPESP, da FEQUIMFAR e do SESC, onde foram realizadas diversas entrevistas e consultas, algumas delas gravadas, outras relatadas e outras ainda de cunho informal. Os entrevistados foram principalmente líderes sindicais envolvidos com a gestão das colônias e funcionários das instituições ligados aos departamentos de turismo e comunicação ${ }^{31}$.

Foram cinco visitas ao município de Praia Grande, no litoral, entre 2005 e 2007, as visitas envolveram a estadia do pesquisador e de sua família duas vezes na colônia do Sindicato dos Brinquedos e uma vez no Sindicato dos Borracheiros, mas também em visita na colônia da Federação dos Químicos.

Em duas dessas visitas foi possível participar como observador do projeto de conscientização organizado pela FEQUIMFAR intitulado "Verão sem AIDS”. Também no mesmo período ocorreram visitações à Prefeitura do município de Praia Grande. Como parte do trabalho de campo foi desenvolvido um trabalho programado abaixo descrito.

\subsubsection{Trabalho programado}

O trabalho foi proposto pela orientação a ser apresentado no $1^{\circ}$ semestre de 2006 . O tema central desenvolvido foi com relação aos custos de uma colônia de férias e acabou propiciando dados que foram incluídos no capítulo sobre custos e benefícios.

O levantamento principal foi feito na colônia de férias do Sindicato dos Fabricantes de Brinquedos e Instrumentos Musicais, no município de Praia Grande nas duas primeiras semanas de janeiro de 2006. Consistiu no cruzamento de dados entre receitas e custos.

31 . Sindicalistas entrevistados ligados `a FEQUIMFAR:

Presidente: Danilo Pereira da Silva, segundo vice-presidente: Maria Auxiliadora dos Santos, tesoureiro geral: Jurandir Pedro de Souza, secretário geral: Sérgio Luiz Leite, primeiro secretário: Edson Dias Bicalho, suplente: João Donizeti Scaboli. 
Quanto aos custos foram feitos os cálculos sobre gastos com salários, alimentação dos hóspedes, higienização e manutenção. Das receitas foram extraídos os valores cobrados pela estadia e com os gastos no restaurante e no bar.

Para a confecção dos mapas utilizamos as fontes de diversos sítios de Prefeituras do Estado de São Paulo, além de ferramentas como Google e Guia de ruas, nesse caso o levantamento poderia ser mais completo, pois infelizmente algumas prefeituras e mesmo órgãos estaduais e federais não retornavam nossos questionamentos via correio eletrônico, seja por falta de prontidão no atendimento ou mesmo da não disponibilização das informações como quantidades de colônias nos municípios e seus respectivos valores de estadia.

Entendemos que a pesquisa poderia ser mais completa caso pudéssemos realizar entrevistas com os usuários envolvendo questões como número de vezes de viagens, quantidade de acompanhantes, aspirações e perspectivas durante a estadia e sem dúvida sobre os diversos aspectos que indicassem níveis de qualidade, o que nos ajudaria a pensarmos em uma forma de ISO para a modalidade hoteleira colônia de férias. 


\section{CAPÍTULO 2: TURISMO SOCIAL E COLÔNIAS DE FÉRIAS}

\subsection{Turismo Social - Considerações gerais}

Neste capítulo é apresentada a visão de alguns autores sobre as origens do turismo social, bem como sobre a discussão de seu conceito, que, como poderemos notar, ainda está envolto por algumas incertezas muito ligadas à sua função. Também se procurou encontrar uma classificação para as colônias de férias de trabalhadores, de acordo com suas origens e estrutura organizacional, forma de gestão e público alvo. É importante destacar que as colônias de férias são um meio de hospedagem, ou seja, de turismo receptivo, que podem ser oferecidas através do turismo social, por isso a necessidade de se compreender melhor de qual turismo social pode se falar quando estudamos as colônias de férias.

A origem do Turismo Social desde o início está ligada ao movimento trabalhista e de suas relações com o Estado, continuando a ser dessa forma na Europa e também no Brasil, pois de alguma forma sempre há algum envolvimento do poder público, seja com relação ao transporte e ou à estadia, inclusive no que se refere ao fomento da criação e desenvolvimento de colônias de férias.

Foi a Alemanha o primeiro país a desenvolver viagens para trabalhadores fortemente 
inseridos em um contexto político-ideológico. No final dos anos 20 sindicatos organizados independentes passaram a organizar viagens de trabalhadores, imitando a agência católica Rotala. Com Hitler no poder o turismo passa a ser subordinado ao Estado e uma agência passa a ser responsável pelas viagens, “que se revelariam excelentes instrumentos de propagação da ideologia nacional-socialista que, em resumo, significava 'conservar a paz social mediante a supressão e a harmonização das estruturas, conflitos e contrastes sociais em uma comunidade popular nacional-socialista” (ALMEIDA, 2001, p.53) ${ }^{32}$.

Foram mais de cinco milhões de viajantes em 1935, por diversos meios de transporte e geralmente alojados em domicílios particulares, o Estado pretendia com essas viagens “fortalecer o amor pela grande pátria”. Segundo Almeida, citando Knebel, (1974) “foi um importante meio para produzir o aburguesamento de uma classe social infraconsiderada, que representava a massa da população. De todas as atividades burguesas do tempo livre o viajar ocupava as cotas mais altas na escala de prestígio, já que proporcionava (...) a oportunidade de ver diminuídas as invencíveis barreiras sociais (...)”33.

Com o final do nazismo a organização das viagens passam a serem feitas pela Federação dos Sindicatos Alemães e pelo Sindicato dos Operários Alemães. Foi desenvolvida a "viagem por poupança”, mas logo os sindicatos passaram a organização das viagens para organizações privadas que conseguiram rebaixar os custos das viagens. Por outro lado o esquema baseado na poupança não atingia de fato as camadas mais desfavorecidas, levando a se questionar se de fato havia um turismo social na Alemanha, uma vez que também era fruto de uma manipulação do nazismo.

Em 1936 a Organização Internacional do Trabalho (OIT) conquistou as férias remuneradas e os governos da Europa tornaram-se bastante atuantes socialmente. Durante os anos 50 muitas instituições de vocação social, sindicatos e cooperativas deram propulsão ao turismo social. Em 1945 a Declaração Universal dos Direitos do Homem prevê que “toda pessoa tem direito ao repouso e ao lazer e, notadamente, a uma limitação razoável de

\footnotetext{
${ }^{32}$ ALMEIDA, Marcelo Vilela. Turismo Social: Por uma compreensão mais adequada deste fenômeno e sua implicação prática na realidade brasileira.

33 Ibidem, p.54.
} 
duração do trabalho e a férias pagas, periodicamente” mais a frente contribuiu também a carta de Viena de 1972.

Na Europa os principais fatores que contribuíram para o desenvolvimento do turismo social foram: a conquista das férias remuneradas, a revolução tecnológica dos transportes e a redução de preços com as subvenções fornecidas pelo Estado ou grupos de empresas. Na França, a data legal de nascimento do turismo de massa "pode ser localizada em 1936, contribuíram para o nascimento do turismo popular a instituição dos doze dias de férias regulamentares, impostas a todas as empresas (força do Estado e sindicatos) e a redução da passagem de trem" (DUMAZEDIER, 2001, p.14) ${ }^{34}$.

No Brasil a década de 30 marca o início do desenvolvimento do Turismo Social. No governo de Getúlio Vargas a Lei de Férias foi aperfeiçoada em 1933. Os funcionários públicos do Estado de São Paulo construíam a sua primeira colônia de férias e nos anos 40 o SESC era criado por lei federal.

Várias práticas de Turismo Social acabaram sendo desenvolvidas no Brasil como, por exemplo, as viagens de um dia, os programas de governo como "O interior vai a praia" e as estadias em colônias de férias de trabalhadores de sindicatos e associações.

O fenômeno deu origem a debates a cerca do conceito, Baptistela (1982, p.23) ${ }^{35}$ destaca bem quando fala sobre o problema do amplo significado do termo social, que no caso se confunde com turismo de massas, popular, movimento sindical ou viagem de operários. Para Baptistela o conceito não pode ser exatamente sinônimo de:

- turismo de pobres economicamente falidos

- popular, reservado aos trabalhadores desfavorecidos, classes laboriosas famílias modestas.

\footnotetext{
${ }^{34}$ DUMAZEDIER, Joffre. Lazer e Cultura Popular. Série Debates, Ed. Perspectiva, São Paulo, 2001.

${ }^{35}$ BAPTISTELA, Humberto. Formulação de um programa de marketing de turismo social para o trabalhador. Tese de doutorado, FEA - USP, São Paulo, 1982.
} 
- de massa, em grandes grupos e condições péssimas de conforto

- público ou nacional voltado para regiões pobres

A essência do Turismo Social é o homem, portanto não poderia ser total e nem exclusivo de nenhum dos conceitos anteriores. Não é lucrativo e tem que se calcar na valorização da formação humana, afastando a imagem de penúria. Mas Baptistela ainda cita outros autores como Popliment e McIntosh ${ }^{36}$ que consideram o Turismo Social ser praticado por todos que não seriam capazes de custos sem intervenção social, isto é, sem a assistência de uma associação à qual o indivíduo pertença. Na França, organizações voltadas para esse fim, consideram um turismo "ao alcance de todos e que da àqueles que nem sempre tem os meios materiais e intelectuais a possibilidade de participar de uma viagem e de uma estada de férias, sob as melhores condições técnicas e culturais”37. Segue a definição de Baptistela para turismo social:

“Turismo Social é aquele que trata do deslocamento de pessoas de baixa renda sob a forma de viagem, passeios ou excursões para fora dos locais de residência, visando ao aproveitamento de tempo livre e utilizando os equipamentos normais do setor turístico, ou especialmente construídos para esse fim, mediante tarifas reduzidas, formas especiais de pagamento, instrumentos de subsídio, incentivos ou outras facilidades bem-definidas, estabelecidas ou concedida para entidades públicas e privadas visando ao bem estar social” ${ }^{38}$.

Questionemos por ora que tarifas reduzidas e formas especiais de pagamento não são privilégio apenas do turismo social e, além disso, não atingem apenas pessoas de baixa renda, mas também certos extratos de classes melhor remuneradas.

Voltando a Almeida há muita confusão terminológica a respeito de “turismo social”. É comum o uso indevido do termo inclusive com apelo mercadológico, cita como exemplo os passeios nas favelas do Rio de Janeiro. O objetivo da sua tese é de "possibilitar uma

\footnotetext{
${ }^{36}$ Ibdem, p.24

${ }^{37}$ Ibdem, p.25

${ }^{38}$ Ibdem, p.27
} 
reflexão sobre a real existência do turismo social na atual conjuntura socioeconômica brasileira, a partir de uma adequada compreensão de seu significado teórico e prático e, secundariamente, oferecer aos agentes operadores e ou promotores do turismo a aos administradores públicos um referencial para a elaboração de políticas e programas de gestão de turismo social...” e uma referência básica aos discentes sobre o tema ${ }^{39}$.

Almeida busca uma visão "diacrônica" sobre o turismo social, fruto de pesquisa bibliográfica. Alerta sobre a falta de compreensão adequada sobre o tema que leva a uma prática incipiente e indevida como as "estratégias de marketing" de empresas, sindicatos, associações,..., por outro lado, acredita que a promoção deva ser do Estado, do setor privado e organismos interessados bem como pela comunidade acadêmica. Certamente o autor tem razão quando fala sobre falta de compreensão sobre o tema, mas apenas conceituar com pesquisa bibliográfica o levou a muitos equívocos, como foi possível constatar, nem sempre subvenções e ou subsídios do Estado são imprescindíveis.

Na verdade, como pretendemos mostrar com as pesquisas, os subsídios ou subvenções públicas não são de fato preponderantes, apesar de ainda serem necessários, para que haja turismo social, algumas instituições como as associações podem promovê-lo apenas com seus próprios recursos. E, o conceito "trabalhadores de baixa renda" é algo que também merece melhor atenção, porque o verdadeiro trabalhador de baixa renda no Brasil está muito aquém de praticar um turismo social, sobretudo do tipo cuja estadia ocorra em uma colônia de férias.

No Brasil, o melhor exemplo de turismo social voltado para classes de baixa renda é aquele do tipo o interior vai à praia, cujo público-alvo são os alunos de escolas pública regularmente matriculados no ensino fundamental e médio e que via de regra apresentem bom desempenho escolar. Utiliza como forma de hospedagem escolas públicas e depende exclusivamente de recursos público-privados, seja no fornecimento de hospedagem, transporte e alimentação. Em geral é realizado na baixa-temporada sendo que a alimentação

\footnotetext{
${ }^{39}$ ALMEIDA, Marcelo Vilela. Turismo Social: Por uma compreensão mais adequada deste fenômeno e sua implicação prática na realidade brasileira, 2001, p.11.
} 
e acomodações adequadas para banho, higiene pessoal e local para dormir, fica totalmente por conta da unidade educacional receptora e o transporte pela instituição emissora. O tempo de permanência em geral é de uma semana e são oferecidas programações culturais como o resgate histórico do município visitado, reconhecimento de paisagens, visitas a museus e bibliotecas ${ }^{40}$.

Há algumas visões negativas sobre o projeto, mas acreditamos que o maior problema refere-se à adaptação das escolas públicas para recepcionar os alunos, ao invés de fazer uso das colônias de férias que são locais adequados para a recepção, até porque as mesmas apresentam grande vacância de leitos na baixa-temporada, vacância que é grande mesmo nos meses de janeiro e fevereiro excetuando as semanas com feriados. Voltaremos a tratar do assunto uma vez que se trata de grande demanda, somente em janeiro de 2006 foram contempladas 8860 crianças no Estado de São Paulo ${ }^{41}$.

Por conta das dificuldades em se desenvolver um turismo social realmente voltado para estratos sociais de baixa renda é que alguns autores fazem severas críticas à sua implementação. Na visão de Andrade (1998, p.84), esse tipo de turismo é uma forma especial de viagens, hospedagens, serviços e lazer, organizada para pessoas de camadas sociais cuja renda, sem a ajuda de terceiros, não lhes permitiria a programação, necessita de subsídios como recursos governamentais ou de fundos especiais. O autor faz uma dura crítica quando diz que em países com grandes problemas de qualidade de vida "qualquer esforço para a implantação de turismo social será a tradução do estado de estupidez e de deslavada demagogia de políticos irresponsáveis” ${ }^{\star 22}$.

É por conta de críticas como essas que se deve esclarecer que dentro das possibilidades de turismo social ocorrem situações que são totalmente financiadas por parcerias públicoprivadas, o que poderia de fato onerar o Estado fazendo com que este deixe de direcionar recursos para outras áreas estratégicas; o que não é o caso das colônias de férias de

\footnotetext{
${ }^{40}$ Dados das Secretarias de Educação dos Estados do Rio de Janeiro e de São Paulo, 2006.

${ }^{41}$ Dados da Secretaria da Educação e Secretaria de Economia e Planejamento do Estado de São Paulo, 2006.

${ }^{42}$ ANDRADE, José Vicente de. Turismo, fundamentos e dimensões.
} 
trabalhadores, pois, nesse caso, o próprio trabalhador tem de arcar com parcela dos custos e as instituições não recebem cem por cento de auxílio para manterem os empreendimentos, de forma que pensar em políticas públicas para o setor não necessariamente envolva “demagogia de políticos irresponsáveis”.

É da visão de Yázigi (2004, p.35) ${ }^{43}$. que entendemos que o conceito de turismo social sofre uma evolução bastante positiva, resumimos os princípios básicos:

- conjunto de medidas que tornam os custos mais vantajosos

- cidadãos que não podem custear as oferta de mercado e que estão filiados a alguma organização de classe.

- a iniciativa deve ser de órgãos aglutinadores de identidades profissionais, religiosas, desportistas, políticas, etárias e outras. A ação em grupo garante barganha na hora das negociações.

- o Estado normalmente aparece apenas como criador de estímulos fiscais.

- o turismo é uma forma de inclusão e da plenitude do homem

Outra visão bastante ampla é a do Bureau Internacional de Turismo Social (BITS) ${ }^{44}$, a instituição se define como uma ferramenta internacional para o desenvolvimento do turismo social no mundo. Foi criado em sete de junho de 1963, com sede em Bruxelas na Bélgica. É uma associação filantrópica internacional cuja finalidade é promover o turismo social. Sua filosofia de trabalho está baseada no artigo 24 da Declaração Universal dos Direitos Humanos, de 1948, que enfatiza o direito e a necessidade ao descanso, ao tempo de ócio, a um limite de horas de trabalho e às férias anuais remuneradas. Adicionalmente baseia-se também em duas convenções da Organização Internacional do Trabalho de 1936 e de 1970.

As principais áreas de atuação do BITS são a coordenação, colaboração e ajuda mútua

\footnotetext{
${ }^{43}$ YÁZIGI, Eduardo A. Por uma política de Turismo Social, 2004. Em anexo transcrevemos na íntegra os pontos mais relevantes levantados pelo referido autor em benefício do turismo social, a ser irradiado a partir do Estado Nacional dos quais voltaremos a tratar em momento oportuno.

${ }^{44}$ BITS. Bureau Internacional de Turismo Social. htpp://www.bits-int.org
} 
operacional em ações realizadas por seus membros na área de turismo, a concepção, estudo e pesquisa sobre turismo social e a divulgação de informações a respeito de turismo social.

Afirmou-se como uma fonte de intercâmbios de idéias e constituiu-se para os poderes públicos em um centro permanente de informações, capaz de instruir-lhes sobre a concepção e o desenvolvimento do turismo social no quadro de uma política nacional. Organizou várias reuniões técnicas e científicas, na forma de congressos, colóquios e seminários gerando uma variedade de documentos.

Os principais são a Carta de Viena (Carta do Turismo Social) de 1972, considerado o principal documento sobre o tema, servindo de guia para todas as entidades que busquem esta modalidade de turismo. Seus princípios fundamentais são: o turismo é parte integrante da vida social contemporânea e o acesso ao turismo deve ser um direito inalienável do indivíduo. Outro documento importante foi a Declaração de Montreal, conhecida por uma visão humanista e social do turismo, abordando questões de base comunitária, eqüidade social pelo turismo e no turismo, responsabilidades individuais de turistas e anfitriões, turismo para jovens, turismo para portadores de deficiências e economia social solidária.

O BITS é composto por mais de uma centena de membros e representa o setor de turismo social perante organismos internacionais como a Organização das Nações Unidas para Educação, Ciência e Cultura - UNESCO e a Organização Internacional do Trabalho -, além de ser membro da Organização mundial do Turismo e de atuar em parceria com a Associação Internacional de Turismo Social e com a Associação Internacional de Cooperativas de Turismo.

O que podemos afirmar, é que de fato não há uma definição precisa para o conceito de turismo social, na maioria das concepções encontramos as classificações de ser voltado para classes de baixa renda ou que não podem arcar com os custos "normais" de uma estadia. Infelizmente pode-se afirmar que é raro, ao menos do Brasil, o turismo social atingir efetivamente os de baixa renda e, pelo contrário, setores da classe média há muito já fazem o uso desse tipo de turismo, discutiremos isso melhor no capítulo sobre os custos de 
uma colônia de férias.

Deve-se destacar que tentativas de classificações para o turismo de uma forma geral são muito complexas. Beni (2004, p.424) vale-se da estratificação sócio-econômica dos turistas que comumente justapõem-se às semelhanças da pirâmide social, mas alerta que devido às diversas similaridades e complementaridades dos tipos de turismo exigi-se muitos debates para a necessária classificação e catalogação conceitual ${ }^{45}$.

A participação do Estado é outro ponto a ser discutido, ele ser "indispensável" certamente não é o ideal, se em sua concepção o turismo social esteve fortemente ligado ao Estado, não se pode negar que de alguma forma as forças sociais, notadamente as sindicais, exerceram pressão pelo direito ao lazer, ainda que no Brasil as relações entre Estado e sindicatos sempre foram muito fortemente ligadas. Ora, os sindicatos lutam pelos direitos dos trabalhadores, são conquistas e não favores. Isso também não quer dizer que governos não façam uso ideológico de manipulação. Como vimos Hitler o fez e como veremos o governo militar no Brasil também. Ocorre que políticas de governo podem acabar, mas as estruturas como as colônias persistem. Yázigi acerta quando diz aparecer o Estado normalmente como criador e incentivador de estímulos fiscais, mas depois, por exemplo, a gestão de uma colônia depende muito mais da associação ou sindicato do que qualquer ajuda do Estado ${ }^{46}$.

Um último problema, dizer que o turismo social oferece "equipamentos normais" de turismo não é verdadeiro em todas as situações, primeiro por que equipamentos normais não são algo fácil de ser definido, de qualquer forma como ainda discutiremos à frente, as viagens "O interior vai à praia” e algumas colônias não se enquadrariam no conceito “equipamentos normais”.

Utilizaremos em parte a conceituação sobre turismo social do BITS, por exemplo de se buscar algo mais amplo como uma visão humanista, cultural e social do turismo, de base

\footnotetext{
${ }^{45}$ BENI, Mário Carlos. Análise Estrutural do Turismo, 2004.

${ }^{46}$ YÁZIGI, Eduardo A. Por uma política de Turismo Social, 2004.
} 
comunitária e de uma economia solidária e envolvendo responsabilidades individuais de turistas e anfitriões. Procuraremos demonstrar no decorrer da pesquisa que pode-se aliar outras características ao conceito de turismo social como a adequação ao meio ambiente e ao planejamento urbano, inclusive no que concerne à proteção da paisagem e à identidade do lugar, como uma necessidade ao turismo.

\subsection{As colônias de férias}

O primeiro ponto a ser esclarecido é de qual tipo de colônia de férias está sendo tratado. Em absoluto não estará sendo discutido sobre albergues da juventude (apesar de na origem estarem ligados aos movimentos trabalhistas) e nem de colônias de recreação para crianças.

O tipo de hospedagem que aqui é tratado tem como características principais oferecer estadias de médio a bons padrões de acomodamento, em geral com refeições inclusas além de uma série de equipamentos que vão de piscinas, quadras poliesportivas, bibliotecas ou cybercafés. O número de hóspedes por quarto varia de três até seis pessoas. O custo é sempre inferior ao de uma pousada. Efetivamente, todas as colônias que aqui foram pesquisadas estão ligadas a uma associação de classe ou sindicato, de certa forma que invariavelmente são também um centro estratégico de desenvolvimento cultural.

A história das colônias de férias está totalmente ligada ao desenvolvimento industrial e às lutas trabalhistas em busca de melhores condições de vida. Sobretudo a partir da década de 30 surgiam na Europa, lideranças sindicais lutando por melhores salários e condições de trabalho, mas também para atender a outras necessidades do trabalhador.

De acordo com Dumazedier na França dos anos 20 são criados os primeiros clubes trabalhistas e cita que "os albergues de la Jeusesse são criados em 1930 com sucesso”, referiam-se então os operários ao lazer como alegria de viver e o sentido de sua dignidade $\left(2001\right.$, p.58) ${ }^{47}$. O direito as férias passam a serem tratados como uma necessidade do trabalhador e para a sua família. As colônias surgem como a possibilidade de cooperação

\footnotetext{
${ }^{47}$ DUMAZEDIER, Joffre. Lazer e Cultura Popular.
} 
na obtenção de redução de custos, podendo ser considerado o uso delas dentro da modalidade de turismo social.

No Brasil, a primeira lei de incentivo ao lazer do trabalhador, foi criada pelo então presidente Getúlio Vargas em $1^{\circ}$ de maio de 1943, que aprovou a Consolidação das Leis do Trabalho (CLT) através do decreto lei nº5452.

A CLT, ao tratar Da Contribuição Sindical, determina que a mesma deve ser recolhida pelos sindicatos anualmente, no valor de um dia de trabalho, bem como regulamenta o uso que os sindicatos podem fazer desta. Entre os onze itens definidos pelo Art. 592 do texto da CLT, que trata Da Aplicação da Contribuição Sindical, destaca-se alíneas referentes ao campo do lazer, passando, portanto, os sindicatos a terem obrigatoriedade na sua organização, a saber: "g) em colônias de férias; (...) i) em finalidades esportivas e sociais.

Dos levantamentos feitos pela pesquisa, a primeira colônia de férias no Brasil data do ano de 1934, no município do Guarujá, no litoral do Estado de São Paulo, na baixada santista, inaugurado pelos funcionários públicos desse mesmo estado. No ano de 1948 é inaugurada a primeira colônia do sistema SESC no município de Bertioga, também no litoral paulista.

No entanto, a grande explosão do surgimento de colônias no Estado de São Paulo se dá entre os anos 60 e 70 quando muitos sindicatos de trabalhadores receberam doações de terrenos feitas pelo governo militar notadamente nos município litorâneos de Praia Grande e Caraguatatuba ${ }^{48}$. Foi a maior intervenção de uma política de governo voltada ao turismo social, sem, no entanto haver preocupações de monta maior no que se refere aos impactos ambientais que tal proposição poderia desencadear.

De acordo com o Ministério do Turismo em um universo de dez categorias por tipo de hospedagem a modalidade em colônia de férias ocupa a sétima e última posição

\footnotetext{
${ }^{48}$ Ver GONÇALVES Júnior, Luiz (in: Lazer no período da ditadura militar: o desvelar de depoimentos de sindicalistas da Grande São Paulo, 2002).
} 
respectivamente em viagens domésticas e rotineiras. É na região sudeste que está a maior concentração deste tipo de hospedagem, sendo que dentro da região corresponde a 2,3\% por tipo de hospedagem em viagens domésticas. Certamente uma porcentagem pequena em vista do potencial de uso que as colônias oferecem ${ }^{49}$.

No capítulo a seguir analisamos com detalhes três instituições que atuam no Estado de São Paulo oferecendo o serviço de colônia de férias de trabalhadores. Apesar de todas visarem o mesmo objetivo: do lazer do trabalhador e de sua família através do turismo, observaremos importantes diferenças, sobretudo na forma de gestão e na qualidade dos serviços oferecidos.

\footnotetext{
${ }^{49}$ Fonte: Ministério do Turismo, 2001. A categoria colônia de férias pouco aparece nos censos praticados pelo
} MT, o que certamente merece uma maior atenção no refinamento dos dados. 


\section{CAPÍTULO 3: AS INSTITUIÇÕES ANALISADAS}

Destacamos duas formas principais de organização de colônias de férias: as de sindicatos de trabalhadores e as do tipo de associações. Com relação ao sindicato de trabalhadores foram estudadas principalmente as colônias do Sindicato dos Trabalhadores da Indústria de Brinquedos e Aparelhos Musicais e da Federação dos Químicos e Farmacêuticos (FEQUIMFAR), ambos na Praia Grande. Do segundo tipo trataremos do sistema de colônias da Associação dos Funcionários Públicos do Estado de São Paulo (AFPESP). Ainda deve-se destacar o Serviço Social do Comércio (SESC - Bertioga) que representa ao mesmo tempo um paradigma a ser seguido, mas que por outro lado só consegue ser o exemplo que é por ser uma das mais subsidiadas organizações.

O mapa (anexo 4 p.111) a seguir foi um esforço de se fazer um levantamento da distribuição das colônias de férias no Estado de São Paulo, portanto ele não indica todos os municípios que possuem essa forma de hospedagem, mas demonstra claramente a concentração no litoral, aparecendo em segundo lugar a opção montanha e em poucas situações a opção rio.

Iniciaremos a análise pelo SESC, seguido pela AFPESP e por último das colônias ligadas ao sindicato dos químicos que representa a base mais empírica da pesquisa 
compondo um estudo de caso.

\subsection{O Serviço Social do Comércio (SESC)}

A Entidade foi criada através do Decreto-Lei nº.853 em 13 de setembro de 1946 durante o governo do Presidente Eurico Gaspar Dutra. Numa iniciativa liderada por empresários e organizações sindicais do comércio com finalidade inicialmente voltada para a assistência social no sentido de buscar uma sociedade mais justa subsidiando serviços ao trabalhador do comércio de bens e serviços que prioritariamente fosse de baixa renda.

Segundo seu conselho nacional, desde 1948 o SESC (Serviço Social do Comércio) trabalha com o turismo social de acordo com os conceitos do Boreau International du Tourisme Social (BITS) que define o turismo social como o conjunto de relações e fenômenos resultantes da participação no turismo de camadas sociais menos favorecidas, participação que se torna possível ou facilitada por meios de caráter social bem definido, mas que implicam um predomínio da idéia de serviço e não de lucro.

De acordo com a ideologia do SESC o turismo pode ser uma forma de inclusão social, democratizando o acesso ao "produto turístico", criando relações entre cultura, educação, meio ambiente, lazer e saúde do intercâmbio de conhecimento e das chances de desenvolver relações interpessoais, além do desenvolvimento econômico gerando empregos diretos e indiretos nas áreas de serviços de transporte, alimentação, hospedagem e entretenimento. Seus objetivos passam pela idéia de democratizar o acesso a viagens pelo território nacional, com preços acessíveis e uma rede hoteleira própria possibilitando o aceso de pessoas de baixa renda.

A entidade busca difundir bens e patrimônios socioculturais contemporâneos, como meio de despertar a consciência histórica, ecológica e comunitária dos viajantes, dos anfitriões e das empresas que estão envolvidas com a instituição. Na visão de seus idealizadores democratizar um lugar turístico "é criarmos cumplicidade com ele, entendendo-o como espaço público, habitado e fruído por uma ampla e espessa rede de 
atores sociais e fatores ambientais em permanente tensão, em busca de equilíbrio. Assim, o exercício democrático do turismo envolve escolhas responsáveis da instituição e um permanente exercício de formação do público para a co-responsabilidade da experiência por isso, o conceito de turismo do SESC SP é político e educativo”50

O SESC acredita ser o turismo social capaz de se tornar "um símbolo genuíno de uma coesão social de sucesso no mundo e representar o espaço onde o homem com seu poder de comunicação e conhecimento educacional, cultural e ambiental será capaz de enriquecer as trocas com pessoas, tradições e culturas” transformando-se em um turismo do desenvolvimento. ${ }^{51}$

O grupo apresenta um alto grau de organização articulando diversos projetos em todo o país (nos 26 estados e Distrito Federal), atuando nas áreas de educação, saúde, cultura, lazer e assistência social, quem já entrou em alguma unidade do SESC reconhece a qualidade e eficácia em todos os serviços oferecidos. O conceito de ação social do grupo é pautado no caráter educativo, pretende "um desenvolvimento integral dos indivíduos, mediante a melhoria de suas condições de existência, elevando seu grau de percepção de si mesmos, sua elevação sociocultural e desenvolvimento de valores próprios de uma sociedade em mudança e que o façam sujeito ativo deste processo de transformação social em busca de um mundo melhor para todos” ${ }^{2}$.

Todo o padrão de qualidade da entidade tem fundamentos claros, com receitas garantidas e um grupo de quase 15 mil técnicos especializados nas diversas áreas da cultura e educação, do “puro” lazer e dos esportes. O trabalho de divulgação/informação também é muito bom, seu guia é excelente referência ao turista contando com importantes informações de atrações, hospedagem e serviços em geral.

Com relação à colônia em Bertioga, a colônia apresenta características bastante peculiares, teve seu traçado urbanístico encomendado ao engenheiro e urbanista Francisco

\footnotetext{
50 Turismo social no SESC- SP, p.4, 2006.

51 Turismo social no SESC- SP, p.6, 2006.

52 SESC - Trajetória de sucesso, p.6, 2004.
} 
Prestes Maia prevendo abrigar cerca de 60 mil pessoas por ano. Atualmente pode hospedar simultaneamente até 1 mil pessoas por dia, conta com 50 casas para grupos de 8 a 12 pessoas e 11 conjuntos de apartamentos para 2 a 5 pessoas.

A área total é de 1.034.799 metros quadrados, que ocupam da praia até o sopé da Serra do Mar, na qual 3,8\% correspondem à área construída, com instalações de hospedagem, recreação, manutenção, alimentação e administração. Os equipamentos de lazer e recreação são compostos pelo ginásio de esportes, canchas de bocha e malha, quadras de tênis e poliesportivas, pistas de cooper, campos de futebol, mini-campos de grama sintética e natural, sala de leitura, parque aquático, brinquedo aquático, sala de jogos, sala de vídeo, cinema, sala de ginástica, viveiro de plantas, “espaço do corpo”, restaurante, café e lanchonete e loja SESC.

O restante da área é coberto por vegetação nativa com mata de restinga, manguezal e mata atlântica, várias espécies de árvores ornamentais e frutíferas compõem o jardim. Há um abastecimento de água potável com sistema próprio de captação, tratamento e distribuição, com capacidade de 960 metros cúbicos por dia. Também conta com sistema de tratamento de esgoto próprio com capacidade de atendimento de até 2 mil pessoas, situadô fora da área de hospedagem e recreação. Em 1993 foi criado o projeto avifauna de preservação das cerca de 113 espécies existentes dentro do terreno. Conjuntamente há o manejo da vegetação existente.

A questão ambiental ganhou bastante força nos projetos de viagens do SESC nas últimas décadas promovendo programas de turismo voltados para a conservação do meio ambiente "inclusive, observando iniciativas de reabilitação e técnicas de gestão ambiental”. É claramente intencional a idéia de educação ambiental, envolvendo iniciativas de preservação, limpeza e manutenção nas regiões visitadas como atividades de lazer entre os turistas (considerado ecoturismo) e passeios e trilhas (turismo ecológico). Certamente os projetos de maior interessante para o meio ambiente são os da Reserva Particular do Patrimônio Natural (RPPN) no SESC Pantanal, um complexo de turismo ecológico e de lazer envolvendo um hotel em Porto Cercado e do Parque SESC Baía das Pedras, na 
margem direita do rio Cuiabá. Outro projeto ainda em fase de conclusão ocorre em Roraima, Amajari, a estância ecológica de Tepequém.

É de interesse explicar que a idéia das RPPNs representam uma das formas mais avançadas de uso do território do ponto de vista do meio ambiente e do desenvolvimento sustentável, inclusive para o turismo. Seus marcos conceituais e referenciais são baseados no Sistema Nacional de Unidades de Conservação (SNUC). Conforme estabelecem a Lei e o Regulamento do SNUC, cabe ao IBAMA o mandato legal de elaborar e disponibilizar roteiros metodológicos para a elaboração de planos de manejo para as diferentes categorias de unidades de conservação (UC) federais, criando as principais referências para a orientação e uniformização das questões que regem o manejo e a gestão das unidades ${ }^{53}$.

No campo do lazer e especificamente no turismo social, o SESC defende uma filosofia de atuação cultural propondo uma integração com todo o equipamento de lazer na busca de levar o indivíduo às suas potencialidades de desenvolvimento. Conceitualmente defendem a emancipação de grupos de turistas cujo poder aquisitivo não lhes permitiria, em condições normais, o acesso ao produto turístico. Não resta dúvidas sobre a importância social que a instituição desenvolve no campo do turismo, são hotéis (alguns associados e outros próprios), pousadas, colônias e unidades por todo o território nacional, são instalações em geral de ótimo padrão tudo isso por preços relativamente acessíveis, mas não de fato para o trabalhador de baixa renda.

Como paradigma a ser seguido não se pode perder de vista que a entidade ao ser criada passou a contar com importante fonte de renda arrecadada via governo federal, além de outras receitas tradicionais como de outras instituições, ao exemplo das taxas mínimas para uso e manutenção de seus diversos equipamentos. É também bastante relevante destacar que, atualmente, para se utilizar o SESC não é preciso ser comerciário, que no caso seria o associado. Pagando-se taxas maiores, qualquer cidadão pode se tornar um "usuário” ou cliente, como assim o grupo convencionou.

53 IBGE - Roteiro Metodológico para Elaboração de Plano de Manejo para Reservas Particulares do Patrimônio Natural. Brasília, 2004. 
O debate mais atual vem sendo travado com respeito ao destino da arrecadação: por força da lei o sindicato patronal é responsável boa parte do financiamento não apenas do SESC e também de todo o sistema $\mathrm{S}^{54}$, uma parcela deste sindicato quer se livrar da imposição do imposto, o que resultaria sem dúvida em tremenda perda de recursos colocando em risco a qualidade dos serviços oferecidos pelo grupo, outra possibilidade sobre o futuro da arrecadação parte do Ministério da Educação que pretende inverter a proporcionalidade das cotas, pois o SESC fica com 60\% de todo o recurso, a intenção é destinar estes 60\% para as entidades voltadas para a formação de profissionais qualificados, inclusive com isenção de custos para alunos da rede pública de ensino.

Então como exemplo, e não modelo ideal, a ser seguido não resta dúvidas ser uma entidade que contribua para o desenvolvimento social, fica aqui como discussão a possibilidade de outras organizações voltadas para o turismo social desenvolverem projetos tão bons quanto os do SESC e quem sabe obterem receitas também igualmente boas.

De qualquer forma, devemos aprender com o SESC, se de fato ele atende ou deixa de atender as classes de baixa renda é algo importante de se comprovar, pois o que no momento fica mais evidente é de que apenas esta instituição pouco pode cobrir das necessidades de lazer e turismo da população como um todo. Outras instituições poderiam talvez adotar alguns dos métodos do SESC, e quem sabe até melhorá-los.

\subsection{A Associação dos Funcionários Públicos do Estado de São Paulo (AFPESP)}

A associação foi fundada em 05 de novembro de 1931 como sociedade civil sem fins lucrativos. É considerada a maior entidade do gênero em toda a América Latina, com mais de 210 mil associados e um patrimônio sólido em crescimento, principalmente baseado em suas colônias de férias, designadas Unidades Recreativas e de Lazer (URLs,

\footnotetext{
${ }^{54}$ O sistema "S", que envolve além do SESC diversas outras entidades como o Instituto Nacional de Colonização e Reforma Agrária (INCRA), Serviço Nacional de Aprendizagem Industrial (SENAI), Serviço Nacional de Aprendizagem do Comércio (SENAC).
} 
são ao todo 11 unidades), delegacias e escritórios em vários municípios do Estado de São Paulo ${ }^{55}$.

No Brasil a entidade é pioneira no fomento de colônias de férias de trabalhadores, data de 1933 a aquisição de uma escola de pesca formada principalmente por espanhóis no bairro das Astúrias no Guarujá. As instalações são inauguradas em 1934 para comportar 60 associados a cada 15 dias dos então 9 mil associados. Em 1949 a estância balneária obteve cancelados todos os impostos e taxas devidas até aquela data e ficou isenta de pagamentos futuros, com exceção da energia elétrica. Após diversas reformas e ampliações é entregue em 1991 um edifício de 17 andares de surpreendente infra-estrutura, destacamos a presença de um ambulatório, anfiteatro, salão de beleza, biblioteca, espaço cyber, restaurante, lanchonetes, berçário, copa e rouparia em diversos andares. Na cobertura encontram-se 104 placas de captação de energia solar. Todo esse empreendimento realizado e projetado tendo como única fonte de renda as contribuições sociais (pág. 107 a 113, 1998) ${ }^{56}$.

A segunda colônia foi idealizada a partir de 1952 em Campos do Jordão com a aquisição paulatina de terrenos, somando mais de 46.000 mil metros quadrados a partir de recursos da própria associação, excetuando uma parcela de um mil metros quadrados fruto de doação. Em 1969 é inaugurada a colônia de Poços de Caldas no Estado de Minas Gerais que conta com isenção do Imposto Sobre Serviço desde 1981. No município de Amparo, a entidade adquiriu em 1972 o Hotel das Fontes da Bocaina através de uma concessão de direito real de uso, instalando ali uma colônia com 40 apartamentos. Em 1975, a associação obteve um terreno em Caraguatatuba através de uma doação em regime de comodato, que posteriormente foi alienado em 1978 como doação definitiva, sendo inaugurada sua quarta colônia no ano de 1985. Com recursos próprios é adquirido em 1977 o Camping Estância de Lindóia, no mesmo ano a Prefeitura de Areado, em Minas Gerais, doa um terreno de pouco mais de 6 mil metros quadrados, onde a associação só consegue concluir uma colônia em 2006. No município de Socorro, em 1982, foi inaugurada nova colônia em um terreno de mais de 52.000 metros quadrados do Governo do Estado, com permissão de uso

\footnotetext{
${ }^{55}$ Durand e Moreira, in: A história da AFPESP em 66 anos, 1998.

${ }^{56}$ Ibdem.
} 
e posse definitiva através de concorrência pública em 1997, a associação ainda comprou um terreno com mais de 260.000 mil metros quadrados onde se localizam fontes de água mineral. Em Serra Negra, no ano de 1996, é comprada uma área de 27 mil alqueires onde foi levantado também em 2006 um Hotel Fazenda (pág.114 a 127, 1998) ${ }^{57}$. Em dezembro de 2006 é inaugurada mais uma Unidade Recreativa e de Lazer desta vez no município de Ubatuba, construção realizada com base no resultado de pesquisa de opinião, feita no início de 2001, quando 85\% dos associados pediram uma opção de lazer no litoral norte. Ainda no ano de 2006 a associação inaugura outra colônia, no município de Avaré, em terreno com área de 40 mil metros quadrados. ${ }^{58}$

Sobre a gestão da entidade vale a pena ainda analisarmos os dados a seguir: possui certificação do ISO 9000, com mais de 225 mil associados, um ativo permanente de 143.820.493,65 reais, com ativo real líquido de 212. 132.893,60 reais (cerca de dez mil reais de superávit financeiro) ${ }^{59}$.

De acordo com o discurso da entidade, revela que "os segredos dessa estabilidade e crescimento” estão ligados à “confiança que o funcionalismo público paulista deposita na Associação”, mas também na dedicação dos diretores executivos, conselheiros e coordenadores, “que tem se revezado à frente da entidade”, de participação voluntária e “sem nenhum tipo de remuneração”, da administração da AFPESP. De acordo com a Folha do Servidor "pode até parecer contraditório, mas a AFPESP consegue conciliar um espírito familiar com os mais modernos métodos de gerenciamento”. 60

O diretor econômico-financeiro explica que mesmo com a boa procura das URLs e com as "medidas gerenciais de controle absoluto das despesas", há ainda a necessidade de repasses para o bom funcionamento das colônias. Por isso, “em todas as diárias das Unidades há uma parcela de despesas cobertas pela Associação. Isto significa que para

\footnotetext{
${ }^{57}$ Ibdem

${ }^{58}$ Folha do Servidor Público, n ${ }^{\circ}$ 161, abril de 2006.

${ }^{59}$ Folha do Servidor Público, no 171, fevereiro de 2007.

${ }^{60}$ Folha do Servidor Público, n 170, janeiro de 2007.
} 
manter o valor atual das diárias, compatível com a realidade financeira do servidor público, a AFPESP subsidia gastos operacionais. Cada URL tem um percentual de despesas não cobertas pelas receitas; podemos estimar que aproximadamente são subsidiados $20 \%$ das despesas gerais” ${ }^{\prime 61}$.

A idéia de gerenciamento da entidade, ao menos nos últimos anos, foi o de sempre estar melhorando a infra-estrutura, sempre buscando inovar seus atrativos de lazer, com colônias em regiões de paisagens diversas, seja no litoral do Guarujá e Ubatuba, na montanha em Campos do Jordão e Serra Negra ou com esportes náuticos como é em Areado.

Como associação, a entidade ainda oferece diversos serviços ao associado como um belo clube às margens da Represa do Guarapiranga na cidade de São Paulo, seguros, passeios turísticos e outros. Como movimento social ligado ao trabalho procura participar de importantes debates como os projetos para previdência, recursos para o hospital do servidor estadual e campanhas salariais. Como modelo de gestão, ao menos no que se refere às colônias de férias, parece-nos ser a forma da associação um modelo bastante adaptado às novas necessidades contemporâneas, que exigem uma visão sócio-econômica e ambiental ligada ao turismo, oferecendo um bom padrão de hotelaria e praticando uma forma de apropriação do espaço almejando critérios necessários à prática do planejamento e invejável preocupação com a paisagem.

\subsection{Federação dos Químicos e Farmacêuticos do Estado de São Paulo (FEQUIMFAR)}

Organização sindical fundada em 1958, conta atualmente com 33 sindicatos representando cerca de 100 mil trabalhadores no Estado de São Paulo e está ligada à Força Sindical. Dentre os 23 segmentos de atividade do setor químico que compõe a federação destacam-se setores como o farmacêutico e o sucroalcooleiro ${ }^{62}$.

\footnotetext{
${ }^{61}$ Ibdem

${ }^{62}$ São os Sindicatos dos Trabalhadores da Indústria Química de: Americana, Araçatuba, Araras, Bauru, Botucatu, Cosmópolis, Guairá, Guaratinguetá, Guarulhos, Ipaussú,Itapecerica da Serra, Itatiba, Jaguariúna, Jundiaí, Lorena, Marília, Pindamonhangaba, Presidente Prudente, Ribeirão Preto, Rio Claro, Salto, Santa
} 
São ao todo cinco colônias ligadas à Federação, que possui sua própria colônia no município de Praia Grande, construída na década de 70, na Avenida dos Sindicatos em terreno doado pelo governo, com capacidade para atender até 350 hóspedes. Após grande reforma sua atual infra-estrutura passou a contar com um novo bar e um moderno refeitório além de auditório com capacidade para 60 pessoas, palco para pequenos shows, videokê e área de lazer e jogos. Outra colônia é a do STI Brinquedos, a mais antiga das colônias dos Sindicatos associados a FEQUIMFAR. Também localizada em Praia Grande foi fundada no ano de 1949, com aquisição do terreno. Após reformas passou contar com 31 apartamentos que acomodam 150 hóspedes. A Colônia possui duas piscinas, área para banho de sol, quadra esportiva, sala de TV, salão de jogos, estacionamento e refeitório. Ainda em Praia Grande o STI de Rio Claro inaugurou sua colônia em 2005 para cerca de 70 hóspedes no Bairro da Vila Guilhermina. Em Bertioga está a colônia do STI de Suzano, para 96 hóspedes. E em Caraguatatuba a colônia do STI Guarulhos, fundada em 28 de junho de 1992, com capacidade para 72 hospedes, distribuídos nos seus 12 apartamentos, equipados com televisores, cozinha anexa, ventiladores, geladeiras e utensílios domésticos para cozinhar. Também possui estacionamento e salão de jogos. Ainda há os clubes de campo nos municípios de Jundiaí, Sorocaba e Miriporã, um centro de Lazer em Salto e uma Atlética em Jundiaí ${ }^{63}$.

São colônias que não oferecem atrativos diferenciados (bibliotecas, cyber cafés, termas, esportes náuticos, reservas naturais) ao exemplo das outras entidades já descritas. Os refeitórios oferecem alimentação a preços populares e as acomodações são em geral pequenas para a média de seis hóspedes por quarto. A forma de gestão das colônias não é integrada sendo que cada sindicato adota diferentes posturas administrativas, algumas extremamente centralizadas no próprio sindicato, outras de forma terceirizada.

A respeito da entidade frente aos movimentos sindicais podemos dizer que muito do que já se escreve sobre as novas adaptações do sindicalismo frente às transformações

Rosa do Viterbo,Santos, São Carlos, São João da Boa Vista, São José do Rio Preto, Sorocaba, Suzano, Tatuí, Vale do Ribeira, Plásticos de Jundiaí, Abrasivos de São Paulo e Brinquedos e Instrumentos Musicais.

${ }^{63}$ Fonte: www.fequimfar.org.br 
contemporâneas impostas pelo neoliberalismo - maior integração sindical, associação a movimentos sociais, internacionalização, conquista de benefícios - pode ser notado em parte nos discursos e nas ações notificadas nos periódicos da FEQUIMFAR.

São discutidos diversos temas como as negociações, conquistas e outras preocupações sociais e ambientais. São temas como convenções reivindicando fornecimento gratuito de medicamentos, assistência médica, vale-compras, cursos profissionalizantes, redução da jornada e o respeito aos direitos das mulheres, sobre os benefícios da luta pelo contrato coletivo nacional, envolvimento em conferências internacionais. As questões ambientais são de grande relevância, não apenas no chão de fábrica onde em certos lugares ainda há os riscos de trabalho pelo uso de produtos como o benzeno, mas também por questões econômicas e ambientais fundamentalmente no que se refere ao uso do álcool combustível, um setor em franca expansão tanto no mercado interno como para exportação.

É possível notar a renovação do sindicato a partir do discurso: "Muitas entidades sindicais mantêm parcerias e convênios com escolas e universidades, algumas realizam e promovem diversos cursos e treinamentos profissionalizantes. Isso tudo, além da produção de programas de televisão com dicas e informações sobre o dia-a-dia sindical. Existem também parcerias com iniciativas privadas, na área da saúde, onde são oferecidos planos, descontos em exames e medicamentos. Na área financeira, existem os convênios com bancos e instituições, para realização de empréstimos. Isso tudo e muito mais: turismo, lazer, esporte, são algumas áreas em que as entidades sindicais atuam”64.

É defendida a idéia de um “sindicato cidadão”, que se preocupa com os trabalhadores de todo o país, com os aposentados e com os desempregados. Mas há também um reconhecimento das dificuldades para o sindicalismo contemporâneo, há um entendimento sobre a dificuldade de realização do movimento como luta verdadeira e sobre a perda de força da reforma estrutural sindical corporativista.

\footnotetext{
${ }^{64}$ Jornal da Federação nº 82, pág.8, 2005.
} 
Cito alguns exemplos de outras formas de atuação da entidade como destaque o projeto “Verão sem AIDS”, que pude vivenciar. Foi implementado pelo departamento de Saúde da FEQUIMFAR a partir de 1996 em sua colônia de férias na Praia Grande, com o intuito de despertar o interesse do trabalhador e de seus familiares sobre os problemas trazidos pela doença, conscientizando-o e prevenindo-o, trabalho que inicialmente sofreu resistências por se tratar ainda de assunto tabu na sociedade naquele momento.

Toda a campanha envolve palestras no auditório da colônia, distribuição gratuita e demonstração de uso de preservativos, montagem de painéis explicativos, atividades culturais e distribuição de material informativo nas praias. Para o funcionamento da campanha são criadas equipes de trabalho com envolvimento de dirigentes sindicais com importante apoio do município através da secretaria da saúde. Também muitas empresas se envolvem com recursos financeiros e materiais de divulgação como a Kodak, Resana S/A, Faber Castell, Cardinali, Sonoco For-Plas e a DKT preservativos do Brasil.

O sucesso do projeto proporcionou um convênio com o Ministério da Saúde e a UNDCP - Programa das Nações Unidas para o Controle Internacional de Drogas, incluindo os temas DST e drogas, no entanto os recursos do governo federal foram cortados a partir da nova conjuntura política que se estabeleceu a partir de 2002. De qualquer forma o projeto continuou a ser mantido pela Federação e de seus sindicatos filiados juntamente com outras parcerias público-privadas.

A idéia do projeto foi baseada na justificativa de ser a colônia de férias o local de grande atração do trabalhador e de seus familiares e de ser justamente no verão a época em que aumentam os casos de AIDS. O envolvimento dos trabalhadores e de seus familiares é real e bastante positivo, participam ativamente das palestras e atividades culturais além de se envolverem na distribuição de materiais informativos.

Em muitas colônias de sindicatos é comum presenciar seu uso para marcar grandes congressos ou mesmo pequenos encontros com jovens lideranças sindicais, fortalecendo laços e entendimentos. 
Como fruto da pesquisa e em decorrência de uma maior aproximação com os líderes da FEQUIMFAR, foi realizado um levantamento sobre os custos e conseqüentemente uma discussão a cerca da forma de gestão das colônias explanada no próximo capítulo. O exercício dessa reflexão levou-nos à comparação entre os modelos de gestão das entidades acima discutidas, exigindo um aprofundamento sobre as formas de movimentos sociais, notadamente sobre as associações e os sindicatos. 


\section{CAPÍTULO 4 : RELAÇÕES DE CUSTO E BENEFÍCIO}

A análise sobre custo e benefício, feita a partir dos dados obtidos, teve como base a comparação entre as planilhas do valor das diárias, assim cobrados pelas instituições analisadas bem como pelos respectivos serviços oferecidos. Também foi possível avaliar de forma mais empírica algumas vivências que obtivemos através de trabalho de campo envolvendo colônias de férias de sindicatos no município de Praia Grande.

Sobre as relações que procuramos desenvolver buscou-se demonstrar que valores maiores de diárias resultam, via de regra, em melhores condições de estadia. Lugares com um apelo turístico diferenciado costumam encarecer as diárias, por outro lado, de acordo com a sazonalidade, como na baixa temporada há um barateamento das diárias. As formas de subsídios também são levadas em conta, embora somos inclinados a acreditar que não seja o elemento preponderante para os custos, ao menos em certas situações. De qualquer forma, já afirmamos, o Estado foi e continuará a ser o fomentador das políticas para o desenvolvimento das várias formas de turismo social, ainda sendo indispensável. O elemento central, portanto, refere-se às formas de gestão que cada instituição desenvolve na administração das colônias, o que nos remeteu a uma discussão mais acentuada sobre o 
papel dos sindicatos e das associações como empreendedores e gestores do lazer para o trabalhador.

A tabela a seguir compara o valor das diárias cobradas entre algumas colônias do SESC, AFPESP e colônias de sindicatos ligados a FEQUIMFAR no ano de 2006, a consulta das fontes foi então feita nos próprios escritórios responsáveis pelo departamento de turismo.

\section{TABELA 1}

Valores de algumas diárias em colônias de férias, diárias com todas as refeições incluídas em reais.

\begin{tabular}{|l|c|c|}
\hline \multicolumn{2}{|c|}{ adultos } & Até 7 anos não pagam \\
\hline \multicolumn{1}{|c|}{$\begin{array}{c}\text { Sindicato dos Brinquedos - Praia } \\
\text { Grande }\end{array}$} & 25,00 & Até 7 anos não pagam \\
\hline $\begin{array}{l}\text { Sindicato dos Químicos - Praia } \\
\text { Grande }\end{array}$ & 25,00 & Até 7 anos não pagam \\
\hline AFPESP - Guarujá & 45,00 & Até 7 anos não pagam \\
\hline AFPESP - Campos do Jordão & 45,00 & Até 7 anos não pagam \\
\hline AFPESP - Poços de Caldas & 45,00 & Até 7 anos não pagam \\
\hline AFPESP - Lindóia & 34,00 & Até 7 anos não pagam \\
\hline AFPESP - Caraguatatuba & 27,00 & 25,00 até 11 anos \\
\hline SESC - Bertioga & 50,00 & 34,00 até 11 anos \\
\hline SESC - Teresópolis RJ & 50,00 & 90,00 até 11 anos \\
\hline SESC - Porto Cercado MT & 116,00 & 120,00 até 11 anos \\
\hline SESC - Tapéquem RR & 190,00 & 20,00 entre 5 e 8 anos \\
\hline APEOESP - Ibirá & 40,00 & 18,00 entre 5 e 8 anos \\
\hline APEOESP- Ubatuba & 31,00 & \\
\hline
\end{tabular}

Como podemos observar as colônias do Serviço Social do Comércio são as que apresentam os maiores valores de diárias, seguidas pelas colônias da Associação dos Funcionários Públicos sendo as de menor valor as colônias de sindicatos de trabalhadores.

Relembrando algumas características a respeito dos serviços oferecidos pelas referidas 
instituições, a AFPESP e o SESC oferecem o que podemos considerar de um elevado padrão de hotelaria para a categoria das colônias de férias. Em média acomodam em suas dependências três a quatro hospedes por quarto, oferecem serviços diferenciados como bibliotecas, cyber cafés, esportes náuticos. A oferta de diferentes ambientes turísticos é bastante diversificada variando do litoral, do campo, e da montanha.

As diárias mais caras do SESC em Porto Cercado (MT) e Tapéquem (RR) justificam-se por serem empreendimentos em área de Reserva Particular de Patrimônio Nacional. A idéia das RPPNs representam uma das formas mais avançadas de uso do território ambientalmente e sustentávelmente falando, inclusive para o turismo. Seus marcos conceituais e referenciais são baseados no Sistema Nacional de Unidades de Conservação (SNUC). Conforme estabelecem a Lei e o Regulamento do SNUC, cabe ao IBAMA o mandato legal de elaborar e disponibilizar roteiros metodológicos para a elaboração de planos de manejo para as diferentes categorias de unidades de conservação federais(UC), criando as principais referências para a orientação e uniformização das questões que regem o manejo e a gestão das unidades.

No momento em que o IBAMA disponibiliza este instrumento está cumprindo com sua missão como órgão executor das políticas públicas relativas ao meio ambiente e, ao mesmo tempo, reconhecendo o importante papel da participação da sociedade e notadamente daqueles proprietários que, ao gravarem com títulos de perpetuidade as áreas estabelecidas como RPPN, juntam-se ao poder público na proteção da biodiversidade brasileira. É uma ação do Estado que busca de forma planejada através de forte regulamentação possibilitar uma ocupação racional do espaço.

O roteiro de manejo das RPPNs foi proposto obedecendo, ao disposto no Decreto $\mathrm{n}^{\mathrm{o}}$ 4.340/2002, o Regulamento da Lei do Sistema Nacional de Unidades de Conservação da Natureza (SNUC), a chamada Lei do SNUC, que determina em seu Artigo 14 ser função do IBAMA estabelecer roteiro para elaboração dos planos de manejo das diferentes categorias de UC, sendo que tais roteiros têm que compreender basicamente:

a) diagnóstico; 
b) zoneamento;

c) programas de manejo;

d) prazos de avaliação e revisão e etapa de implementação.

A estrutura do plano de manejo deve conter, aqui descrito resumidamente: diagnóstico, caracterização da RPPN, da propriedade e da área do entorno, envolvendo levantamento das condições de clima, relevo, geologia, geomorfologia, espeleologia, vegetação, fauna e flora e de patrimônios históricos e naturais; possibilidades de conectividade com outras UCs, declaração de significância, planejamento, objetivos específicos do manejo, zoneamento e um cronograma de atividades e custos.

Destacamos aqui, também de forma resumida, sobre o importante item da visitação, que envolve turismo científico e turismo propriamente dito. Este item é para os casos onde a visitação já ocorre ou será implantada. Deve ser descrito o que está sendo realizado na RPPN, nos casos onde já ocorre a visitação, e como as atividades são desenvolvidas, avaliando a sua pertinência. O empreendedor deve apontar as medidas adotadas para o manejo do impacto da visitação.

Caso haja interesse do proprietário em implantar o uso público (que inclui educação ambiental) na RPPN, deve ser feito o levantamento das potencialidades para visitação (com objetivos turísticos, recreativos e educacionais), abordando:

- $\quad$ iniciativas educacionais e educativas desenvolvidas na UC e na área do seu entorno; indicar a existência de parcerias e programas de capacitação para a condução das iniciativas de educação ambiental.

- avaliação de suas potencialidades e adequação para a visitação, considerando os dados levantados pelo profissional responsável por esse tema ou a partir de dados já existentes, e avaliar os riscos para a integridade do patrimônio, no caso da visitação ser implantada em um ou mais sítios.

- apontar aspectos culturais possíveis de serem utilizados no programa de visitação 
- avaliar se há fluxo de turistas/visitantes na RPPN e na área do seu entorno, freqüência e épocas de maior e melhor visitação.

- quando couber, discorrer sobre a existência de populações tradicionais e/ou indígenas no entorno da UC, e como tais informações poderiam ser utilizadas no programa de visitação, para o seu enriquecimento.

- fazer levantamentos dos atrativos naturais que ocorrem na área, como vales encaixados, morros e picos, cachoeiras, aspectos pitorescos ou mosaicos da vegetação, encostas rochosas, trilhas naturais na mata ou em campos e outras formas de vegetação natural, áreas planas para acampamento, mirantes naturais ou locais próprios para sua instalação, margem de mata própria para colocação de torres para observação de sua estrutura, trechos da mata que permitam colocação de trilhas suspensas, rios, riachos ou lagos e lagoas próprios para banho e/ou para observação de aves e outros grupos da fauna, entre outros atrativos.

- coletar dados para subsidiar as medidas de manejo do impacto da visitação e a metodologia proposta, que deverão constar do programa de visitação a partir da implantação das atividades.

Com relação aos custos das colônias da AFPESP, já explicitamos no capítulo anterior, a entidade apresentou uma planilha de custos totais de 2007 com cerca de dez mil reais de superávit, o que somente é possível por conta do que seus diretores afirmam desenvolver “modernas técnicas de gerenciamento” dentro de “um ambiente familiar” e cujos diretores e coordenadores trabalham de forma voluntária e sem nenhum tipo de remuneração. Mesmo assim as colônias acabam necessitando de um repasse de cerca de 20\% para garantir o padrão de hotelaria dentro da realidade do funcionalismo público.

Nas unidades mais recentes construídas ou reformadas são em geral destacadas três comissões: a primeira que estuda qual seria a melhor sistemática de administração da obra, se por empresa contratada ou gerenciada pela Coordenadoria de Obras; a segunda comissão responsável pelo acompanhamento das licitações e pelo desenvolvimento da obra; e uma terceira comissão de acompanhamento de obras incluindo coordenadores e funcionários da associação, enfim um esforço da entidade para garantir transparência e qualidade. 
Deve ficar claro dessa maneira que mesmo uma instituição com um superávit financeiro dessa monta e do voluntariado de parte dos associados ligados aos cargos de direção e coordenação, há a necessidade de subsidiar os custos de hospedagem do associados, devemos reafirmar que a entidade oferece um ótimo padrão de hospedagem e boas soluções de ocupação do território. Mais ainda, há uma facilitação de pagamento que geralmente possibilita o parcelamento em até cinco vezes, um sistema de sorteio eletrônico buscando dar transparência, confiabilidade e rapidez ao disponibilizar os resultados dos sorteios. Uma das estratégias para otimizar os custos, fica por conta de não haver mais sorteios em algumas colônias no mês de Julho, como já ocorre nos meses de baixa temporada, o que vem garantindo em quase $100 \%$ a taxa de ocupação das colônias ${ }^{65}$, a alta rotatividade de hóspedes garante a minimização dos custos.

Recordamos ainda que a AFPESP possui poucos subsídios oriundos do poder público, como doações de alguns terrenos e isenção de alguns impostos. Como também já descrevemos, o SESC consegue manter seu ótimo padrão de hotelaria, por ser subsidiado por lei exclusiva de arrecadação de imposto via sindicato patronal, que entrementes vem buscando nos últimos anos se livrar dela, o que obviamente deve levar a uma queda no padrão oferecido ou então um aumento de custos para o usuário, distanciando ainda mais a entidade de classes com menor poder aquisitivo.

Vamos agora nos deter com maior profundidade na análise dos custos das colônias de sindicatos no município de Praia Grande, que não dispõem das mesmas experiências e dos mesmos recursos das instituições anteriormente analisadas.

Como já foi explicitado no capítulo 1, o levantamento principal foi feito na colônia de férias do Sindicato dos Fabricantes de Brinquedos e Instrumentos Musicais, no município de Praia Grande nas duas primeiras semanas de janeiro de 2006. Os dados levantados incluíram os gastos com salários, manutenção, alimentação dos hóspedes e higienização, sendo que das receitas foram contabilizados os valores de estadia excetuando os gastos com o restaurante e o bar (lanches, sorvetes e bebidas a parte das refeições já incluídas na diária).

\footnotetext{
${ }^{65}$ Folha do Servidor, Abril e Agosto de 2007, nºs 173 e 177.
} 
Com ele foi possível vislumbrar as diferenças entre as diversas organizações no que se refere à forma de gerir o empreendimento. Como já discutimos, ao compararmos os valores de estadia versus a qualidade das acomodações, aparecem diferenças significativas entre as instituições. As colônias de sindicatos de trabalhadores apresentam valores menores, porém oferecendo serviços e estrutura de qualidade inferior quando comparadas com a AFPESP e o SESC.

No caso em estudo, o da colônia do Sindicato dos Brinquedos, esta imnstituição sofre há mais de uma década com uma forte queda do número de trabalhadores e conseqüentemente do número de sindicalizados. Fato decorrente desde que o país abriu suas portas a importação de brinquedos e artefatos musicais à concorrência internacional, sobretudo com os fabricantes chineses, concorrência bastante desleal, implicando diretamente, de forma negativa no número de trabalhadores que freqüentam a colônia e conseqüentemente em maior dificuldade para a manutenção.

Inaugurada em 1949, a sede da colônia foi comprada pelo sindicato na década de 1960, nos anos de 1990 passou por reformas e ampliação, mas por conta das mazelas do mercado o investimento mostrou-se pouco promissor. Os recursos da colônia são oriundos das contribuições sindicais, que por sua vez é composta pelo imposto sindical, pela taxa assistencial e pela mensalidade, dos valores da diária além do bar. A prefeitura isenta a colônia de pagamento de taxas e impostos.

A administração fica a cargo da presidente da entidade Maria Auxiliadora que esta no movimento sindical há vinte anos, passou por diversas campanhas salariais e atravessou um dos piores momentos quando os produtos do mercado internacional invadiram o país, principalmente os brinquedos a preços muito abaixo dos nacionais, conseqüentemente destruindo muitos postos de trabalho.

Em entrevista a sindicalista, demonstrou grande envolvimento com o funcionamento da colônia, com bem menos recursos do que outras entidades a presidente 
procura primar pela regra e pelo asseio do espaço; nos finais de semana, passa horas conversando com os associados e outras lideranças sindicais sobre assuntos pertinentes ao movmento. Facilita a organização de grupos sindicalizados do interior de São Paulo a um preço bastante popular, ao custo de noventa reais o final de semana com alimentação e transporte incluído. São de fato, para trabalhadores e seus familiares, rara oportunidade, afinal, poucas vezes ou nenhuma vez foram à praia.

A colônia possuía então 25 quartos (houve uma reforma ampliando para 30 quartos) podendo acomodar até cem pessoas ao mesmo tempo, apesar de não haver uma estrutura adequada para esta demanda. Isto fica claro, sobretudo pelo restaurante que não suportaria a freqüência de todos ao mesmo tempo. Nem mesmo há estacionamento suficiente para esta demanda.

De qualquer forma, no mês em que foi dedicada esta pesquisa (Janeiro/2006), com exceção dos dias em que fora comemorado o reveillon, afinal a data de maior procura e que distorceria sobremaneira o levantamento estatístico sendo um dos pouquíssimos períodos em que não ocorreria déficit, a freqüência da colônia nunca superara o número de 30 visitantes por semana, número que cai de forma drástica nos meses de baixa temporada (cerca de dez visitantes por semana ou menos) ${ }^{66}$.

Pelos valores cobrados a diária, o associado tem direito além das acomodações, são quartos para até seis hóspedes, banheiro e ventilador de teto, com roupa de cama, café, almoço e janta, salão de jogos, uso da piscina, da aparelhagem de karaokê e da televisão comunitária, não há aparelhos nos quartos. Ora a isso se remete uma considerável despesa com alimentação, lavanderia, faxina diária e manutenção com a piscina.

Como podemos observar no quadro abaixo, há um número bastante reduzido

\footnotetext{
${ }^{66}$ Os dados referentes a esse levantamento foram possíveis através das entrevistas gravadas junto à presidente do Sindicato: Maria Auxiliadora dos Santos, que também é vice-presidente da FEQUIMFAR.
} 
de funcionários e que diminuem mais ainda na baixa temporada, o zelador e gerente é o responsável o ano todo pela colônia, faz a compra da alimentação quase diariamente nos dias de grande movimento e a manutenção básica geral. Os outros funcionários ficam mais fixos às suas funções, mas todos fazem o atendimento do bar. Na baixa temporada o número de funcionários é reduzido de sete para apenas três, de acordo com a administração é impossível manter o quadro o ano todo. O bar não é terceirizado diferentemente do que ocorre em outras colônias, os preços praticados são bastante populares, mas não há um consumo em grande escala como o consumo de bebidas ou sorvetes, afinal refere-se a um setor do operariado que não recebe a melhor das remunerações, de forma que a contribuição do bar como fonte de renda não é de grande monta.

Considerando uma média de 120 visitantes/mês, sendo que 60 são pagantes, para cinco diárias a 25 reais, chegamos a uma estimativa de 7.500 reais de arrecadação para um custo total de 8.950,00 reais (despesas com as refeições, salários e contas de consumo), temos então um déficit de 1.450,00 reais. Isto se refere ao mês de janeiro, um dos mais movimentados, ficando fácil perceber que o déficit é anual, mesmo contando com menos despesas, como por exemplo, em relação aos funcionários temporários e aos menores gastos com despesas gerais, sem ainda, no entanto deduzir a receita do bar que não obtivemos acesso, mas que não chega a ser relevante a ponto de proporcionar lucro.

Custo geral da colônia de férias do Sindicato dos Trabalhadores das Indústrias de Brinquedos e Instrumentos Musicais - Janeiro de 2006 (excetuando o reveillon)

\begin{tabular}{|l|l|}
\hline Função & Salário em reais \\
\hline zelador & 900,00 \\
\hline Auxiliar de zelador & 600,00 \\
\hline Cozinheira chefe & 600,00 \\
\hline Auxiliar de cozinha & 350,00 \\
\hline 03 funcionários de limpeza & $1.050,00$ \\
\hline & \\
\hline Contas de consumo & \\
\hline água & 400,00 \\
\hline eletricidade & 800,00 \\
\hline telefone & 50,00 \\
\hline manutenção geral & 300,00 \\
\hline & \\
\hline Despesas com alimentação (considerando & \\
\hline
\end{tabular}




\begin{tabular}{|l|l|}
\hline $\begin{array}{l}\text { 120 hóspedes para Janeiro, em um total de } \\
600 \text { refeições para cada período, o valor de } \\
\text { custo é de cálculo aproximado) }\end{array}$ & \\
\hline café da manhã $-1,50$ per capita & 900,00 \\
\hline Almoço - 2,50 per capita & 1500,00 \\
\hline Janta - 2,50 per capita & 1500,00 \\
\hline & \\
\hline Total Geral & $8.950,00$ \\
\hline
\end{tabular}

Na Praia Grande, muitas outras colônias continuam a serem administradas diretamente pela entidade sindical, no entanto, já há alguns anos começou um processo de terceirização da administração em alguns estabelecimentos. Como exemplo, temos a colônia da FEQUIMFAR, situada na Avenida dos Sindicatos, é administrada por um escritório ${ }^{67}$, que vem se especializando neste tipo de serviço, no entanto sempre permanece fixo um diretor que supervisiona e se responsabiliza pelos eventos. A presença deste é fundamental principalmente para o trabalhador que vem de longe e sente a necessidade de encontrar alguém que seja da liderança, afinal sempre acaba sendo um espaço para prática de políticas.

. $\quad$ No entanto, apesar de contar com uma estrutura um pouco melhor há televisores em todos os quartos, salão para reuniões e refeitório com boa estrutura, inclusive contando com uma nutricionista. O líder sindical ${ }^{68}$ responsável pela colônia corrobora as mesmas preocupações com a presidente do Sindicato dos Brinquedos: no geral a colônia chega a gerar muito prejuízo. Em geral procuram várias formas de minimizar o problema como organizar excursões de trabalhadores e seus familiares, grupos da terceira idade e encontros sindicais, intercâmbio com sindicatos de outros países, principalmente via Mercosul, trazendo trabalhadores da Argentina, o problema é que todas as outras colônias, mais de sessenta colônias de sindicatos da Praia Grande, buscam a mesma saída.

Sindicatos mais poderosos podem sem dúvida garantir melhores relações de custo e

\footnotetext{
${ }^{67}$ A.F. Administração de Colônias de Férias (Restaurante, Manutenção, Limpeza e Segurança), Av. dos Sindicatos, 163, Vila Mirim, Praia Grande. Adalto Santos Gerente Administrativo.

${ }^{68} \mathrm{O}$ sindicalista referido é o Primeiro Secretário da FEQUIMFAR Edison Dias Bicalho.
} 
benefício, a própria FEQUIMFAR, ligada ao setor sucroalcooleiro é um exemplo, outros sindicatos como o dos Comerciários e o dos Vendedores, também com colônias na Avenida dos Sindicatos, oferecem estruturas de alto padrão dentro do segmento, inclusive com quartos diferenciados como suítes, é claro que nesses casos poucos trabalhadores têm de fato acesso a esse tipo de serviço, na verdade sendo muitas vezes de acesso apenas a uma "elite sindical”.

Não abordamos aqui a potencialidade turística do trabalhador de acordo com seus ganhos salariais, mas é evidente ser questão extremamente relevante, usuários das colônias do SESC, são em geral de um extrato social com ganhos médios, funcionários públicos, mesmo que em alguns setores viram seus salários serem dilapidados, como ao exemplo dos professores, ainda possuem ganhos que possam garantir uma boa viagem, mas com bastante esforço e planejamento. Outros segmentos de trabalhadores apresentam dificuldades gigantescas para empreender três ou quatro dias de estadia em uma colônia de férias.

Logo nas primeiras entrevistas que pude realizar junto a alguns líderes sindicais trabalhistas sobre o assunto colônia de férias várias questões logo surgiram: que tipo de colônia quero oferecer ao meu associado? Que tipo de colônia o associado pode pagar? De que forma pode-se evitar que as colônias nos dêem prejuízo? Ou ao menos não dêem tanto prejuízo?

De fato, colônias de férias de trabalhadores não foram criadas para darem lucro, mas não podemos deixar de afirmar que ao menos devem ser encontradas formas de torná-las sempre sustentáveis, e não um ônus, pois dessa forma deixarão de ser um ganho do trabalhador. Pensando nessas questões é que no capítulo a seguir é apresentado um desenho do futuro do sindicalismo no Brasil bem como de seu envolvimento ligado às questões das contribuições sindicais, sua ligação com o Estado e sua propositura ao assistencialismo. Acreditamos que com o que foi desenhado até o momento, principalmente quanto a estrutura física e administrativa dos diferentes sistemas de colônias de férias, podemos afirmar que as formas de Associações, além de oferecerem um bom padrão de hospedaria, dentro de um segmento chamado de "turismo social”, apresentam boas soluções de 
ocupação do território, acompanhando as obrigatoriedades legais de ordenamento do solo, leis de zoneamento, de conservação e sustentabilidade, seriam então as Associações melhores organizações do que os sindicatos, para esses fins.

Pois então é nos sindicatos em que reside uma maior necessidade de se prestar atenção como a instituição que deveria melhor desempenhar o papel de representar o trabalhador, inclusive nas questões ligadas ao seu lazer. Os sindicatos no Brasil detêm um expressivo número de colônias de férias, não apenas no litoral paulista, mas como também em outros estados da federação, são também atores ligados às dinâmicas territoriais e merecem bastante atenção. 


\section{CAPÍTULO 5: ASSOCIATIVISMO OU SINDICALISMO?}

De acordo com Johson, existem três formas de associações: as coordenadas de modo imperativo, as diferenciais e as voluntárias ${ }^{69}$. Certamente, nesse estudo são as voluntárias que nos interessam diretamente. Podem ser definidas como um grupo, ou organização, no qual pessoas podem ingressar ou sair livremente, que está isenta de controle externo, e cujas finalidades, objetivos e métodos cabem aos membros determinar. As associações assumem formas tais como clubes esportivos informais, grupos de igreja, de melhoramentos de bairros a agremiações nacionais e políticas. Sua formalidade depende da estrutura e finalidade, organizadas em torno das necessidades emocionais, espirituais ou sociais de seus membros, são muitas vezes consideradas de importância fundamental para a democracia.

A associação tem origem por volta da primeira metade do século XIX, com a revolução industrial despertando a liberdade contratual e a não intervenção do Estado, com isso os indivíduos menos favorecidos passaram a se organizar pelos seus interesses. Com o tempo

${ }^{69}$ Dicionário de Sociologia, Ed. Zahar. 
as associações contribuíram para o surgimento das cooperativas, que em muitos aspectos são bastante semelhantes às associações, no entanto, as cooperativas acabaram por desenvolver características bastante peculiares e passaram até mesmo a serem vistas como doutrina. A grande diferença está no fato de as cooperativas objetivarem desempenhar, em benefício comum, determinada atividade econômica. Nos Estados Unidos, nos anos 1930, surgiram as cooperativas de consumo, como as distribuidoras de mercadoria, de telefone, de seguro, de saúde e de recreação, em uma época em que se pensava viver uma quase utopia realizada, de forma que um cidadão pudesse consumir apenas em cooperativas ${ }^{70}$

Para diferenciarmos as associações das cooperativas no Brasil, foi utilizado como referência um quadro comparativo elaborado pelo SEBRAE. Ambas são sociedades civis sem fins lucrativos sendo que apenas as cooperativas possuem caráter comercial, sendo que a prestação de serviços de interesse cultural está mais diretamente ligada às associações. A representação legal de ambas é feita mediante a autorização do estatuto social. Enquanto as cooperativas praticam qualquer ato comercial, as associações podem ou não comercializar. Nas associações seus dirigentes são reembolsados de acordo com as despesas realizadas no desempenho de suas funções, nas cooperativas os dirigentes fazem retiradas mensais. A escrituração contábil das associações é simplificada e objetiva, é isenta do imposto de renda e pode ser isenta de outros impostos e taxas. Já as cooperativas devem recolher, sempre que couber, o imposto de renda na fonte, pagando todos os outros impostos e taxas cabíveis. Os superávits das associações devem ser aplicados em suas próprias finalidades, havendo o rateio do superávit nas cooperativas. Ambas podem constituir órgãos de defesa e representação.

Essa discussão é fundamental para o presente trabalho na medida em que se pretenda pensar sobre políticas públicas de fomento para as colônias de férias. Ora, tanto as cooperativas, as associações e os sindicatos podem e devem desenvolver esse tipo de trabalho junto à sociedade, mas são as associações as mais indicadas. Historicamente no Brasil a associação tem desempenhado grande trabalho de qualidade ao oferecer lazer para o associado. Juntas, somente no estado de São Paulo, oferecem dezenas de colônias para

\footnotetext{
${ }^{70}$ Diva Pinho, Dicionário de cooperativismo, USP, 1962.
} 
trabalhadores, sempre com valores de estadia e qualidade bastante compatíveis com o salário dos trabalhadores de média e baixa remuneração. Algo para se refletir é que as associações são mais isentas de “confusões ideológicas”, quando comparadas aos sindicatos, ou seja, correspondem principalmente às finalidades que foram constituídas. Os sindicatos já não estão livres disso.

Ainda quanto às questões sobre o associativismo é interessante refletirmos sobre a obra de Richard Sennet que ensaia sobre a chamada "flexibilidade" do atual estágio do capitalismo que faz com que o trabalhador assuma riscos continuamente, característica de uma sociedade impaciente, que se concentra no momento imediato. A narrativa da vida das pessoas escapa ao próprio controle, surge até mesmo um sentimento de perda de controle do tempo. Diminuem-se as amalgamas de uma vida social mais comunitária e de dedicação à família ${ }^{71}$.

Dentro do processo fordista de produção havia a possibilidade de associações e sindicatos afirmarem suas próprias exigências, o que de certa forma poderia degradar o trabalho pelo seu aspecto rotineiro, mas, ao mesmo tempo, garantia a composição de uma vida. Para Sennet:

“A repulsa à rotina burocrática e a busca da flexibilidade produziram novas estruturas de poder e controle, em vez de criarem as condições que nos libertam. O sistema de poder que se esconde nas modernas formas de flexibilidade consiste em três elementos: reinvenção descontínua de instituições; especialização flexível de produção; e concentração de poder sem centralização. Os fatos que se encaixam em cada uma dessas categorias são conhecidos da maioria de nós, nenhum mistério; já avaliar a conseqüência deles, é mais difícil” ${ }^{72}$.

A identidade com o trabalho torna-se fraca e as pessoas ficam expostas ao risco e ao “sempre começando de novo”, que gera ansiedade, dilui a auto-estima e fragmenta famílias

\footnotetext{
71 A corrosão do caráter, conseqüências pessoais do trabalho no novo capitalismo, 2005, Ed. Record.

${ }^{72}$ Ibdem, p.54.
} 
e comunidades. Em um passado não muito distante, muitas das grandes empresas apoiavam a vida social dos funcionários, inclusive com benefícios para a educação e o lazer. Sennet não propõe um retorno à segurança do trabalhador no esquema fordista e nem ao ascetismo de Max Weber, mas de como organizar a história de nossas vidas dentro de um capitalismo que nos deixa à deriva.

"Lugar é geografia, um local para a política; comunidade evoca as dimensões sociais e pessoais de lugar. Um lugar se torna uma comunidade quando as pessoas usam o pronome 'nós'”73. É possível que Sennet tenha razão quando diz que há um retorno de um "nós" fictício à vida, pois após a grande avalanche neoliberal, várias formas de organizações populares resistiram e se reorganizam em várias esferas da vida, e isso, também é obviamente uma questão de politização. É nos sindicatos, também originado a partir das associações, que essa politização se acentua.

Foi pensando sobre a necessidade de elaborar políticas públicas voltadas para o turismo social e especialmente para as colônias de férias, é que se faz necessário abrir um diálogo sobre as tendências do sindicalismo para o século XXI, uma vez que são essas entidades responsáveis em grande parte pelo fomento ao lazer do trabalhador na atualidade. A discussão é baseada principalmente sobre alguns trabalhos de estudiosos brasileiros, mas, também em entrevistas e consulta de artigos realizadas junto a FEQUIMFAR (Federação dos Trabalhadores nas Indústrias Químicas e Farmacêuticas do Estado de São Paulo) entidade ligada à Força Sindical.

A discussão em questão pode ser dividida em duas partes: na primeira, sobre as influências das novas formas de relação de produção global, sobre seus efeitos no trabalho e conseqüentemente sobre a estrutura sindical. É possível apontar tendências sobre o futuro da sindicalização no Brasil e no mundo, ainda que sempre tenhamos em mente sobre as particularidades e complexidade de cada nação, sobre seu momento econômico e sua realidade social. Na segunda parte, o foco refere-se às novas formas da atividade sindical, sobre o empenho para conquistas de benefícios ao trabalhador e das relações com

\footnotetext{
${ }^{73}$ Ibdem, p.165.
} 
movimentos sociais e outras formas de atuação junto ao trabalhador.

Mesmo que a discussão reflita apenas um recorte da realidade global e brasileira é bastante plausível dizermos que há uma “crise sem precedentes do sindicalismo”, essa crise tornou-se evidente a partir do momento em que a precariedade das relações de trabalho, a perda de direitos e aumento da pobreza tornou-se bastante evidente por todo o mundo. Vale ainda ressaltar que os apontamentos, aqui levantados, permite indagarmos, não somente sobre o futuro do sindicalismo, mas, principalmente das novas formas de relações do trabalho e de novas formas de organização dos trabalhadores, que visem de alguma forma sobre a melhoria das condições de vida do trabalhador e de sua família.

Considerando a globalização na sociedade contemporânea ser tema de discussões controversas é consenso, que vivemos um momento de mudanças significativas. Na visão de Hirst e Thompson (1998) há de fato uma tendência à internacionalização crescente. Os referidos autores buscam basicamente comprovar que a globalização "é basicamente um mito”, não estaria, pois, ocorrendo um novo sistema econômico ${ }^{74}$. O que nos é mais importante refere-se à idéia do enfraquecimento da governabilidade dos Estados nacionais: haveria sim muitas possibilidades de governabilidade econômica, isso ocorreria pelos acordos entre os Estados avançados que criam agências de regulação internacional, pelo controle de amplas áreas econômicas e pela criação de políticas de nível nacional que equilibram a cooperação e a competição entre as empresas e os principais interesses sociais ${ }^{75}$.

Dentro das transformações contemporâneas, Harvey (1992) nos leva à idéia de um novo momento dentro do atual sistema econômico, procura compreender a passagem de uma economia fordista-keynesiana para uma pós-moderna (pós-industrial) de acumulação flexível, desenvolve uma análise sobre economias de nações distintas como a dos EUA, das nações industrializadas da Europa e também da Ásia. Harvey procura demonstrar que as transformações em cada uma destas economias seguem ritmos e padrões particulares, ainda

\footnotetext{
74 Globalização em Questão. Petrópolis: Vozes, 1998, p.14.

${ }^{75}$ Ibdem, p.293.
} 
que demonstrem uma mesma tendência à flexibilização da economia. Em verdade outros e antigos processos sociais e econômicos convivem com os novos. Para Harvey há um crescimento no emprego com relação às atividades do “grupo central” ligados ao trabalho de flexibilidade funcional, mas também indica sobre o crescimento dos empregos de subcontatação de menor especialização ${ }^{76}$.

Castells (1999) foca o desenvolvimento da sociedade informacionalizada, se baseia em diversas análises sobre setores da economia e das estruturas ocupacionais a respeito dos países integrantes do G7. Para ele há um crescimento das atividades "mais claramente informacionais” de maior qualificação, sendo que na outra ponta um crescimento dos empregos de baixa qualificação ${ }^{77}$. Tanto Castells quanto Harvey observam um declínio do nível de emprego das situações ligadas as estrutura médias do mercado de trabalho, o que aqui cabe colocar como reflexão é que essas tendências sobre a estrutura ocupacional do mundo do trabalho vieram apresentando severas influências negativas sobre a sindicalização, sobretudo nos países desenvolvidos e também em países como o Brasil.

A partir dos anos 70 a relação de trabalho vem sofrendo fortes transformações, o setor industrial deixou de ser predominante, sendo substituído pelo setor de serviços, com a reestruturação das empresas e das novas formas de organização houve redução dos postos de trabalho e conseqüentemente novos desafios para a ação sindical. De acordo com Iram Rodrigues (2001) as mudanças na relação entre capital e trabalho, podem ser notadas pela “diminuição acentuada da taxa de conflito, especialmente nos países desenvolvidos, ao mesmo tempo em que os sindicatos trabalhistas sofrem uma perda significativa em suas fileiras ${ }^{\text {78 }}$.

É um novo modelo de relações de trabalho que está sendo anunciado em contraposição com o período tipicamente fordista de padronização, de classes trabalhadoras e de sindicatos fortes. O novo modelo apresenta uma tendência à produção em pequenos lotes,

\footnotetext{
${ }^{76}$ A condição pós-moderna. São Paulo: Loyola, 1992. Parte II p.143/145.

${ }^{77}$ A sociedade em rede. Vol. I, São Paulo, Paz e Terra, 1999, p.239 a 245.

78 Transformações do trabalho e ação sindical no final do século XX: algumas questões, 2001, p.155.
} 
consumo individualizado, diminuição de pessoal das empresas, enfraquecimento do Estado, fim do trabalhador que só sabe “apertar parafusos”, organização do trabalho baseado em equipe e sindicatos mais enfraquecidos. É possível que com este novo modelo, a tendência das ações sindicais seja mais pelas negociações do que pelos conflitos do passado recente. Ainda de acordo com Rodrigues a dispersão geográfica, as formas de terceirização e subcontratação complicaram ainda mais as ações sindicais: "por vezes, em uma mesma seção, e até na mesma função, existam grupo de trabalhadores que seguem ordem de diferentes empregadores com normas diferenciadas no que diz respeito a salários, jornada de trabalho entre outros aspectos”. Talvez a sociedade pós-industrial abra pouco espaço para a ação sindical, embora isso deva ser bem analisado de acordo com cada nação. Nos países centrais parece haver "uma mudança das pessoas na postura relacionada com o trabalho, uma relação "hedonista” em contrapartida da concepção que tinha como matriz a “ética protestante"79.

Em um trabalho de fôlego Leôncio Rodrigues (2002) nos apresenta uma pesquisa com uma gigantesca coleta de dados sobre as taxas de sindicalização nos países desenvolvidos nos aponta tendências a partir de variantes econômicas e políticas que invariavelmente vem derrubando as taxas de sindicalização. EUA, França, Japão, Suíça e Holanda apresentam baixos índices de sindicalização, Alemanha, Austrália, Canadá, Itália e Reino Unido com média sindicalização e Bélgica, Finlândia e países nórdicos com alta sindicalização ${ }^{80}$.

Os fatores de dessindicalização poderiam ser separados em estruturais “de eventos e processos de natureza mais estável, de efeitos de médio ou longo prazo e menos sujeitos ao controle e intervenção deliberada dos vários atores do campo político e sindical” como as mudanças tecnológicas, alterações no mercado de trabalho e nas novas tendências de consumo. E os fatores de tipo conjuntural, que estão no campo do jogo político partidário das leis e instituições sindicais de "situações que podem ser alteradas bruscamente ou (sic)

\footnotetext{
${ }^{79}$ Ibdem, p. 161/162.

${ }^{80}$ Destino do sindicalismo. Editora da Universidade de São Paulo: Fapesp, 2002, p.30.
} 
a curto prazo" ${ }^{81}$. A primeira possibilidade, de caráter econômico, traria uma perspectiva mais negativa para os sindicatos, por outro lado, caso seja um fenômeno de cunho políticoinstitucional as perdas do sindicalismo podem ser recuperáveis, desde que as lideranças sindicais desenvolvam novas estratégias de enfrentamento ao poder empresarial.

Na verdade são muitos os elementos causadores da dessindicalização: fatores tecnológicos como a informatização e a produção flexível teriam provocado deslocamentos, reclassificações e de reorganização empresarial resultando em um novo modelo de trabalho, afetando os sindicatos industriais que haviam se consolidado como os maiores e mais fortes no decorrer do século XX. As empresas responsáveis por tarefas de terceirização são menores e de sindicalização mais baixa. A fragmentação do processo produtivo não levou a uma divisão da unidade de comando empresarial, "o que significa dizer que grupos mais segmentados de trabalhadores passaram a ter pela frente companhias mais poderosas, com comandos e estratégias mais unificadas, com mais poder de fogo anti-sindical”82.

O aumento do trabalho de meio período é outro importante fator de dessindicalização, isso ocorre principalmente com a feminilização do trabalho e com a expansão do setor de serviços. Apesar disso a presença feminina nos sindicatos vem crescendo em alguns países, ainda que a presença masculina seja mais elevada ${ }^{83}$.

As últimas considerações sobre a dessindicalização referem-se aos efeitos das mudanças políticas: partidos de esquerda tenderiam a promover legislações que favoreçam os sindicatos; partidos de direita tendem a baixar as leis que reduzem o poder sindical. Mas, são tendências, "na prática, há tipos diferentes de partidos de direita e de esquerda”. "Governos amigos” como os sociais-democratas aumentam em média 1\% as taxas de sindicalização, “não apenas pelo apoio político mas (sic) também pelas leis que fazem votar nos parlamentos de maioria social-democrata ou socialista a favor dos sindicatos” ${ }^{84}$. Sobre a questão da dessindicalização Leôncio Rodrigues conclui que as análises multivariadas

\footnotetext{
${ }^{81}$ Ibdem, p. 164.

${ }^{82}$ Ibdem, p.179.

${ }^{83}$ Ibdem, p.188.

${ }^{84}$ Ibdem, p.233/239.
} 
“quando parecem comprovar empiricamente alguma relação, freqüentemente ela é contrariada por novos cálculos ou desmentida por novos desdobramentos” ${ }^{85}$.

Armando Boito (2003) nos da outras visões sobre o futuro do sindicalismo, critica a tese "bem aceita e desenvolvida” de ser o sindicalismo um movimento fadado à decadência e a desempenhar um papel de pequena importância no século XXI e de que os fatores de ordem econômica comprometeriam os sindicatos.

De acordo com Boito para falar em crise devem-se considerar as principais regiões econômicas do globo e não apenas sobre os países centrais, em sua visão o que estaria ocorrendo é um refluxo. As análises seriam em sua maioria baseadas em tendências de curto prazo para prognósticos de longo prazo ${ }^{86}$. Questiona se as novas massas de trabalhadores, grupos e setores não irão se sindicalizar argumenta que, no passado fora os menos qualificados, os trabalhadores das indústrias, que depois vieram a apresentar os quadros de maior sindicalização.

Boito salienta ainda sobre o crescimento sindical na esfera pública como fator relevante para o crescimento sindical. Mas podemos contra argumentar com Leôncio Rodrigues sobre a sindicalização do setor público uma vez que, ao mesmo tempo em que deu um novo impulso, trouxe problemas como “abalar as autoridades das centrais sindicais tradicionais, reduzir a legitimidade de suas lideranças, minar sua capacidade de representação ampla da massa de assalariados ${ }^{\nexists 7}$. As ações do sindicalismo público seriam reduzidas, uma vez que a maioria da população "é simpática às ações sindicais que desafiam o poderio do grande capital. Não é o caso de greves do setor público que prejudicam os consumidores e usuários de bens e serviços fornecidos pelo Estado" ${ }^{88}$.

Certamente uma das questões mais difíceis para o movimento sindical responder: Como se adaptar a um novo mundo? Boa parte dos pesquisadores indica a necessidade de um

\footnotetext{
${ }^{85}$ Ibdem, p. 264.

86 A crise do sindicalismo, in: Além da Fábrica, Boitempo Editorial, 2003, São Paulo p.325.

${ }^{87}$ Destino do sindicalismo. Editora da Universidade de São Paulo: Fapesp, 2002, p.110.

${ }^{88}$ Ibdem, p.114.
} 
“sindicalismo transformado para um mundo transformado”. É nesse contexto defendemos a tese de que, uma vez aceito que há uma nova tendência nas relações de trabalho capital e que esta tendência modificou e vem modificando a forma do sindicalismo ser, seja por vias econômicas ou políticas, s sindicatos podem e devem se relacionar com muitas outras questões com o "mundo da vida”, inclusive no que concerne o lazer e a gestão de colônias de férias.

Ramalho e Santana (2003) defendem que já há indícios de novas formas de organização sindical, a nova realidade imposta pela flexibilização da produção e dos mercados, o fim do welfarestate e a supremacia do neoliberalismo teria levado aos “novos fenômenos sociais”, ou a uma "nova questão social" 89 . Talvez vivenciemos o de fato "um entroncamento de crises”, uma crise estrutural e uma crise antropológica ocorrendo, então a "decadência do coletivo" 90 . É nesse contexto que procuramos apoio em Ramalho e Santana, o impacto dessa crise sobre os sindicatos foi grande, mas “nas análises sociológicas o seu peso tem variado conforme a ênfase - otimista ou pessimista - no que se refere à capacidade de reação dos sindicatos aos desafios postos pelo novo cenário”. Os autores defendem que há um momento de crise, inclusive com uma "pane” no discurso sindical, mas entendem também que é bastante plausível relativizar essa crise. A própria idéia de que estaríamos em uma tendência de sair do coletivismo para o individualismo pode ser considerada bastante unilateral. Considerar o coletivismo como um valor moral em si talvez não seja real, “o mais realista seria supor que - à parte os movimentos de mobilização de massas - a maioria dos membros dos sindicatos aderiu à organização coletiva como meio mais eficaz de tornar realidade suas necessidade e aspirações individuais" ${ }^{91}$.

Uma idéia bastante avançada seria de um “sindicalismo tipo movimento social”, aberto às novas demandas, mais internacionalizado e por uma política socialista renovada. Os sindicatos se articulando com outros sindicatos, organizações de bairro e outros movimentos sociais. Para o Brasil, Ramalho e Santana entendem que uma combinação de

\footnotetext{
89 Trabalhadores, sindicatos e a nova questão social, in: Além da Fábrica, Editorial Boitempo, 2003, São Paulo p.13

${ }^{90}$ Ibdem, p.22.

${ }^{91}$ Ibdem, p.27.
} 
rigor analítico com uma perspectiva não-pessimista sobre o sindicalismo poderia ajudar, no país ocorrera uma conjuntura de processos que "permitiu o desdobramento da ação sindical para além do muro das fábricas, associando reivindicações econômicas a questões políticas, participando do processo de redemocratização do país e produzindo um tipo de sindicalismo que procurou romper o atrelamento ao Estado e enfatizou uma prática construída sobre a organização nos locais de trabalho"92.

A orientação sindical alterou-se dos anos 1980 para os anos 1990 de uma prioridade de questão econômica-salarial para a temática da garantia do emprego ou de combate ao desemprego.

Um exemplo recente nos é dado por Souza (2002) focando as transformações recentes do sindicalismo brasileiro analisando a ação do sindicato dos metalúrgicos de Campinas e região diante do desemprego. Sua abordagem envolve o entendimento das diversas teorias que buscam explicar estas transformações recentes: do economicismo, da tese da inevitabilidade, da descentralização produtiva e de forma geral do neoliberalismo, todas buscando uma explicação para a questão do desemprego e de uma diminuição da combatividade dos sindicatos.

O que nos interessa em sua discussão diz respeito a uma suposta "crise do sindicalismo”, em um momento histórico que parece nos indicar pouco espaço de manobra para os sindicatos. Apesar da complexa análise, afinal um sindicato ganha força em detrimento de outro de acordo com os setores produtivos que estão em crescimento, de uma forma geral o chamado sindicalismo combativo dos anos 1980 passou a ser contraposto por um sindicalismo propositivo de caráter mais conciliatório e menos combativo ao governo e empresários. Souza nos alerta dos perigos desta análise simplista afinal a “ representatividade de um sindicato está baseada na categoria e na territorialidade” e “ as diferenças com relação ao setor a ser estudado e às especificidades regionais têm de ser levadas em conta”93 e há ainda um complicador que são as diversas correntes ideológicas

\footnotetext{
92 Ibdem, p.31.

${ }^{93}$ Sindicato dos Metalúrgicos de Campinas e Região diante do desemprego no período de 1990 a 2002. Dissertação de Mestrado do depto. de Sociologia da FFLCH da Universidade de São Paulo, 2005, p.30.
} 
que se formam no interior dos sindicatos além da estrutura hierárquica de centrais, federações estaduais e sindicatos influenciando diretamente na ação de cada grupo.

No estudo de caso, o sindicato dos metalúrgicos de Campinas atravessou uma fase de rupturas e continuidades na prática sindical. A nova diretoria empossada no ano de 1984 buscou uma independência financeira do sindicato e o fim do assistencialismo entre outras medidas. Quanto à questão da independência financeira, significa não depender do Estado ou de empresários, apenas dos sócios, que na visão de Souza estão amarrados ao sindicato através da cobrança do imposto sindical e da taxa assistenciais o que em verdade não representa uma “independência” como também podemos entender através do trecho: “ Em seu discurso de independência financeira, o Sindicato não leva em conta que a sindicalização do trabalhador à entidade continua dependente da representatividade imposta em lei pelo Estado, ou seja, de que é a partir do reconhecimento pelo Ministério do Trabalho, órgão atrelado à máquina estatal, que o Sindicato pode representar o conjunto de todos os trabalhadores de sua categoria e região específicas. Sendo assim, a dependência financeira do sindicato persiste, contribuindo para a permanência do atrelamento da entidade à estrutura do sindicalismo de Estado, que tem como um dos seus pilares as contribuições compulsórias”94.

A tese que consideramos relevante é o caso do fim do assistencialismo sindical, forma considerada enganosa de atrair o trabalhador para o sindicato. Em geral o sócio é atraído por uma série de serviços assistencialistas, o que foge ao objetivo central dos sindicatos. De acordo com Souza ${ }^{95}$ alguns sindicalizados entendem que os serviços do clube e da colônia de férias são resquícios do assistencialismo, servindo de prioridade quando a entidade quer arregimentar novos sócios. E de fato, o clube e a colônia são grandes atrativos ao trabalhador que pretenda se filiar. Há uma conscientização óbvia de que utilizar a rede hoteleira convencional no litoral é bem mais cara do que a hospedagem na colônia.

As questões do assistencialismo ligadas aos movimentos trabalhistas remontam o fim

\footnotetext{
${ }^{94}$ Ibdem, p.44.

${ }^{95}$ Ibdem, p. 47/48.
} 
do século XIX para início do século XX, Gomes (1991) nos mostra que os trabalhadores do Brasil já não eram um todo homogêneo com relação ao tema. Na perspectiva dos socialistas as associações de classes são muito importantes, sendo os direitos políticos o cerne da proposta, a representação político-partidária tendo precedência sobre a participação associativa enraizada nos interesses profissionais. Para os anarquistas as associações de classe deveriam se dirigir para os interesses econômicos e não assumir feições assistencialistas. Para os sindicalistas cooperativistas a articulação em partido político é em princípio afastada, em nome dos direitos sociais e não dos políticos, tinham funções assistencialistas. Os comunistas com uma visão de cidadania política, de um partido com laços sólidos com o movimento sindical de ação reivindicatória tanto quanto por sua ação assistencialista. As lideranças políticas da República (a elite intelectual da época) recusaram todas as propostas dos trabalhadores, colocando um fim a um sindicalismo independente, político, reivindicatório e também assistecialista ${ }^{96}$.

Mesmo que alguns pensem ser errado um sindicato que atue não somente apenas nas questões ligadas ao trabalho fica então a necessidade de se pensar em outras organizações de trabalhadores voltadas para atender a importantes necessidades do trabalhador como o lazer, mas acreditamos no momento ser justamente o sindicato a organização que também pode cuidar disto sem sentimento de culpa, são ações voltadas ao lazer que muitas vezes contribuem para um melhor relacionamento entre as pessoas, e como já estamos tentando demonstrar em estudo de caso, as colônias de férias podem sim representar muito mais do que um espaço para o entretenimento, servindo na ampliação do horizonte de conhecimento do trabalhador seja em atividades conscientizadoras sócio-ambientais, seja no prazer de se conhecer uma outra realidade.

Fica evidente que iniciativas deste tipo tornam o turismo, seja de qual tipo ele for, mais do que apenas o “relaxar”, sendo também um momento para se ganhar conhecimento e novas conscientizações, fica igualmente claro a função social das colônias de férias de trabalhadores contribuindo para uma melhor formação do cidadão, portanto talvez seja bastante interessante despertar a possibilidade de outros projetos envolvendo questões

\footnotetext{
${ }^{96}$ República, Trabalho e Cidadania, p. 74/76. in Corporativismo e Desigualdade. IUPERJ, Rio Fundo Ed.
} 
ambientais, culturais e mesmo políticas.

Muitas das atividades voltadas para o lazer possibilitam um certo retorno político interno à organização sindical. Estas idéias aparecem no discurso de algumas lideranças sindicais já citadas, como por exemplo, a presidente do Sindicato dos Brinquedos ela reconhece a importância social do funcionamento da colônia. Com bem menos recursos do que outras entidades (afinal foi um setor industrial muito abalado com a liberalização econômica) há uma facilitação para que muitos trabalhadores e seus familiares possam deixar suas cidades interioranas e conhecerem, o que ocorre em muitas ocasiões, a praia e o mar ao vivo pela primeira vez na vida. A presidente também costuma utilizar alguns finais de semana para marcar encontros com jovens lideranças sindicais, fortalecendo laços e entendimentos.

Também na colônia do Sindicato dos Químicos no município de Praia Grande, os trabalhadores sempre se encontram e fazem questão da presença de alguma liderança. Sindicalistas do sindicato dos químicos da baixada santista, da região metropolitana de São Paulo e do interior paulista realizam encontros para discutir determinados temas. A colônia poderia ser também utilizada como forma de envolvimento do sindicato com outras parcelas da sociedade, na verdade, buscando a melhor manutenção desses espaços, são abertas vagas para aposentados e estudantes (como por exemplo, do projeto "o interior vai a praia”) pelos mesmos preços populares, seria o caso de se pensar em estratégias de esclarecimento à população da importância da atividade sindical, tornando o uso do local mais do que apenas para o lazer.

Os movimentos sociais ganham força, dentro das possíveis novas estratégias, de acordo com Beynon (2003), o "aumento da receptividade para com as novas formas de organização por parte de alguns sindicatos tem sido, em certa medida, influenciado pelo duro revés no número de seus membros, trazido pelo fechamento das fábricas e pelo desenvolvimento dos novos tipos de trabalho, formas de contratação e condições de 
trabalho"97.

De fato, muito do que já se teoriza a respeito das novas adaptações do sindicalismo frente às transformações contemporânea - maior integração sindical, associação à movimentos sociais, internacionalização, conquista de benefícios - podemos notar em parte nos discursos e nas ações notificadas nos periódicos da FEQUIMFAR. Como uma federação a FEQUIMFAR, ligada à Força Sindical, abriga cerca de cem mil trabalhadores em todo o Estado de São Paulo, os setores mais representativos são o da fabricação de álcool e açúcar, o que mais emprega com cerca de 25 mil trabalhadores, o farmacêutico, de fertilizantes e dos plásticos.

Diversos temas como as negociações, conquistas e outras preocupações sociais e ambientais são veiculadas no periódico Jornal da Federação. São temas como convenções reivindicando fornecimento gratuito de medicamentos, assistência médica, vale-compras, cursos profissionalizantes, redução da jornada e o respeito aos direitos das mulheres, sobre os benefícios da luta pelo contrato coletivo nacional, envolvimento em conferências internacionais. As questões ambientais são de grande relevância, não apenas no chão de fábrica onde em certos lugares ainda há os riscos de trabalho pelo uso de produtos como o benzeno, mas também por questões econômicas e ambientais fundamentalmente no que se refere ao uso do álcool combustível, um setor em franca expansão tanto no mercado interno como para exportação.

A renovação do sindicalismo de fato já está ocorrendo, a atual história pode ser notada no discurso: "Muitas entidades sindicais mantêm parcerias e convênios com escolas e universidades, algumas realizam e promovem diversos cursos e treinamentos profissionalizantes. Isso tudo, além da produção de programas de televisão com dicas e informações sobre o dia-a-dia sindical. Existem também parcerias com iniciativas privadas, na área da saúde, onde são oferecidos planos, descontos em exames e medicamentos. Na área financeira, existem os convênios com bancos e instituições, para realização de

97 O sindicalismo tem futuro no século XXI?, in: Além da Fábrica, Editorial Boitempo, 2003, São Paulo p.63. 
empréstimos. Isso tudo e muito mais: turismo, lazer, esporte, são algumas áreas em que as entidades sindicais atuam”, 98 .

É defendida a idéia da um “sindicato cidadão”, que se preocupa com os trabalhadores de todo o país, com os aposentados e com os desempregados. Mas há também um reconhecimento das dificuldades para o sindicalismo contemporâneo, os sindicatos entendem a dificuldade de realização do movimento, como luta verdadeira. Sobre a perda de força da reforma estrutural sindical corporativista corroboram ao menos em parte as teses de Boito (1991) em seu "O sindicalismo de Estado no Brasil”: "No Brasil atual, a constituição jurídica é, no tocante à organização sindical, contraditória: estabelece, ao mesmo tempo, a dependência e a autonomia dos sindicatos diante do Estado. Ocorre que a

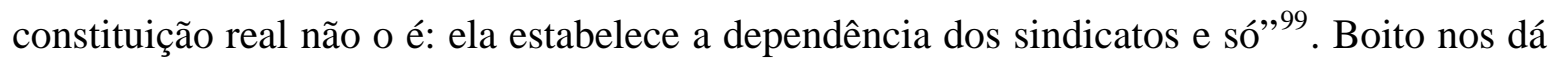
alguns exemplos no decorrer de sua pesquisa como nenhuma corrente sindical representativa de fato lutou pela autonomia sindical, pelo contrário o que sempre imperou foi a busca à legalização pelo governo na manutenção do corporativismo.

Mas Boito também via algumas boas possibilidades com a elaboração das leis complementares. A atual questão da taxa negocial, que está na pauta das discussões sindicais, parece ser um bom exemplo, uma taxa que de certa forma "afrouxa” o controle do Estado sobre o sindicato ${ }^{100}$.

Vale destacar a compreensão do corporativismo no Brasil de Leôncio Rodrigues (1990): “Mas, uma vez montado o sistema corporativo, múltiplos segmentos da sociedade passaram a ter seus interesses vinculados à continuidade da nova instituição”, gerou

\footnotetext{
98 Jornal da Federação n. 82, p.8, 2005.

${ }^{99}$ O sindicalismo de Estado no Brasil: uma análise crítica da estrutura sindical. Campinas, SP: Editora da UNICAMP; São Paulo: HUCITEC,1991, p.58.

100 “A taxa negocial tem esse nome porque é negociada em assembléia pelos trabalhadores. Ela vai ser o principal sistema de custeio das entidades sindicais, pois se elas não tiverem como se sustentar, das duas uma: ou deixam de existir ou teriam que ter o rabo preso com os patrões. Nos dois casos, o movimento sindical estaria comprometido, e com ele a democracia. A taxa negocial também simplifica o método atual. Eram quatro contribuições que se tornam apenas uma. Vai custar menos e vai ser mais simples para o cidadão contribuir com o sindicato. Antes, o desconto chegava a mais ou menos $27 \%$ do salário de um mês. Agora, deve ficar entre 12 e 15\%”. www.fsindical.org.br.
} 
milhares de empregos, não só para as pessoas de "boa família”, mas também para as classes média e baixa. E ainda “o corporativismo serviu igualmente aos membros das classes populares que conseguiram um emprego de “dirigente sindical” nas centenas de sindicatos então criados e sustentados pelo poder público” ${ }^{101}$. Por outro lado, infelizmente foi algo que ficou certamente restrito a uma parcela apenas da sociedade. Voltando às entrevistas com dirigentes da FEQUIMFAR o uso atual das colônias de férias ou mesmo de certos benefícios, tem se tornado em muitos sindicatos de uso restrito para a classe dirigente. Em geral os dirigentes conseguem flexibilizar seu horário de trabalho, podendo se programar melhor para o lazer, além disso, seus salários na média são maiores do que o associado padrão.

Ampliando ainda mais a discussão Leôncio Rodrigues parece ver benefícios no corporativismo: “Olhando a questão mais concretamente, do ângulo das relações de forças uma dada conjuntura achamos que em algum momento o sistema foi mais favorável aos empregadores, e, em outros, aos empregados”102. De certa forma isso é corroborado na visão de alguns sindicalistas como podemos notar neste trecho extraído do Jornal da Federação "citando algumas das conquistas do movimento sindical podemos destacar a própria criação da CLT e a Previdência Social. Vindo posteriormente o direito dos trabalhadores e a Participação nos Lucros e Resultados das Empresas”"103. Sabemos que sobre essas “conquistas”, como a criação da CLT, somente foram possíveis dentro do aparato do corporativismo sindical de Estado.

Buscando algumas conclusões parece bastante consensual que as transformações que ocorreram entre as relações de capital e trabalho nas últimas décadas, sejam elas de caráter econômico ou político, interferiram profundamente na estrutura e no modo de agir do sindicalismo. O desemprego retirou grandes fileiras de trabalhadores, os novos setores de crescimento da economia ainda não viram um verdadeiro despertar de seus trabalhadores para o sindicalismo. O sindicalismo ligado ao setor público ainda guarda dificuldades para

\footnotetext{
101 O sindicalismo corporativo no Brasil, in Partidos e sindicatos. Escritos de sociologia política, Editora Ática, 1990, p. 65.

102 Ibdem, p.66.

103 Jornal da Federação n. 82, p.8, 2005.
} 
se tornar mais movimento, pois afetam serviços essenciais à população. As lutas passaram a ser mais pela garantia do emprego, mas também por conquistas como benefícios.

Quanto à continuidade da ação ou reação sindical destacamos mais uma vez os pensamentos de Leôncio Rodrigues "os dirigentes sindicais, obviamente, tem consciência da dimensão dos perigos que ameaçam a própria sobrevivência da organização sindical... e que põem em risco também seus empregos,”... ${ }^{104}$.

Como saída para esses “perigos” haveria duas propostas: Coletivas - os sindicatos deveriam voltar-se para novos grupos de trabalhadores como os jovens, que trabalham no setor mais crescentes que é o de serviços e também para as mulheres. Organizatória - de fusão dos sindicatos que em geral não tem trazido bons resultados. Individualistas - os sindicatos procuram aprofundar e diversificar serviços oferecidos a preços especiais, tais como: cursos, empréstimos, cartões de crédito, consultoria em assuntos profissionais sobre direitos dos empregados as seguridades sociais, impostas de renda, negociação do contrato individual do trabalho e outros assuntos equivalentes. Mas Rodrigues alerta: “o engajamento nesse tipo de atividade não está isento de certos riscos”105 como afastar-se de sua função de pressão e negociação e a arriscar-se a prejuízos financeiros. As colônias de férias de sindicatos infelizmente tem mostrado prejuízos, mesmo com os pagamentos das diárias, muitos sindicatos têm de financiar os prejuízos, por isso, alguns sindicatos já vem terceirizando o controle administrativo de sua colônia. É curioso notar nesse caso que, os próprios sindicatos tem feito uso de práticas de gestão que de certa forma contribuíram para as atuais dificuldades.

Citando Hyman, Leôncio nos dá idéias para as alternativas do sindicalismo, poderiam aos poucos se tornar sociedade de auxílio mútuo, agindo em coalização produtiva com as empresas, tornando-se um parceiro social com os governos ou tornar-se um movimento social. Ainda que nenhuma dessas soluções seja efetivamente boas o sindicalismo deveria optar por um desses modelos para sobreviver ${ }^{106}$.

\footnotetext{
${ }^{104}$ Destino do sindicalismo. Editora da Universidade de São Paulo: Fapesp, 2002, p.273.

105 Ibdem, p.275/276.

${ }^{106}$ Ibdem, p.285.
} 
Talvez estejamos falando de fato do declínio de um sindicalismo tal qual ele existiu, no Brasil podemos dizer que os sindicatos adquiriram autonomia, mas certamente o trabalhador ainda não conquistou sua real liberdade de organização e talvez isso nunca tenha de fato ocorrido em nenhum lugar do planeta. Talvez fosse melhor apostar em Hirst e Thompson (1998) ${ }^{107}$ quando falam da "governabilidade possível”, com políticas de nível nacional, contando com um equilíbrio, cooperação e competição entre as empresas e os principais interesses sociais.

A crise estaria então ligada muito mais com a orientação e a forma de atuação sindical. Os sindicatos devem ter de lidar com o "pluralismo societal” e a desarticulação do social. Iram Rodrigues nos questiona se "vale dizer, o que impediria a instituição sindical de se reestruturar e, até mesmo, se “reinventar” para poder continuar desempenhando importante papel nas relações entre capital e trabalho nas sociedades democráticas? ${ }^{108}$.

Certamente os sindicatos já estão conquistando saídas, resta saber se essas saídas poderão manter estas organizações como organizações de movimentos políticos e reivindicatórios ou as tornarão outra coisa. Essa “outra coisa” não necessariamente deve estar imbuída de negatividade, pelo contrário pode sempre de alguma forma representar um retorno positivo, quer dizer, aproveitar aquilo que dá certo, seja na forma sindical seja na forma do associativismo.

Defendemos a tese de que, uma vez aceito que há uma nova tendência nas relações de trabalho capital e que esta tendência modificou e vem modificando a forma do sindicalismo ser, seja por vias econômicas ou políticas, o sindicato pode e deve se relacionar com muitas outras questões do "mundo da vida".

No entanto, apesar de toda a discussão feita até o momento, é necessário destacar que o

107 Globalização em Questão. Petrópolis: Vozes, 1998. Caps. I e VIII. p.293.

108 Transformações do trabalho e ação sindical no final do século XX: algumas questões, 2001, p.165. 
futuro do sindicalismo no Brasil ainda é cercado de muitas incertezas. Recorremos mais uma vez às teses de Boito ${ }^{109}$ (2003), em sua análise a ascensão do governo Lula não correspondeu às expectativas da esquerda brasileira e internacional, uma vez que manteve os pilares do modelo capitalista neoliberal dependente, inclusive no que se refere à redução dos direitos sociais, na desregulamentação do mercado de trabalho e na desindexação dos salários. O apoio ao governo Lula vem ao menos de três frentes: da alta classe média, da população mais pobre assistida pelos programas sociais e por parcela do sindicalismo que nos interessa mais de perto.

A mudança de orientação do Partido dos Trabalhadores e dos integrantes da equipe de governo faz parte de um processo longo e profundo, inclusive contando com o apoio de fração da classe média superior. Fruto disso está nas relações contraditórias da alta classe média com os direitos sociais e com o Estado de bem-estar social. A alta classe média suporta então os custos da política neoliberal, inclusive das políticas compensatórias, para manter sua posição econômica e social, uma vez que para suas famílias, são garantidos os melhores postos de trabalho, condições de saúde e educação. Mas o apoio a esse modelo também tem base em setores da classe mais popular, de uma forma distorcida do conceito de hegemonia de Gramsci sintetizado nos Cadernos do Cárcere:

"Nessas passagens, a hegemonia é apresentada como adesão positiva e ativa das classes subalternas aos valores e idéias da classe dominante, adesão motivada por ganhos materiais reais obtidos pelos trabalhadores. Ora, de fato, não é isso que ocorre com a hegemonia neoliberal. Aqui não há ganhos efetivos para as classes populares e a adesão ao neoliberalismo pode se apresentar, não só como adesão positiva e ativa, mas também, dependendo do setor popular considerado, como adesão negativa, como ilusão ideológica ou como neutralização política” ${ }^{110}$.

Boito entende que o apoio sindical ao governo Lula está inserido em uma situação próxima ao modelo de "classe detentora do aparelho de Estado" formulado por Nicos

\footnotetext{
${ }^{109}$ A hegemonia neoliberal no governo Lula. Revista Crítica Marxista, n.17, Rio de Janeiro, Editora Revan, 2003.

${ }^{110}$ Ibdem , p.5.
} 
Poulantzas, os operários de renda mais remediada (metalúrgicos, bancários e petroleiros, ligados à Articulação Sindical, corrente hegemônica da CUT), estariam na base desse apoio construindo um novo sindicalismo operário. Ocupando altos cargos da burocracia pública, sem, no entanto ter influência decisiva na formulação de políticas econômicas. Este núcleo duro do novo sindicalismo acredita poder tirar vantagem do neoliberalismo mantendo o crescimento econômico e gerando empregos ${ }^{111}$.

Para entendermos essa postura desse novo sindicalismo, Boito recorre ao passado não muito distante quando a parcela mais qualificada dos sindicatos lutavam pela livre negociação salarial e por um estado de bem estar social no decorrer dos anos 70 e 80, para depois se transformar em um novo corporativismo sindical, saíram de uma posição de vanguarda social para um corporativismo estreito e fechado.

O Brasil vai na contramão da resolução $n^{\circ} 87$ da OIT que propõe a indevida tutela estatal colocando em questão o próprio sistema de corporativismo de Estado inaugurado com o MT de Getúlio Vargas de 1930, para Rodrigues, as modalidades de corporativismo resumem-se da seguinte forma:

“Geralmente, o conceito é entendido como uma forma de organização das classes sociais, ou das “forças produtoras”, através de uma ação reguladora do Estado, que busca integrar os grupos profissionais representativos do Capital e do Trabalho em organizações verticais e não conflitivas. No terceiro mundo estaria relacionado a elites “modernizantes” e não como resposta ao medo da insurreição do proletariado, êxito viria de sua capacidade de reduzir os conflitos sociais e de acomodar interesses num momento de declínio do poder oligárquico $^{112}$.

Na imprensa atual verificamos a intensificação do debate com a possibilidade do fim da contribuição sindical compulsória. Para Zylberstajn (2007) ${ }^{113}$ a contribuição deve ser

\footnotetext{
111 Ibdem, pág.6.

112 Pág.57, Destino do sindicalismo. Editora da Universidade de São Paulo: Fapesp, 2002.

113 Hélio Zylberstajn, Folha de São Paulo, sexta-feira 23 de Novembro de 2007, Tendências e Debates Contribuição sindical ou confusão sindical?
} 
obrigatória mesmo para os não associados, justifica que quando um sindicato consegue uma melhoria a conquista é estendida para todos os trabalhadores, sendo uma conquista de bem público. O problema maior reside no fato de saber quem cobra o que não necessariamente deveria ser O Estado: “a compulsoriedade é direito do sindicato, e não obrigação do Estado”. Há o problema dos sindicatos receberem receitas sem a exigência de contrapartida, a pergunta é: “Como conciliar a obrigatoriedade da contribuição com a prestação de serviços e a efetiva representatividade?... O Estado deixaria de garantir a coleta, só garantiria o direito do sindicato de cobrar. Ao sindicato caberia a responsabilidade pela cobrança, o esforço de recolher as contribuições dos trabalhadores, bem como a decisão de quanto e como repassar a receita para as entidades superiores. Tendo que cobrar diretamente dos trabalhadores, seria mais pressionado a prestar conta a eles”. O argumento se aplicaria igualmente às entidades patronais.

Outros problemas ainda muito complexos referem-se à fiscalização das contas dos sindicatos $^{114}$ e os problemas de acusações de corrupção, a verdade é que com o dinheiro que os sindicatos arrecadam seria muito melhor aplicado no desenvolvimento do trabalhador se fossem, pelo menos aqui no Brasil, mais transparentes e com uma mentalidade inovadora, isso certamente faria bem não apenas ao Turismo Social mas principalmente para a classe trabalhadora.

\footnotetext{
${ }^{114}$ Lucas Ferraz, 3 de Abril, de 2008 Folha de São Paulo, Lula atribui veto ao seu passado sindical, quintafeira,. Lula "explicou ontem que vetou o artigo que possibilitava fiscalização do TCU nas contas de sindicatos, confederações e federações por causa de seu passado no sindicato e alegou que a fiscalização poderia resultar em perseguição política” e com o fim da autonomia sindical!”.

Para os sindicalistas caberia ao MP averiguar eventuais desvios, advogados dizem que deve ser tarefa do TCU. A polêmica é grande, procurador do TCU, Marinus Mariscu, crítica o veto do presidente, "um retrocesso", professor da PUC-SP, Pedro Serrano diz que "deve ser papel do TCU fiscalizar a aplicação de qualquer verba pública, em especial em entidades que são privadas, mas tem caráter comunitário”, complementa "qualquer contribuição compulsória do dinheiro das pessoas ao governo é dinheiro público. Seria diferente se fosse pagamento voluntário". Professor do Mackenzie de direito constitucional João A. Wiegerinck entende que as centrais tem de prestar contas.

Já o advogado da UnB Marthius S. Lobato afirma que quem vai fiscalizar é o próprio trabalhador, respeitando assim a constituição de 1988 que impede a intervenção e interferência das entidades sindicais.
} 


\section{PLANEJAMENTO URBANO COM VISTAS AO TURISMO - O CASO DO MUNICÍPIO DE PRAIA GRANDE.}

A distribuição, a história e a própria forma de "ser" das colônias de sindicato está absolutamente ligada à história dos trabalhadores do Brasil e do Estado de São Paulo o mais industrializado do país. Em geral as colônias de sindicatos são extensões dos próprios sindicatos e expressam uma territorialidade, concentrando-se no litoral paulista a maior expressão desse fenômeno no mundo, são cerca de 160 colônias, representando os diversos sindicatos da Grande São Paulo e de outras importantes regiões metropolitanas como as de Campinas e da própria Baixada Santista ${ }^{115}$. Geram impactos na gestão do território, são alvos de políticas públicas, ainda que nunca muito claras. São mantidas pelas contribuições sindicais, pelas taxas de uso e manutenção, mas também estão abertas ao público comum, isto é, não sindicalizado ou associado, pagando evidentemente taxas maiores e sempre como segunda opção nas reservas. Enfim, são populares e geram empregos sendo fundamentais para a economia urbana dos municípios ligados ao turismo.

De acordo com Gonçalves, As discussões acerca do lazer no meio operário da Grande

\footnotetext{
${ }^{115}$ Anexo 2.
} 
São Paulo se fundamentam em algumas mudanças ocorridas no Brasil originadas com o golpe militar de 1964, momento em que se deram profundas transformações no campo político, social, educacional e, principalmente, econômico. Foi sob a chancela dos generais ditadores que ocorreu grande abertura ao capital internacional, favorecendo nomeadamente a instalação de indústrias multinacionais no território brasileiro, com o objetivo de dinamizar as relações entre capital e trabalho, possibilitando o chamado "milagre econômico brasileiro".

É nesse período que a maior parte das colônias de férias dos sindicatos e federações originaram-se, a partir da doação de terrenos no litoral paulista (especialmente em Praia Grande e Caraguatatuba) às entidades sindicais, pelo então governador de São Paulo, Carvalho Pinto, na década de sessenta. Apesar de Vargas dar o impulso inicial ao lazer promovido pelos sindicatos, somente com uma intervenção de porte como a feita pelo governo militar, é que temos um "boom” das colônias.

Como um dos objetivos do trabalho é buscar uma melhor compreensão dos impactos das colônias no planejamento urbano, compreendemos ser importante fazermos uma análise do município visitado, a Praia Grande.

Praia Grande é um município que atualmente situa-se entre as chamadas cidades médias, com mais de duzentos mil habitantes (239.918, SEADE, 2005) e uma taxa de crescimento da população de mais de 3,71\%, acima da média nacional. Com uma população flutuante de 300.000 nos finais de semana a 1.500 .000 na alta temporada de verão. Como podemos observar nas tabelas abaixo, é crescente a demanda por serviços públicos como a coleta de lixo, o que certamente exige grande dedicação da parte dos planejadores urbanos, tanto pelo crescimento populacional como pela população flutuante.

Evolução da coleta de lixo séptico em toneladas:

$\begin{array}{cr}\text { Ano } & - \\ 1994 & \text { toneladas } \\ 1995 & 81,66 \\ 1996 & 81,05 \\ & 89,99\end{array}$




$\begin{array}{cl}1997 & 96,80 \\ 1998 & 124,66 \\ 1999 & 134,11 \\ 2000 & 146,22 \\ 2001 & 152,71 \\ 2002 & 172,91 \\ 2003 & 166,43 \\ 2004 & 186,84\end{array}$

Evolução da coleta de lixo domiciliar em toneladas:

$\begin{array}{lllc}\text { Ano } & \text { janeiro } & \text { junho } & \text { total } \\ 1994 & 5.486 & 1.980 & 31.653 \\ 1995 & 7.249 & 2.835 & 46.024 \\ 1996 & 8.769 & 3.254 & 53.304 \\ 1997 & 8.927 & 3.475 & 58.236 \\ 1998 & 9.136 & 3.792 & 60.021 \\ 1999 & 9.108 & 4.093 & 61.781 \\ 2000 & 9.189 & 4.023 & 61.307 \\ 2001 & 9.608 & 4.566 & 61.873 \\ 2002 & 8.750 & 4.556 & 60.152 \\ 2003 & 8.484 & 3.720 & 56.406 \\ 2004 & 8.458 & 3.847 & 58.821\end{array}$

Fonte: Secretaria de Serviços Urbanos (2005), Central Integrada de dados e estatística prefeitura da Estância Balneária de Praia Grande.

Outros dados referem-se ao número de trabalhadores formais por sexo, escolaridade, rendimento, por setor de atividade econômica, por ocupação com maior número de trabalhadores formais e movimentação do emprego formal.

O que pode ser avaliado é que a maior faixa etária de trabalhadores concentra-se entre os 18 até 39 anos de idade, a maior parte desses trabalhadores tem no máximo até o ensino fundamental completo e a renda média varia entre 2 e 7 salários mínimos. O setor de serviços é o que mais gera empregos, seguido pelo comércio e pela administração pública. A movimentação do emprego parece ser bastante elevada em virtude da sazonalidade, são certamente empregos temporários. O setor de comércio e de serviços são os exemplos mais claros, praticamente o mesmo número de admitidos corresponde ao número dos desligados.

O município conta com boa parcela do território protegida, são cerca de $30 \%$ do território distribuído em três áreas de proteção legais por Unidade de Conservação e ligadas ao Ecossistema Mata Atlântica (mangue e restinga) (ver mapas de localização anexo 5 p.112 e zoneamento do município p.120) 
Parque Estadual Xixová/Japuí, 5,54 km2, 2,10\% da área do município.

Parque Estadual Serra do mar, 45,31 km2, 31,25\%da área do município.

Piaçabu, 8,54 km2, 5,9\% da área do município.

A história de Praia Grande está ligada à história do município de São Vicente, vila fundada em 1532. A emancipação política de Praia Grande tornou-se realidade apenas em 1967, quando foi nomeado o engenheiro Nicolau Paal como interventor federal, antes disso, sem autonomia política para solucionar seus problemas, todas as decisões dependiam da Prefeitura de São Vicente. De acordo com Siqueira (2002): “A emancipação política não aconteceu de repente, nem foi vontade de uma pessoa só. As pessoas que aqui moravam não estavam contentes com os problemas que enfrentavam, como a falta de saneamento, escolas, transportes, hospitais, abastecimento de água, luz, vias de acesso. Por isso, os moradores do bairro de Solemar viram a possibilidade de se desmembrar de São Vicente e de Praia Grande ganhar autonomia”"

O povoamento definitivo do município iniciou-se no começo do século XX com a construção da Fortaleza Militar de Itaipú, mas o povoamento regular iniciou-se apenas por volta de 1930 quando aparecem os primeiros veranistas em busca de descanso e a partir de então inicia-se uma corrida imobiliária.

Até o início do século XX, a principal forma de ligação de Praia grande com São Vicente era feita entre os portos Do Campo e do Tumiarú, a construção da Ponte Pênsil em 1914 fez parte das intervenções urbanística propostas pela Comissão de Saneamento, chefiada pelo engenheiro Saturnino de Brito. Além da ligação, havia a finalidade de conduzir os esgotos de Santos para desaguar no forte de Itaipu, divisa entre São Vicente e Praia Grande. A obra proporcionou benefícios e malefícios: “Com a Ponte Pênsil, por onde começaram a trafegar carros, carroças e pessoas, a Praia Grande passou a estar ligada a São Vicente. Isto era uma coisa boa para os moradores da época. Mas, infelizmente, o esgoto que chegava em nossa cidade para desaguar no mar poluía as nossas praias”"117.

\footnotetext{
${ }^{116}$ Paisagens da memória: história de Praia Grande. Prefeitura da estância balneária de Praia Grande, p.11.

${ }^{117}$ Ibem, p.69.
} 
De acordo com Ueno (2004), Praia Grande “Como bairro periférico de São Vicente sofrendo com os diversos problemas sociais e insatisfeitos com a total falta de atenção da prefeitura vicentina, a população de Praia Grande sente a necessidade de autonomia político-administrativa”, havia um total descaso para com a infra-estrutura básica ${ }^{118}$. A disputa política dos moradores com São Vicente pela emancipação durou de 1953 até 1967 quando então finalmente é conquistada a emancipação político-administrativa.

Por conta do acesso pela ponte houve uma rápida valorização e conseqüente especulação imobiliária a atração turística passou a ser então a principal fonte de renda da localidade. Inicialmente um turismo com fins terapêuticos, mas com as transformações ocorridas a partir da década de 60 a cidade passou a receber o turista de um dia, sem, no entanto o município contar com infra-estrutura adequada para suportar a demanda.

Para Siqueira é a partir da administração municipal de 1993 que foi elaborado um projeto para reurbanizar a orla e incentivar o turismo, o comércio e novas construções de casas e edifícios. As reformas passavam a valorizar a cidade e a criar uma identidade com os moradores $^{119}$.

Em 1970 viviam no município 19 mil pessoas, atualmente já são mais de 240 mil. O município que, mesmo contando atualmente com dois emissários submarinos, apresenta praias com os piores índices de balneabilidade. O problema é antigo e persiste, Midaglia (2001), em levantamentos de balneabilidade do litoral paulista indicava que a maior parte das praias do município enquadrava-se nas classes D e E (respectivamente praias com queda acentuada de balneabilidade e praias com balneabilidade sempre ruins). O município já foi bastante esteriotipado como a "praia dos farofeiros” mas é evidente que a lentidão no processo de emancipação dificultou a boa gestão do território ${ }^{120}$. Quanto a questão da emissão dos esgotos, Praia Grande é o município da região com maior orla para mais de 233 mil habitantes, São Vicente, pelo contrário é um dos municípios litorâneos com menor

\footnotetext{
${ }^{118}$ Pequena História de Praia Grande, UNIFAI, p.4.

${ }^{119}$ Paisagens da memória: história de Praia Grande. Prefeitura da estância balneária de Praia Grande, p.76

120 Turismo e meio ambiente no litoral paulista: dinâmica da balneabilidade nas praias in Turismo: Impactos sócio-ambientais, org.: Lemos, Amália I. G. de. São Paulo: Hucitec, p.54.
} 
orla e com mais de 333 mil habitantes (IBGE, 2007).

Relembrando, é em Praia Grande que se encontra a maior concentração de colônias de férias da América Latina, particularmente na Avenida dos Sindicatos concentram-se cerca de $80 \%$ das colônias do município. A gestão municipal dos últimos anos tem procurado desenvolver uma reurbanização e dentre os projetos há o de transformar as colônias em um grande complexo hoteleiro (Sítio da Prefeitura Municipal de Praia Grande, 23 de Agosto de 2005). O complexo abrigaria grandes eventos que ocorram na baixada santista e que exigem uma quantidade de leitos normalmente não disponíveis nos outros municípios da região. De acordo com a prefeitura os cerca de 7 mil leitos ficam disponíveis a maior parte do ano havendo então a possibilidade de receber grandes eventos gerando importantes recursos financeiros para o município e sindicatos e federações, donos dos estabelecimentos, sem no entanto comprometer o lazer dos associados. O tema a respeito do suposto "complexo hoteleiro" é bastante polêmico e até o momento na verdade uma ficção (ver anexos 6 e 7, p. 113 a 119).

Certamente é uma idéia que mobiliza o interesse de políticos, líderes sindicais e logicamente de empresários, mas não fica claro o posicionamento do associado e mesmo de alguns líderes sindicais. Outras propostas de uso das colônias em épocas de baixa temporada já haviam sido feitas pela prefeitura, o receio é de que a idéia seja ampliada para os momentos de alta temporada, comprometendo dessa forma o interesse maior das colônias: as férias do trabalhador associado.

Parece-nos um claro exemplo da atuação da lógica do capital influindo na dinâmica territorial do lugar. Questões importantes temos de responder como: Por que a Praia Grande foi o município escolhido para abrigar a maior concentração de colônias de férias da América Latina? Talvez a resposta aparece ao tentarmos solucionar outra questão: Por que as colônias não foram criadas em outros municípios da baixada santista? A discussão deve envolver ao que chamamos tradicionalmente de fatores geográficos, sociais, econômicos, históricos e certamente políticos. 
Como Milton Santos nos mostra em A Urbanização Brasileira (1998, p.96), as cidades médias desenvolveram-se adotando modelos geográficos semelhantes aos das grandes metrópoles com aumento do desemprego e do sub emprego e inclusive na forma da gestão, “O capitalismo monopolista agrava a diferenciação quanto à dotação de recursos, uma vez que parcelas cada vez maiores da receita pública se dirigem à cidade econômica em detrimento da cidade social".

Já há alguns anos algumas colônias passaram a ser terceirizadas, os novos gestores confrontam-se com as antigas formas de gestão de outras colônias ainda comandadas diretamente pelos próprios líderes sindicais. Como não poderia deixar de ser, as empresas de terceirização possuem uma outra visão que não mais aquela de que as colônias foram criadas sem o intuito de darem lucro, inclusive buscando a formação de uma associação das colônias de Praia Grande. Alguns sindicatos buscam estratégias como a parceria com o governo local em fazer permutas com o governo de Buenos Aires buscando atrair mais turistas nos meses de alta temporada.

Mas na verdade há muito por se fazer. Sobre tornar as colônias menos deficitárias é necessária a gestão integrada dos sindicatos, trabalhando em conjunto segundo os conceitos mais avançados de sistemas em rede inclusive envolvendo material de divulgação, mas para isso funcionar gestores e lideranças sindicais precisam de uma integração ampla que começa a sr pensada.

Praia Grande já possui seu plano Diretor aprovado desde 1996, destacamos o item III, do desenvolvimento econômico que em seu artigo $10^{\circ}$, trata de "apoiar e fomentar as iniciativas de diversificação, especialização e qualificação das atividades voltadas ao turismo/lazer, bem como a formação da mão de obra local com vistas a confirmar e potencializar a vocação turística do Município;”de “estimular e fomentar preferencialmente a organização de pequenas empresas não poluentes e de baixa relação Capital / Trabalho, voltadas à produção de bens de consumo dirigido ao mercado turístico, visando à ampliação do emprego e à coexistência da atividade industrial com o turismo e lazer;" e "estabelecer convênios com o SENAI, SENAC e outros estabelecimentos de ensino, visando à 
instalação de unidades de ensino profissionalizante, especialmente de escola de hotelaria e turismo de âmbito regional;",

Há também a disposição sobre o Plano Diretor de Turismo, ainda em faze de elaboração. O governo municipal, portanto faz jus às suas atribuições de elaborar os planos, falta por outro lado a participação efetiva dos diversos atores sociais. Nas entrevistas realizadas as lideranças sindicais não demonstraram grande envolvimento com a implementação das diretrizes e pouco participam do Conselho Municipal. Ora, justamente na Avenida dos Sindicatos é que se faz necessário uma orquestração das diversas esferas governamentais junto com os novos gestores e as lideranças sindicais para uma ampla reurbanização, dando melhor qualidade à paisagem da cidade e à sua própria identidade. Podem inclusive elaborar visitações turística pré-programadas aos monumentos da cidade como por exemplo a Fortaleza Militar de Itaipu de 1901 ainda em atividade, o Pórtico da viação de 1927 e o Conjunto Arquitetônico Ocian de 1926. Outra possibilidade refere-se à organização de passeios para as Unidades de Conservação, obviamente respeitando a lei de Zoneamento Ecológico Econômico ${ }^{122}$.

Com relação às políticas públicas voltadas para o turismo, é de pretensão do governo federal via Ministério do Turismo de investir no turismo interno "por meio de vigorosos investimentos em programas de turismo social”, dirigidos a aposentados, trabalhadores e jovens, nos períodos de baixa ocupação. O programa Viaja Mais - Melhor Idade cuja idéia é a de se aproximar de experiências como na França (Cheque Vacance), na Espanha e no Chile (Vocaciones Tercera Edad), aumentando o número de empregos, incrementando a ocupação na baixa temporada, melhorando a infra-estrutura turística e melhorando a qualidade de vida. Objetivando uma mudança cultural no brasileiro que ainda viaja pouco com preços acessíveis voltados para um produto nobre.

Os pacotes "variam de três a oito dias, a preços promocionais e contam com a facilidade de crédito consignado para aposentados e pensionistas do INSS, com juros abaixo de $1 \%$ ao

\footnotetext{
${ }^{121}$ Lei complementar n 152, de 26 de dezembro de 1996 “Aprova o Plano Diretor da Estância Balneária de Praia Grade para o período de 1997 a2006.

${ }^{122}$ Em anexo 3.
} 
mês” e recursos advindos do Fundo de Amparo do Trabalhador (FAT), com metas de implantação progressiva em todas as unidades da federação, visando a ocupação da rede hoteleira em geral, inclusive das colônias de férias ${ }^{123}$.

Como conceito a idéia é sem dúvida excelente, no entanto a precocidade do projeto não nos permitiu uma avaliação, mas, devemos de qualquer forma, fazermos algumas observações: m primeiro lugar a proposta de juros consignados poderia ser substituída por uma poupança de maior rentabilidade voltada para o segmento, em segundo lugar acreditamos que o governo deveria voltar melhor atenção às próprias instituições que já se ocupam da atividade, no caso as associações e sindicatos e terceiro e mais importante, o projeto não apresentou de fato um estudo profundo para o caso que envolvesse verdadeiras estratégias de implementação e de divulgação, de qualquer forma é um princípio e que merecerá atenção sobre seus resultados em um futuro próximo.

Para o futuro é preciso apreender com os erros do passado, a concentração das colônias sem uma mínima padronização seja pensando em termos arquitetônicos e paisagísticos, mas, sobretudo ambientais continuará a causar problemas como os que já ocorrem em Praia Grande como a superlotação nos finais de semana. Por outro lado ao pensar em políticas públicas para o setor é evidente que existem soluções bastante exitosas como são os casos do SESC e da AFPESP, e na verdade mesmo os sindicatos já possuem algo bastante interessante em suas mãos, bastam, como princípio, se imaginarem instituições mais modernas segundo as necessidades dos novos tempos.

\footnotetext{
${ }^{123}$ in: Folha de São Paulo, terça-feira, 4 de Setembro de 2007, Tendências e Debates, "Fazer a roda girar”, Marta Suplicy.
} 


\section{CONCLUSÃO}

De forma sintética procuramos na conclusão recuperarmos as idéias pretendidas como objetivos.

Com relação ao planejamento urbano com vistas o turismo social e no que concerne à proteção do meio ambiente e da paisagem acreditamos ter demonstrado que há de fato boas soluções para o setor. As colônias do SESC-Bertioga e da AFPESP são a grande referência, inclusive, na nossa visão, suas colônias podem mesmo ser consideradas patrimônios dos municípios em que se encontram. Até porque se preocupam em seguir normas e 
regulamentações previstas em planos diretores, de Unidades de Conservação e Áreas de Proteção Ambiental.

Apesar dos sindicatos serem indicados para contribuir no processo de democratização do turismo, inclusive porque sempre estiveram inseridos no processo. Já as associações voltadas para o setor são instituições muito mais modernas correspondendo com uma gestão e qualidade de hospedaria superior. Além disso, investem em um turismo com atividades culturais para um turismo mais ativo. Mas é também uma questão de os sindicatos se interessarem em apreender com as associações.

Os sindicatos devem decidir qual modelo querem seguir como instituição, se do tipo “movimento social”, “assisencialista” ou "sindicato cidadão” e principalmente se ficará atrelado ao governo da forma que ainda é ligado à contribuição compulsória. Tornando-se instituições mais modernas e transparentes os sindicatos continuarão sempre a serem organizações fundamentais à sociedade, inclusive podendo prestar um serviço de turismo com grande qualidade ao trabalhador de baixa renda.

Sobre subsídios e subvenções, as associações e ou sindicatos bem organizados e estruturados podem mesmo chegar a dispensar a ajuda governamental, podem inclusive adquirir seus imóveis com os próprios recursos, esse é o caso da colônia da Ordem dos Advogados do Brasil (OAB) que inaugurou um empreendimento junto ao rio Paraná, mas como também expomos sobre algumas colônias da AFPESP construídas totalmente com recursos próprios.

Gostaríamos talvez em trabalho futuro analisar de forma mais profunda o comportamento do tipo de turista que freqüenta as colônias, na verdade entendemos que há um exagero na busca do destino "sol e praia”, o trabalhador poderia ser orientado a buscar outros destinos, de forma que encontrasse maior qualidade em sua viagem e estadia. Outro ponto que gostaríamos de dedicar melhor pesquisa é com relação à geração de empregos e sua sazonalidade. 
Sobre a formulação de possíveis políticas públicas para o setor, seria interessante formular uma padronização para as colônias, seja no âmbito da gestão e hospedaria como na ocupação do território. Seria a base para o governo quando fosse pensar em subsídios e subvenções, inclusive para o transporte para aqueles realmente mais necessitados. Também o governo deve facilitar e ou incentivar associações e sindicatos que desenvolvam programas voltados para o Turismo Social e colônias de férias.

Sobre as classes menos favorecidas, essas de fato ainda necessitam de muitos subsídios, pois não conseguem de fato realizar, por seus próprios meios, uma viagem com “custos normais”, portanto são grande alvo para políticas do tipo “o interior vai a praia”, cujos subsídios são totais.

Infelizmente talvez Lafargue ficasse surpreso ao saber que em pleno século XXI a sociedade contemporânea na maioria das nações ainda mal usufruem bem do lazer e quanto mais do turismo com qualidade. Como no passado, as dificuldades das classes baixas e da nossa espremida classe média em obter lazer continuam as mesmas: falta de tempo, falta de reais oportunidades e obviamente falta de dinheiro. E sua sentença em grande medida ainda continua verdadeira: “O homem veio ao mundo para sofrer e não para gozar”124.

De qualquer forma, acreditamos que o trabalho contribua com conhecimentos sobre turismo, que apóiem as decisões governamentais e das instituições envolvidas em seus diferentes setores de atuação ou desperte ao menos algum interesse por outros estudos.

\footnotetext{
${ }^{124}$ LAFARGUE, Paul. O direito à preguiça e outros textos. Ed. Estampa, Lisboa, 1977.
} 


\section{BIBLIOGRAFIA CONSULTADA}

ALMEIDA, Marcelo Vilela. Turismo Social: Por uma compreensão mais adequada deste fenômeno e sua implicação prática na realidade brasileira. USP- ECA, dissertação de mestrado. Relações Públicas, Propaganda e Turismo. São Paulo 2001.

ANDRADE, José Vicente de. Turismo, fundamentos e dimensões. Ed. Ática, São Paulo, 1998. 
BAPTISTELA, Humberto. Formulação de um programa de marketing de turismo social para o trabalhador. Tese de doutorado, FEA - USP, São Paulo, 1982.

BENI, Mário Carlos. Análise Estrutural do Turismo. Ed. Senac, São Paulo, 2004.

BEYNON, Huw - O sindicalismo tem futuro no século XXI?, in: Além da Fábrica, Editorial Boitempo, 2003, São Paulo.

BITS. Bureau Internacional de Turismo Social. htpp://www.bits-int.org

BOITO Júnior, Armando - O sindicalismo de Estado no Brasil: uma análise crítica da estrutura sindical. Campinas, SP: Editora da UNICAMP; São Paulo: HUCITEC,1991. _ A crise do sindicalismo, in: Além da Fábrica, Boitempo Editorial, 2003, São Paulo.

Fichamento: BOITO, Armando Jr..A hegemonia neoliberal no governo Lula. Revista Crítica Marxista, n.17, Rio de Janeiro, Editora Revan, 2003.

BOLOGNANI, G. B. Qual o segredo para o crescimento da AFPESP? Folha do Servidor Público, Órgão oficial da Associação dos Funcionários Públicos do Estado de São Paulo, Maio de 2006 n.162.

BOSCHI R. Renato e Diniz Eli. O Corporativismo na Construção do Espaço Público, in Corporativismo e Desigualdade. IUPERJ, Rio Fundo Ed, 1991.

CASTELLS, Manuel - A sociedade em rede. Vol. I, São Paulo, Paz e Terra, 1999.

CASTRO, Nair Apparecida Ribeiro de. O lugar do turismo na ciência geográfica: Contribuições teórico-metodológicas à ação educativa. Tese de doutorado, FFLCH, USP, Depto. De Geografia, São Paulo, 2006. 
DENCKER, Ada de Freitas Maneti. Métodos e técnicas de pesquisa em turismo. São Paulo ed. Futura 1998.

DUMAZEDIER, Joffre. Lazer e Cultura Popular. Série Debates, Ed. Perspectiva, São Paulo, 2001.

DURAND, Afonso L. E MOREIRA A. C.. História dos 66 anos da Fundação da AFPESP. Ed. São Paulo Shimbun, São Paulo, 1998.

Folha do Servidor Público, janeiro de 2005 a abril de 2007. Associação dos Funcionários Públicos do estado de São Paulo (AFPESP)

Federação dos Trabalhadores nas Indústrias Químicas e farmacêuticas do Estado de São Paulo, Departamento de Saúde - Projeto “Verão sem AIDS e Drogas”, 2004.

Jornal da federação - Federação dos Trabalhadores nas Indústrias Químicas e Farmacêuticas do Estado de São Paulo. Jornalista responsável: Paulo de Tarso Pires Gracia. Números 79 ao 87, de março de 2005 a março de 2006.

GOMES, Ângela de Castro. República, Trabalho e Cidadania. in Corporativismo e Desigualdade. IUPERJ, Rio Fundo Ed, 1991.

GOMES, Paulo César da Costa. Geografia e Modernidade. Ed. Bertrand Brasil, Rio de Janeiro, 2003.

GONÇALVES JUNIOR, Luiz. Lazer no período da ditadura militar: o desvelar de depoimentos de sindicalistas da Grande São Paulo - Brasil. Revista Corpoconsciência, Santo André, n. 10, p.35-55, 2o sem., 2002. (ISSN 1517-6096).

HARVEY, David - A condição pós-moderna. São Paulo: Loyola, 1992. Parte II.

HIRST,Paul e THOMPSON, Grahame. Globalização em Questão. Petrópolis: Vozes, 1998. 
Caps. I e VIII.

IBGE - Roteiro Metodológico para Elaboração de Plano de Manejo para Reservas Particulares do Patrimônio Natural. Edição: Instituto Brasileiro do Meio Ambiente e dos

Recursos Naturais Renováveis Diretoria de Gestão Estratégica, Centro Nacional de Informação, Tecnologias Ambientais e Editoração, Brasília, 2004.

JOHNON, Allan G. Dicionário de sociologia: Guia prático de linguagem sociológica. Rio de Janeiro, Ed. Jorge Zahar, 1997.

LAFARGUE, Paul. O direito à preguiça e outros textos. Ed. Estampa, Lisboa, 1977.

MELLO, Neli Aparecida. Contradições territoriais, signos do modelo aplicado na Amazônia. In Meio Ambiente, Desenvolvimento e Sociedade. Sociedade e Estado/Departamento de Sociologia da Universidade de Brasília, 1986.

MIDAGLIA, Carmen L. Vergueiro. Turismo e meio ambiente no litoral paulista: dinâmica da balneabilidade nas praias in Turismo: Impactos sócio-ambientais, org.: Lemos, Amália I. G. de. São Paulo: Hucitec, 2001.

NAISBITT, John - Paradoxo Global. 1. O Paradoxo Global (1 a 52), 3. Turismo: A Globalização da Maior Indústria Mundial (115 a 168). Rio de Janeiro; Campus; São Paulo: Publifolha, 1999.

NUNES, Rizzato - Manual da Monografia, como se faz uma monografia uma dissertação uma tese. Ed. Saraiva, 2003.

PINHO, Diva Benevides. Dicionário de cooperativismo. Secção Gráfica da Faculdade de Filosofia, Ciências e Letras da Universidade de São Paulo, 1962. 
RAMALHO, José Ricardo e SANTANA, Marco Aurélio - Trabalhadores, sindicatos e a nova questão social, in: Além da Fábrica, Editorial Boitempo, 2003, São Paulo.

RODRIGUES, Leôncio Martins - Destino do sindicalismo. Editora da Universidade de São Paulo: Fapesp, 2002.

_ O sindicalismo corporativo no Brasil, in Partidos e sindicatos. Escritos de sociologia política, Editora Ática, 1990.

RODRIGUES, Iram Jácome - Transformações do trabalho e ação sindical no final do século XX: algumas questões.

SENNET, Richard. A corrosão do caráter, conseqüências pessoais do trabalho no novo capitalismo. Ed. Record, Rio de Janeiro, São Paulo, 2005.

SANTOS, Milton. A Urbanização Brasileira. Ed. Hucitec, São Paulo, 1998.

SIQUEIRA, Fátima Valéria. Paisagens da memória: história de Praia Grande. Prefeitura da estância balneária de Praia Grande, 2002.

SILVA, Sylvio Bandeira de Mello e. Turismo como desenvolvimento e redução da pobreza: uma perspectiva territorial. In Turismo comunitário e responsabilidade socioambiental. Org. Coriolano, Luzia M. N. Teixeira, Edulce, Fortaleza, 2003.

SESC (Serviço Social do Comércio)

_ Trajetória de Sucesso - turismo social/sesc. Serviço Social do Comércio / Departamento Nacional,2004.

_ Guia SESC Brasil 2004

_ Turismo Social no SESC SP. Turismo para Todos. 2006-04-26 
SILVEIRA, Maria Laura. Por um conteúdo de reflexão epistemológica em geografia, in Paisagem Território Região. Edunioeste, 2000.

_ Continente em Chamas, globalização e território na América Latina, organização e introdução. Ed. Civilização Brasileira, Rio de Janeiro, 2005.

SILVEIRA, Marcos A. T. da. - Turismo, políticas de ordenamento territorial e desenvolvimento. Um foco no estado do Paraná no contexto regional. Tese de Doutorado em Geografia, FFLCH, USP, São Paulo 2002.

SOUZA, Davisson C. C. de - Sindicato dos Metalúrgicos de Campinas e Região diante do desemprego no período de 1990 a 2002. Dissertação de Mestrado do depto. de Sociologia da FFLCH da Universidade de São Paulo, 2005.

UENO. Pequena história do município de Praia Grande. Trabalho de conclusão do curso em história. Centro Universitário Assunção, São Paulo UNIFAI, 2004.

ULIANA, Doval de Assis. Quadro comparativo: Associação e Cooperativas, consultoria para o SEBRAE.

YÁZIGI, Eduardo A.. A alma do lugar: turismo, planejamento e cotidiano em litorais e montanhas. - São Paulo : Contexto, 2001.

- Por uma política de turismo social, in, Lage, Beatriz H. (Org.). Turismo, hotelaria e lazer, ed. São Paulo: Atlas, 2004, v. um, p.31-69.

\section{ANEXOS}

1 - Transcrito de YÁZIGI, Eduardo A. Por uma Política de Turismo Social, págs. 60 e 61 2004:

“Considero os seguintes pontos os mais relevantes em benefício do turismo social, a ser irradiado a partir do Estado Nacional: 
1. promover uma política de transportes que inclua diferenciação de tarifas nas concessões e subvenções para transporte rodoviário e aeronáutico;

2. iniciar um vaso programa de navegação de cabotagem mista (passageiros e carga), marítima e fluvial, beneficiando o sonho ambientalista de aproveitamento da biomassa e da energia limpa;

3. criar um fundo nacional para financiamento de colônia de férias, em sistema de parceria ou outro que viabilize a multiplicação deste tipo de hospedagem;

4. estimular a incorporação da dimensão turística Juno à indústria e ao comércio, facilitando associações específicas da matéria, mediante algum tipo de benefício fiscal;

5. iniciar políticas de intercâmbio com países vizinhos, servindo-se do Ministério das Relações Exteriores e das Câmaras Brasileiras de Comércio no Exterior;

6. criar projetos-pilotos que atendam a vários tipos de experiências.

Da parte dos Estados, parece-me muito justo:

1. desdobrar as pertinências federais no que couber;

2. estimular a criação de comissões de planejamento turístico social, como uma das divisões de conselhos regionais de planejamento (que deveriam existir com ou sem turismo);

3. facilitar a captação de financiamentos.

Falando da esfera municipal, onde o turismo se realiza, conviria:

1. convocar e articular as representações comerciais, industriais, sindicais e todas as demais necessárias, a fim de definir e implementar um programa mínimo de hospedagem;

2. ceder, ou facilitar, a aquisição de uma gleba compatível com um bom projeto de colônia de férias. Em outros casos, deve-se pensar na isenção temporária ou definitiva de alguns impostos municipais;

3. difundir a predisposição de negociar a instalação de uma colônia de férias;

4. convocar e praticar a coordenação inicial a munícipes predispostos a integrar um banco de oferta de hospedagem.

Finalmente, a iniciativa privada, na figura das associações, deveria:

1. estudar possibilidades de consórcio para a construção de colônias;

2. não burocratizar a organização de colônias nem inchar sua organização, racionalizando os custos;

3. promover cursos de treinamento: cidadãos receptivos e tudo o mais que couber nas opções locais;

4. organizar operadoras turísticas próprias.” 
2 - Distribuição das colônias de férias do Estado de São Paulo por municípios

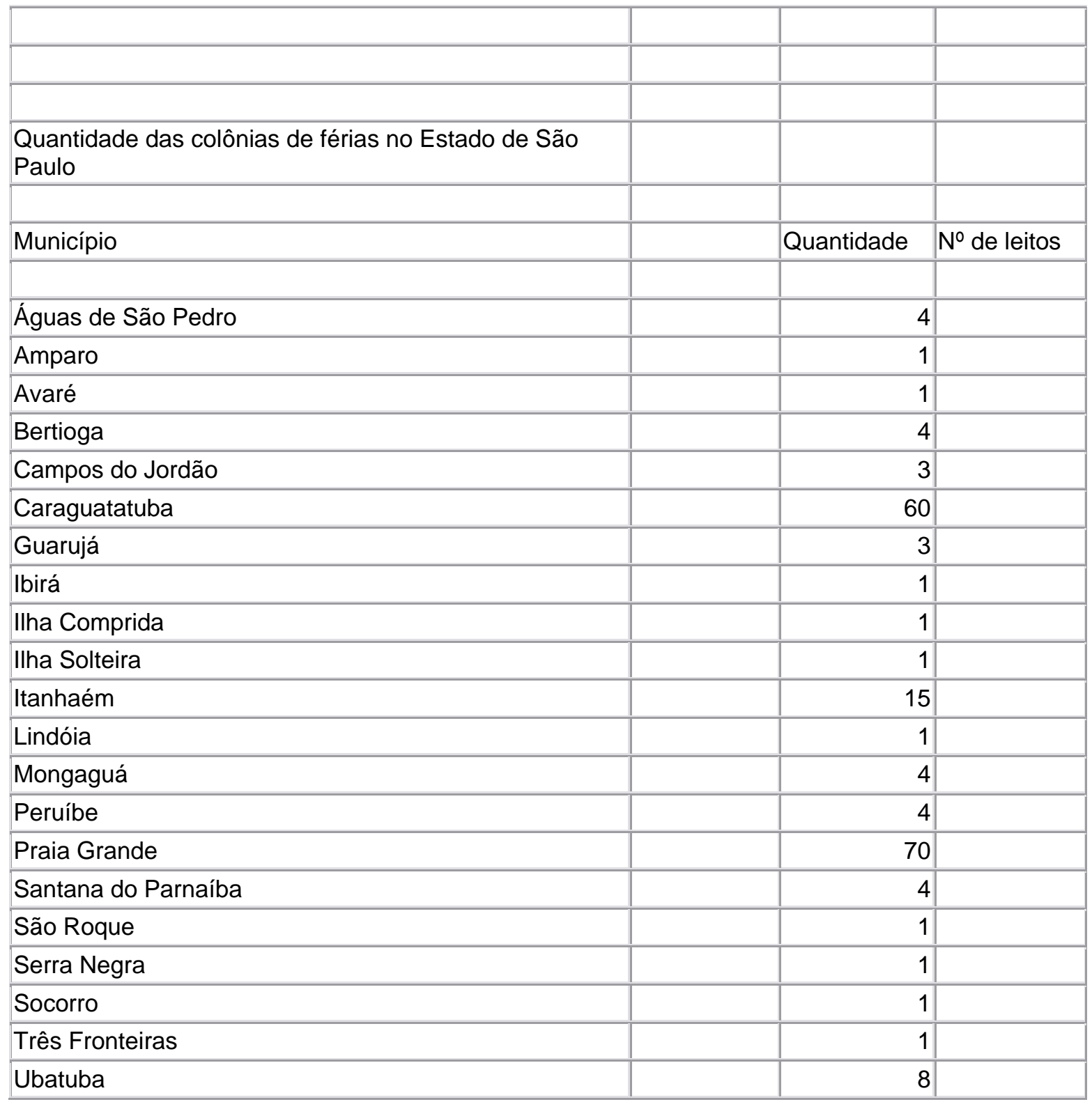

\section{3 - Zoneamento Ecológico Econômico}

São 38 compartimentos ambientais, delimitados por microbacias hidrográficas que podem possuir até cinco áreas de zoneamento ecológico-econômico, a seguir, de forma bastante resumida, considerando os usos permitidos de forma cumulativa, da zona 1 à zona 5: 
Zona 1: mantém os ecossistemas primitivos em pleno equilíbrio ambiental. Usos de preservação e conservação, pesquisa científica, educação ambiental, manejo auto-sustentado, ecoturismo, pesca artesanal, ocupação humana compatível.

Zona 2: com alterações na organização funcional dos ecossistemas primitivos, mas com capacidade de manter o equilíbrio mesmo com atividades humanas de baixo impacto. Usos permitidos para manejo sustentado, aquacultura, mineração baseada em plano diretor.

Zona 3: ecossistemas parcialmente modificados com dificuldade de regeneração natural. Usos permitidos para agropecuária, silvicultura e pesca industrial.

Zona 4: ecossistemas modificados, necessitando intervenções para sua regeneração parcial. Usos: assentamentos urbanos descontínuos restritos às unidades que o permitam, de acordo com o regulamento.

Zona 5: área bastante degradada. Usos: assentamento urbano consolidado, indústrias, terminais rodoportuários. 


\section{Anexo 4}

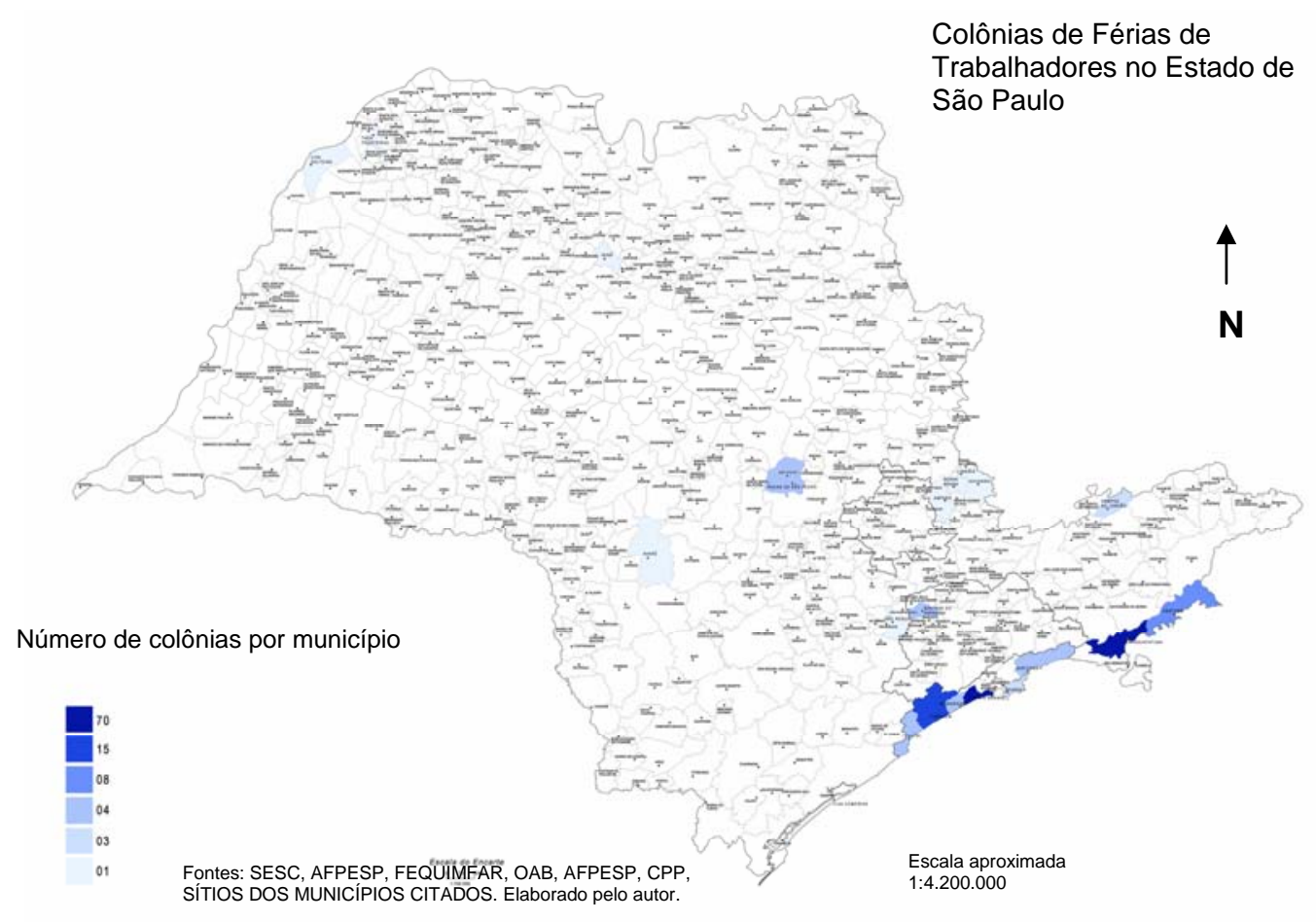


Anexo 5

Baixa Santista

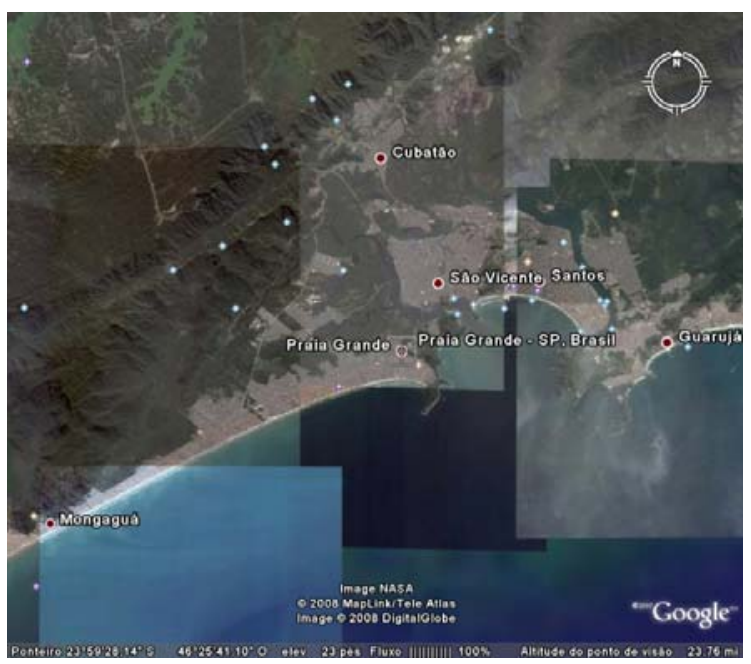

Praia Grande e São Vicente

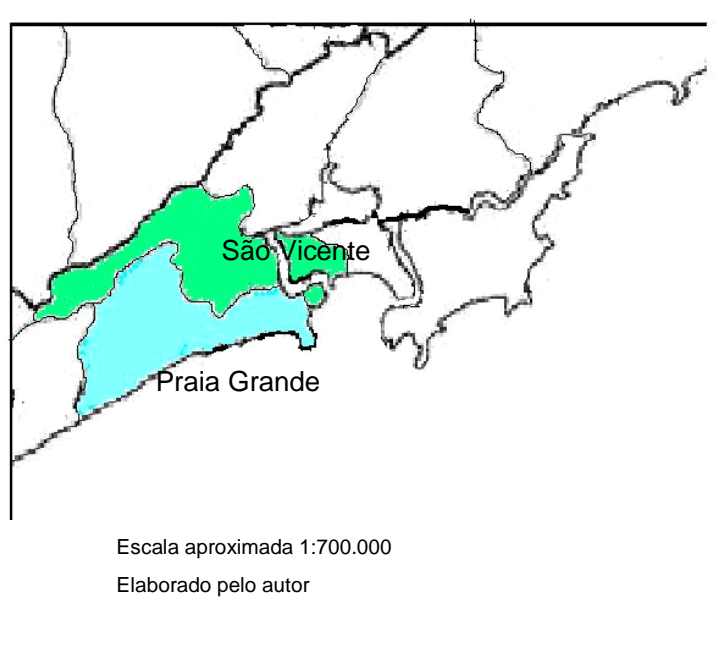


Anexo 6

$\underline{\text { AVENIDA DOS SINDICATOS }}$

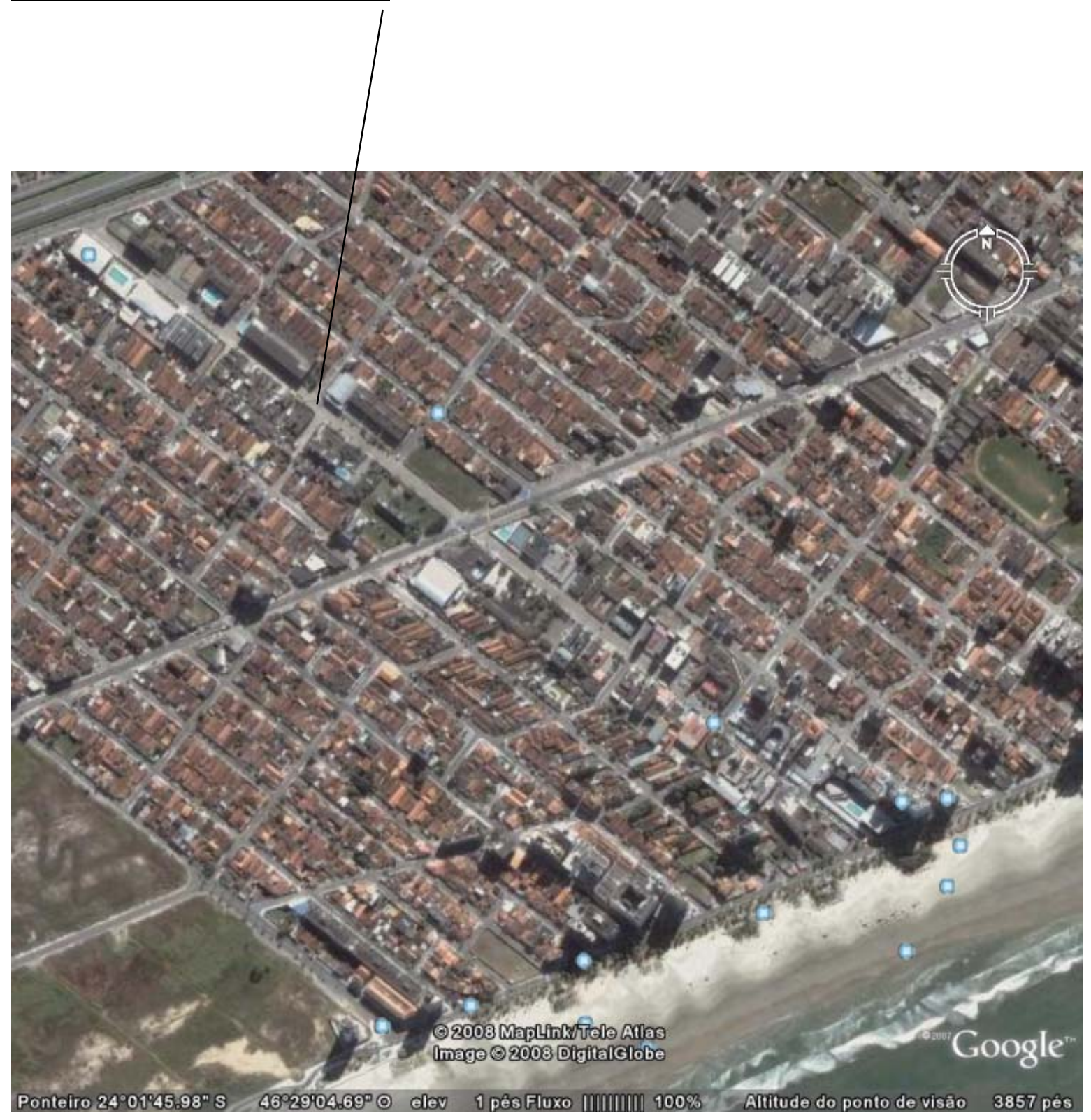


Anexo 7
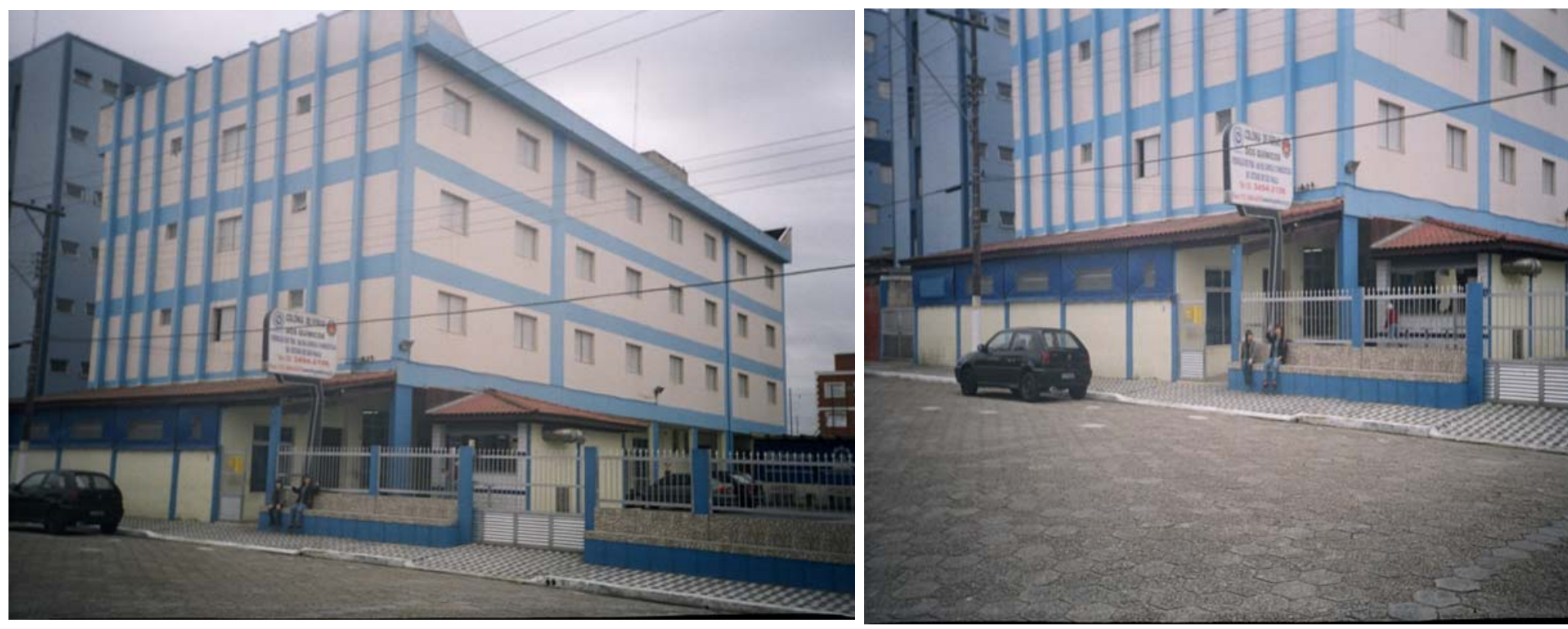

Colônia da Federação dos Químicos e dos Farmacêuticos. Uma das colônias cuja gestão foi terceirizada, o que otimizou a administração desonerando a tarefa dos líderes sindicais e aumentando as taxas de ocupação.

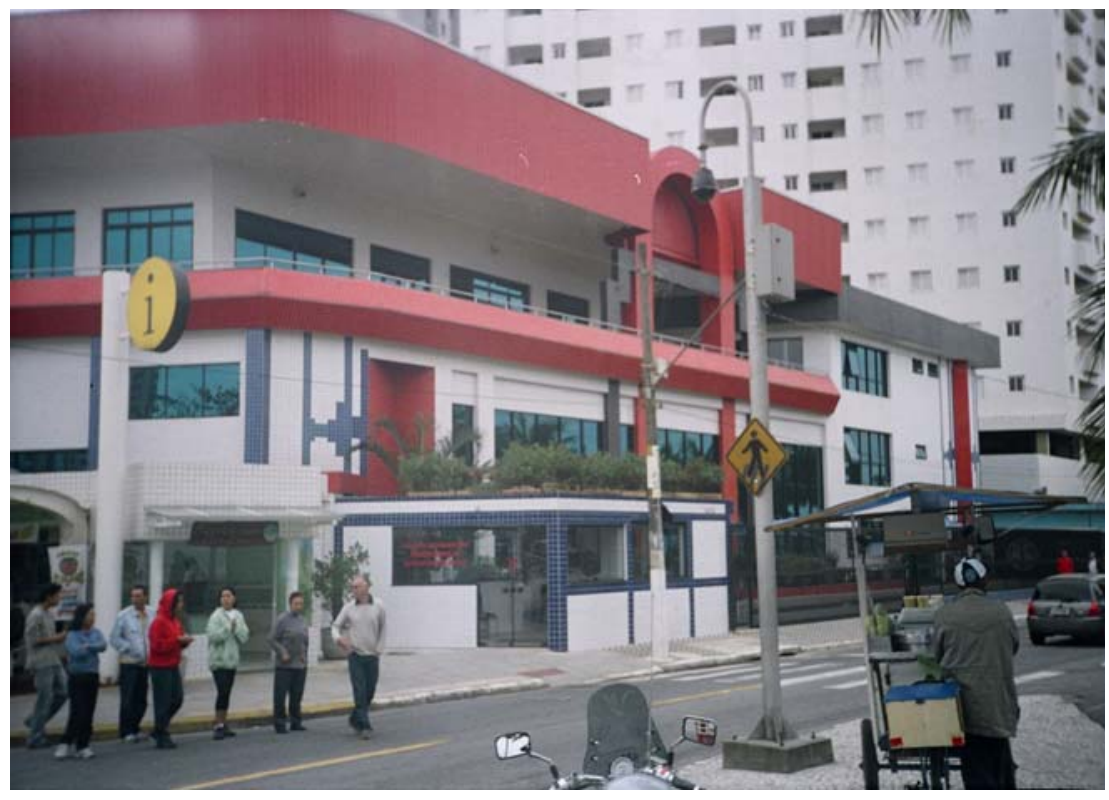

Recepção da Colônia dos Comerciários, com o maior número de leitos de todo o município. Na alta temporada chega a contar com 120 funcionários.

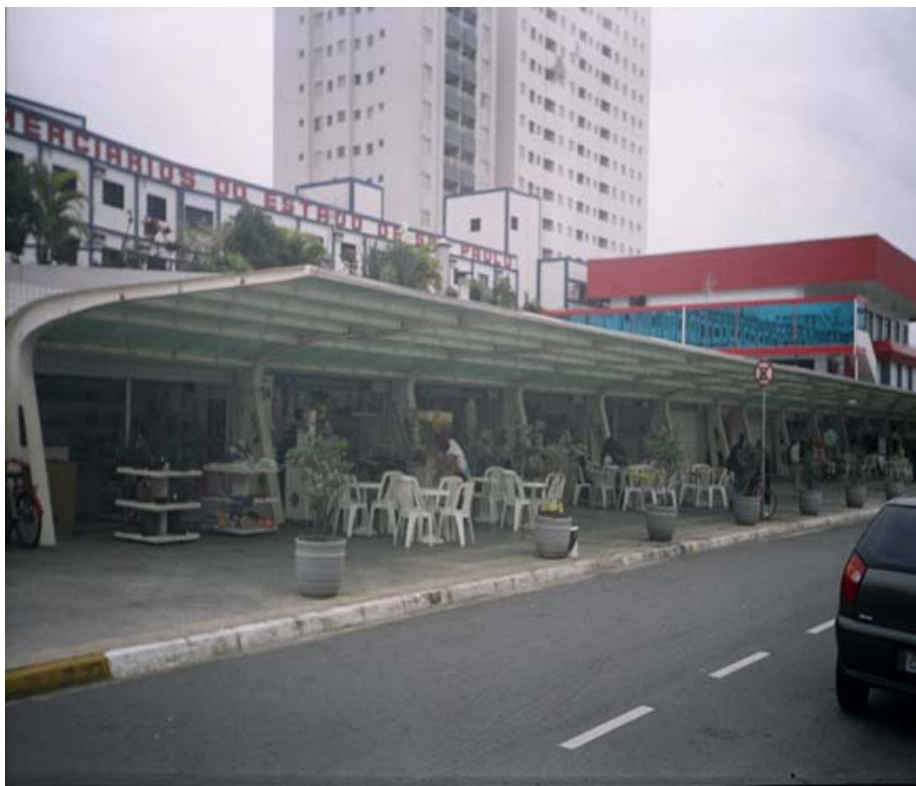

Ao lado da colônia dos Comerciários projeto de revitalização urbana feito pela prefeitura na entrada da Avenida dos Sindicatos 

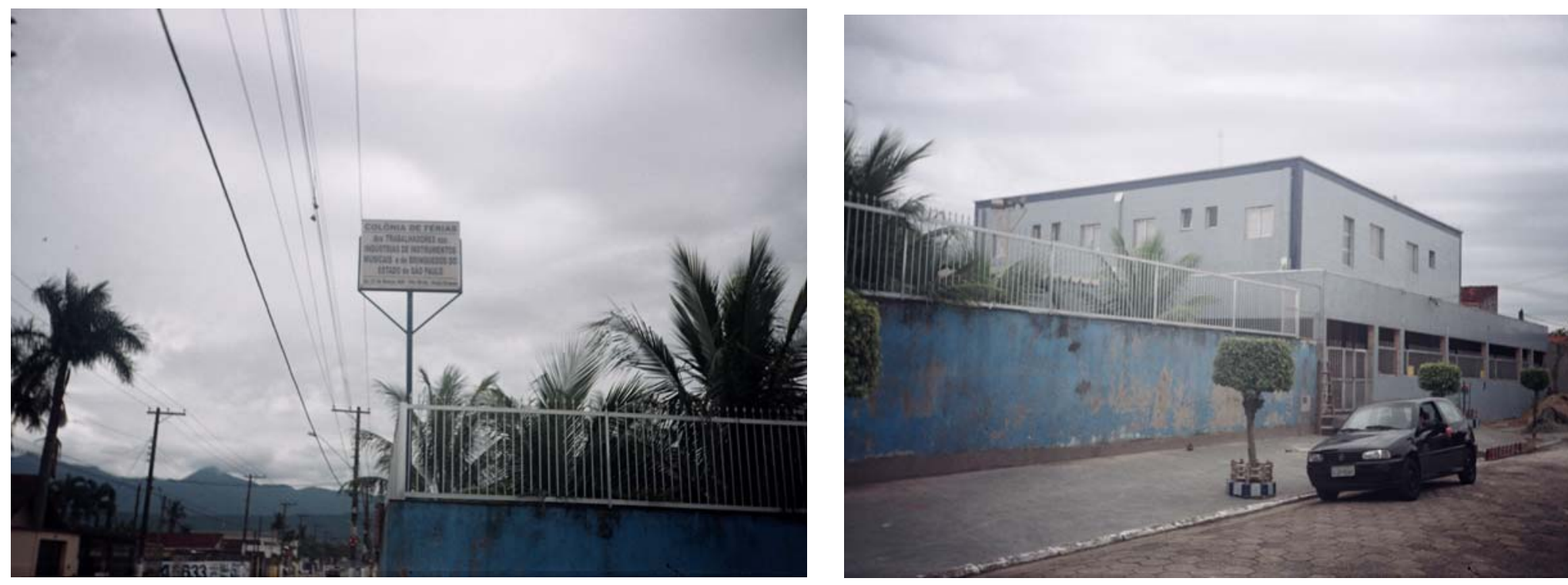

Colônia de férias do Sindicato dos fabricantes de brinquedos e instrumentos musicais, uma das colônias mais antigas de Praia Grande, onde realizamos nosso estudo de caso com levantamento dos custos. A colônia passa por certas dificuldades financeiras, em parte por conta do processo de abertura do mercado nacional que permitiu uma avalanche de produtos estrangeiros no país retirando muitos postos de trabalho.
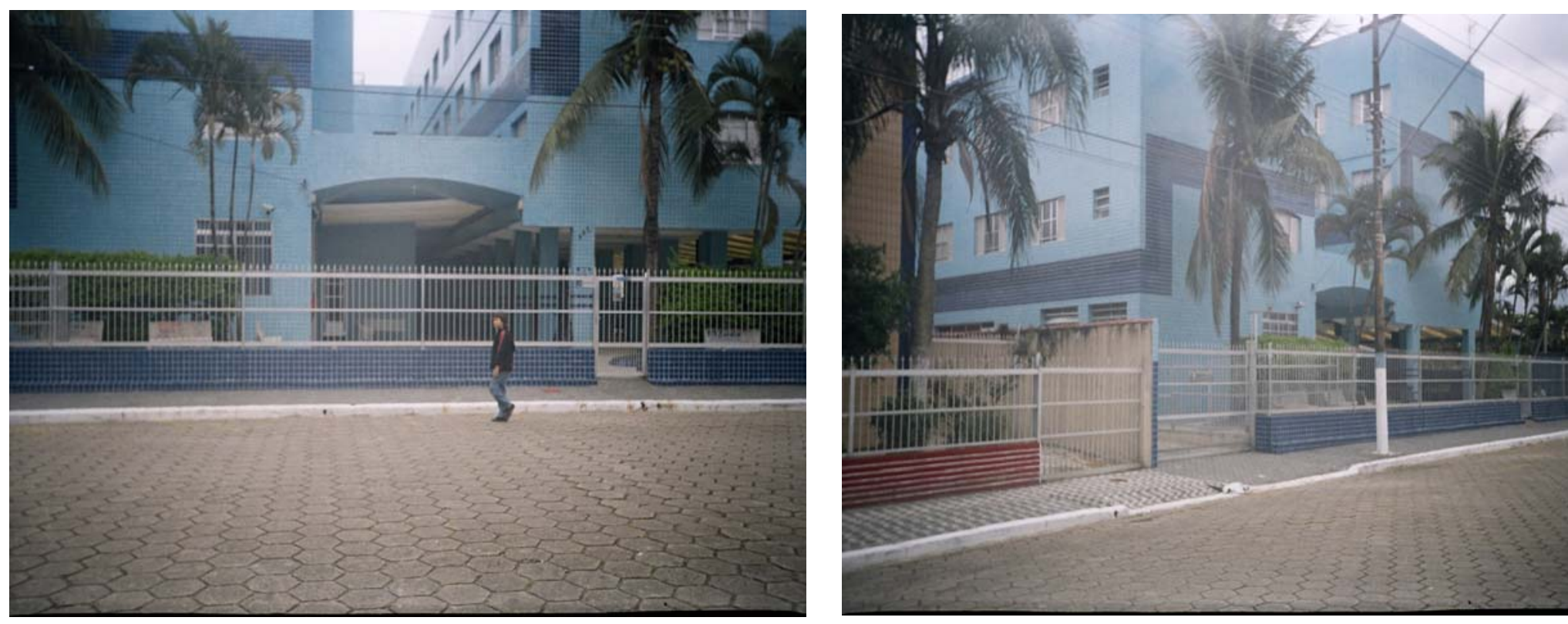

Colônia do Sindicato dos Borracheiros na Avenida dos Sindicatos integrada à Federação dos Químicos 


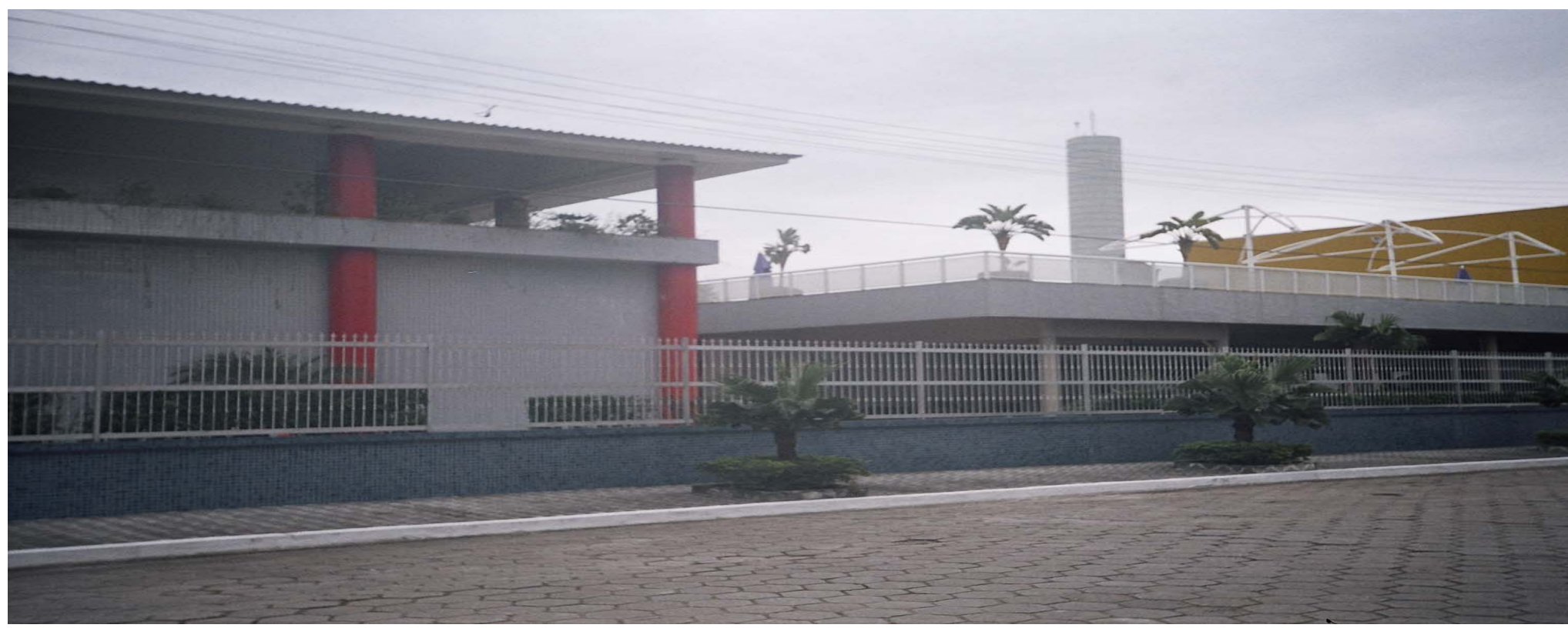

Colônia do Sindicato dos Vendedores, uma das mais modernas, na Avenida dos Sindicatos. Apresenta uma estrutura surpreendente, além de piscina e outros equipamentos tradicionais conta também com um ginásio poli esportivo.

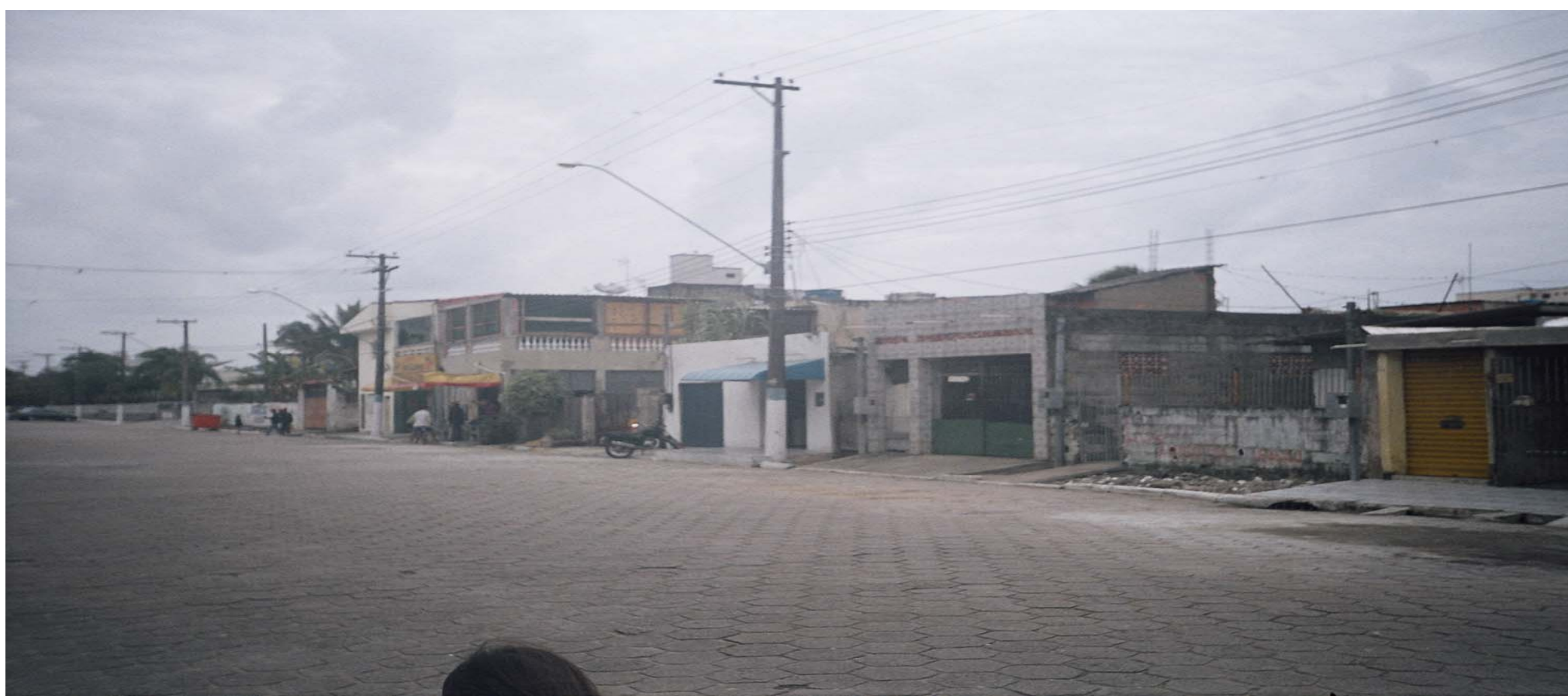

Único trecho da Avenida dos Sindicatos que não é ocupado por colônias, o terreno foi invadido e segundo os moradores há um projeto da prefeitura para serem alocados em área destinada para "moradia popular" (no caso em região próxima aos mangues). 


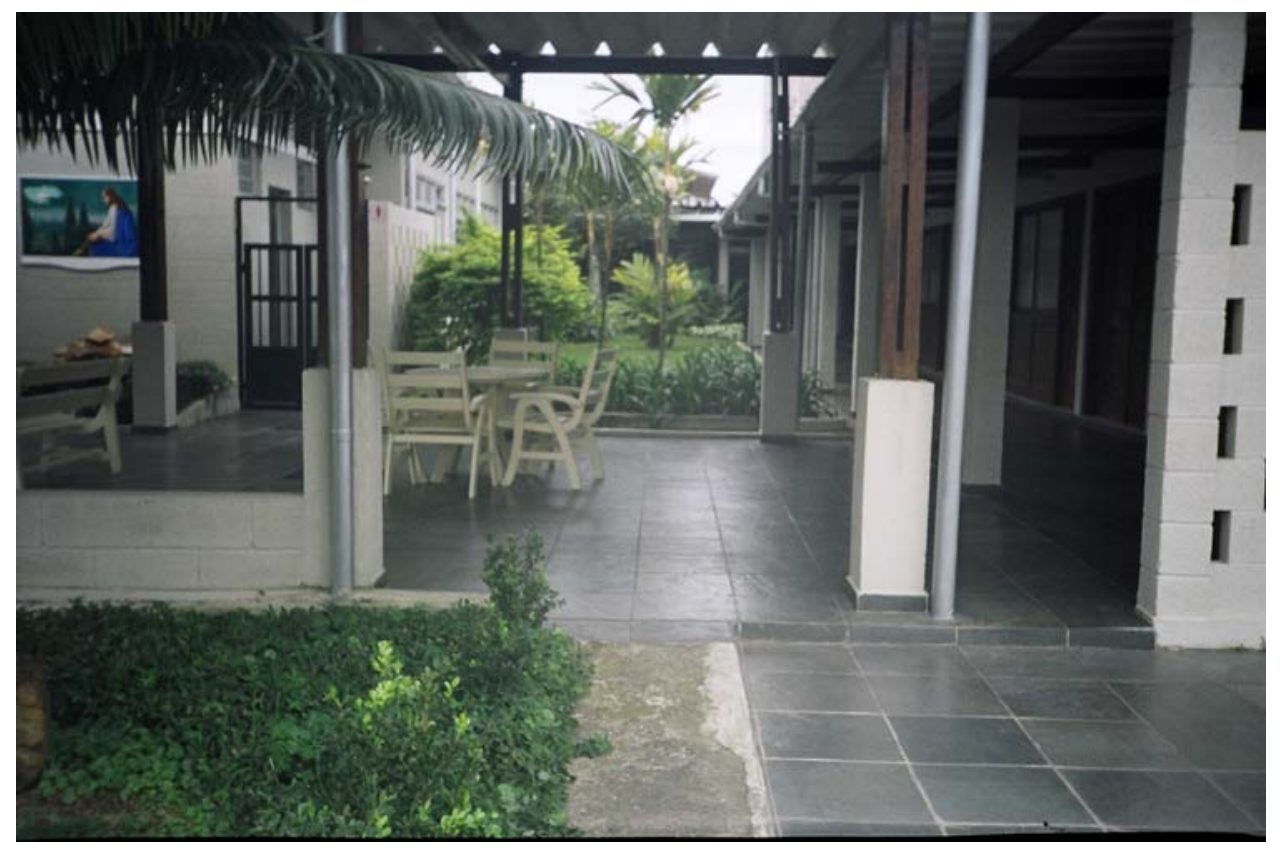

Colônia de Sindicato com agradável espaço interno de convivência.

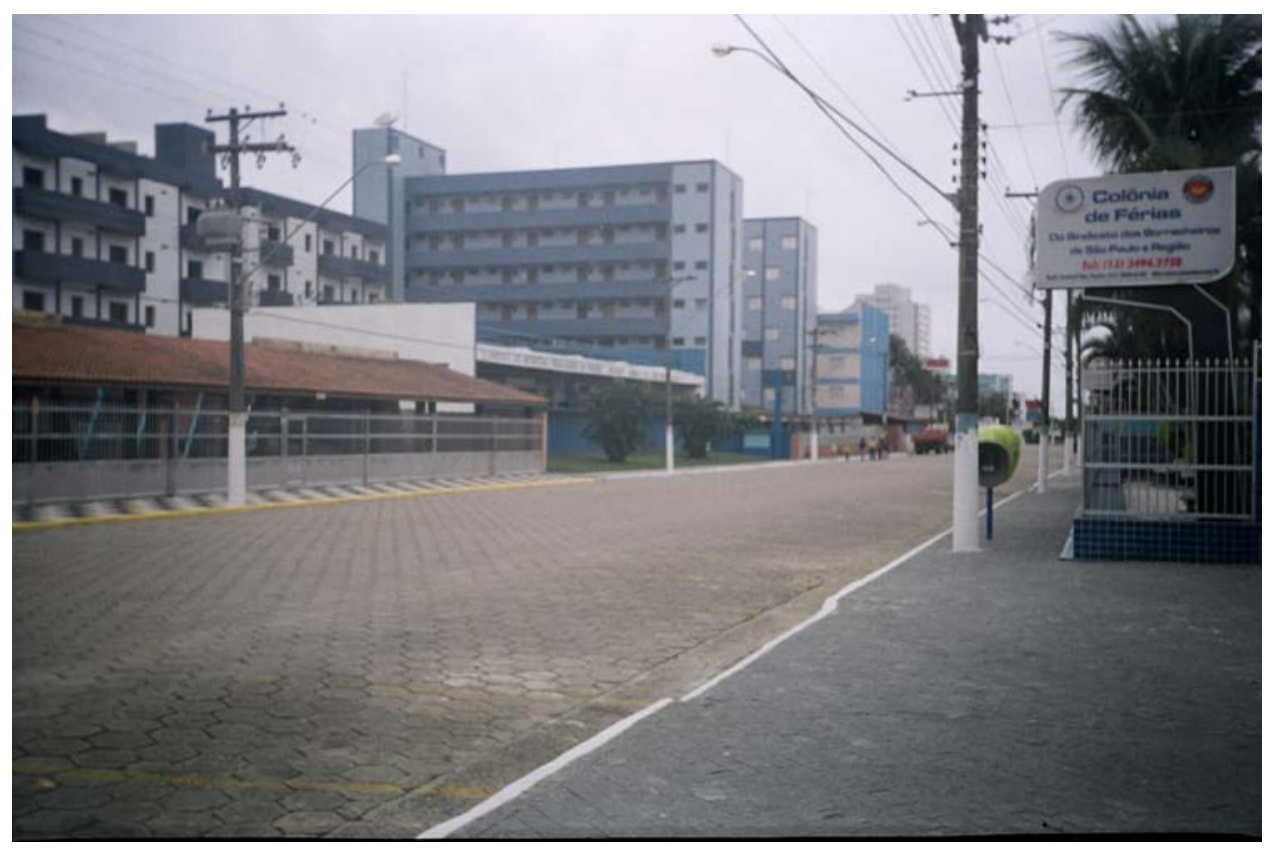

Vista parcial da Avenida dos Sindicatos, a Secretaria de Turismo e do Planejamento Urbano de Praia Grande em consonância com os gestores e lideranças sindicais deveriam se unir com vistas a um projeto com preocupações paisagísticas focando a identidade do lugar. 


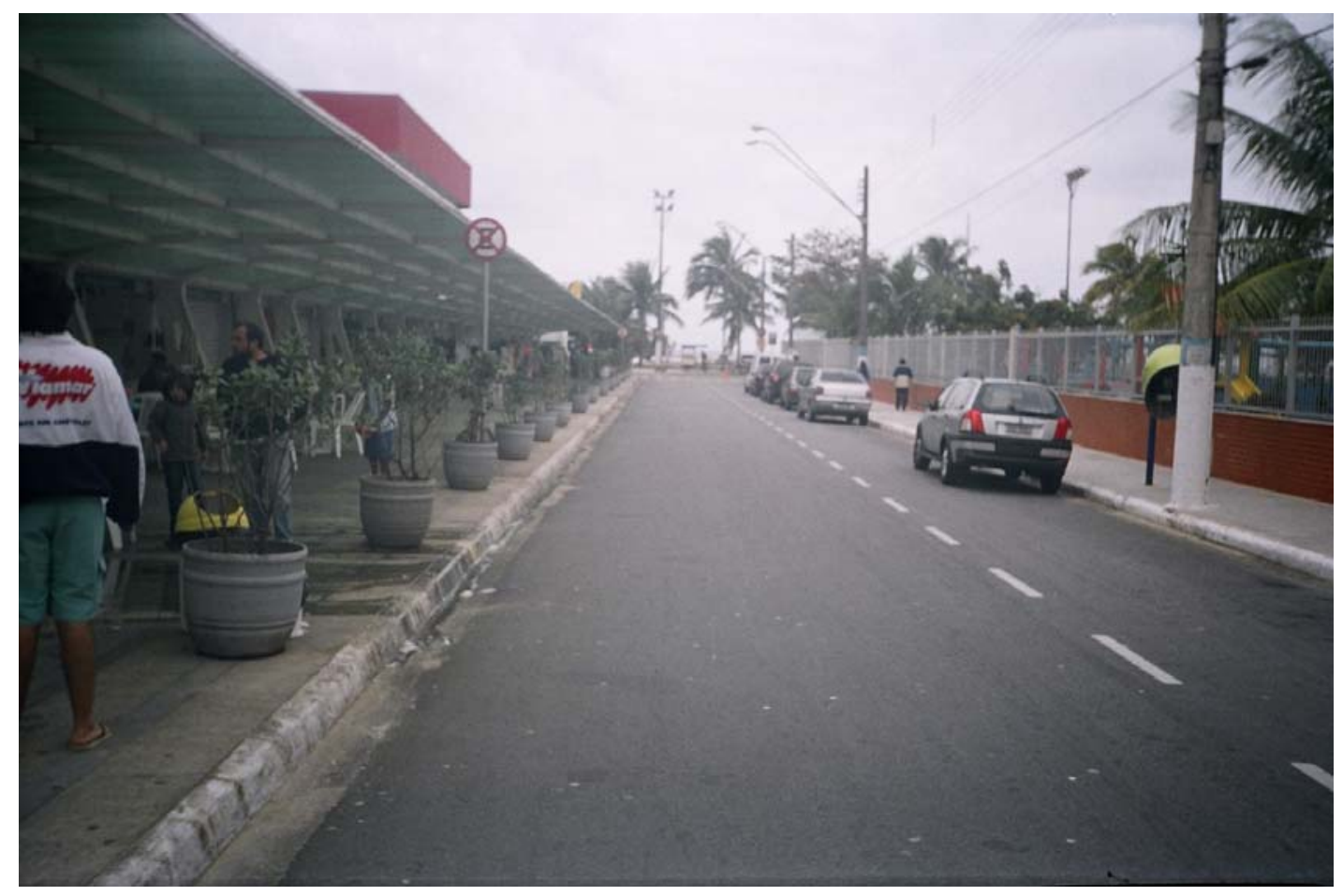

Trecho reurbanizado na Avenida dos Sindicatos que valorizou as colônias ao redor, a idéia poderia ser ampliada por toda a avenida, melhorando a qualidade paisagística. Ao fundo a orla marítima.

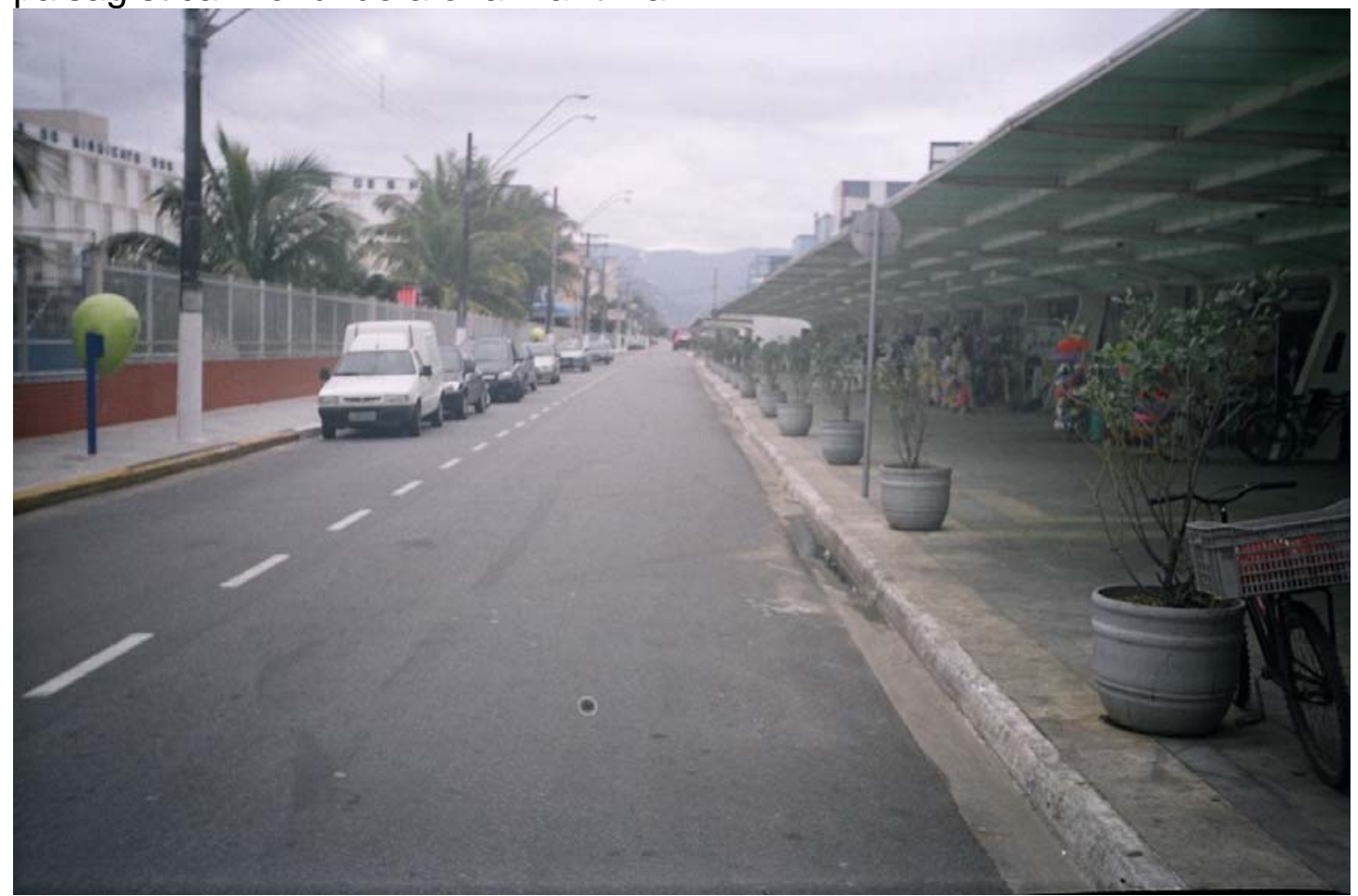

Mesmo trecho em sentido contrário, ao fundo reserva ecológica, que poderia ser alvo de visitações turísticas respeitando obviamente as disposições sobre Zoneamento Ecológico Econômico. 


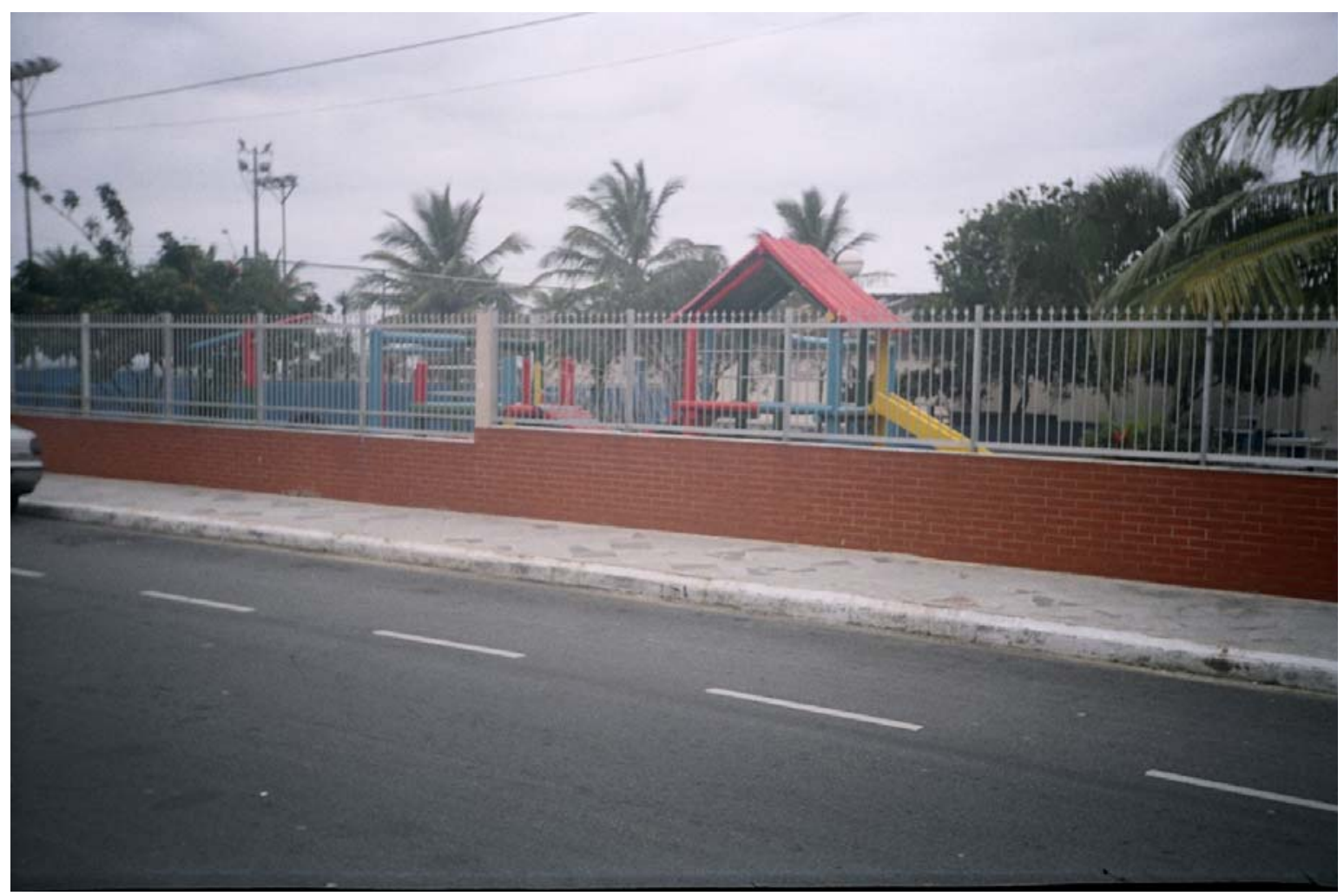

Colônia dos metalúrgicos e seu belo playground valorizando o espaço para o público infantil. 


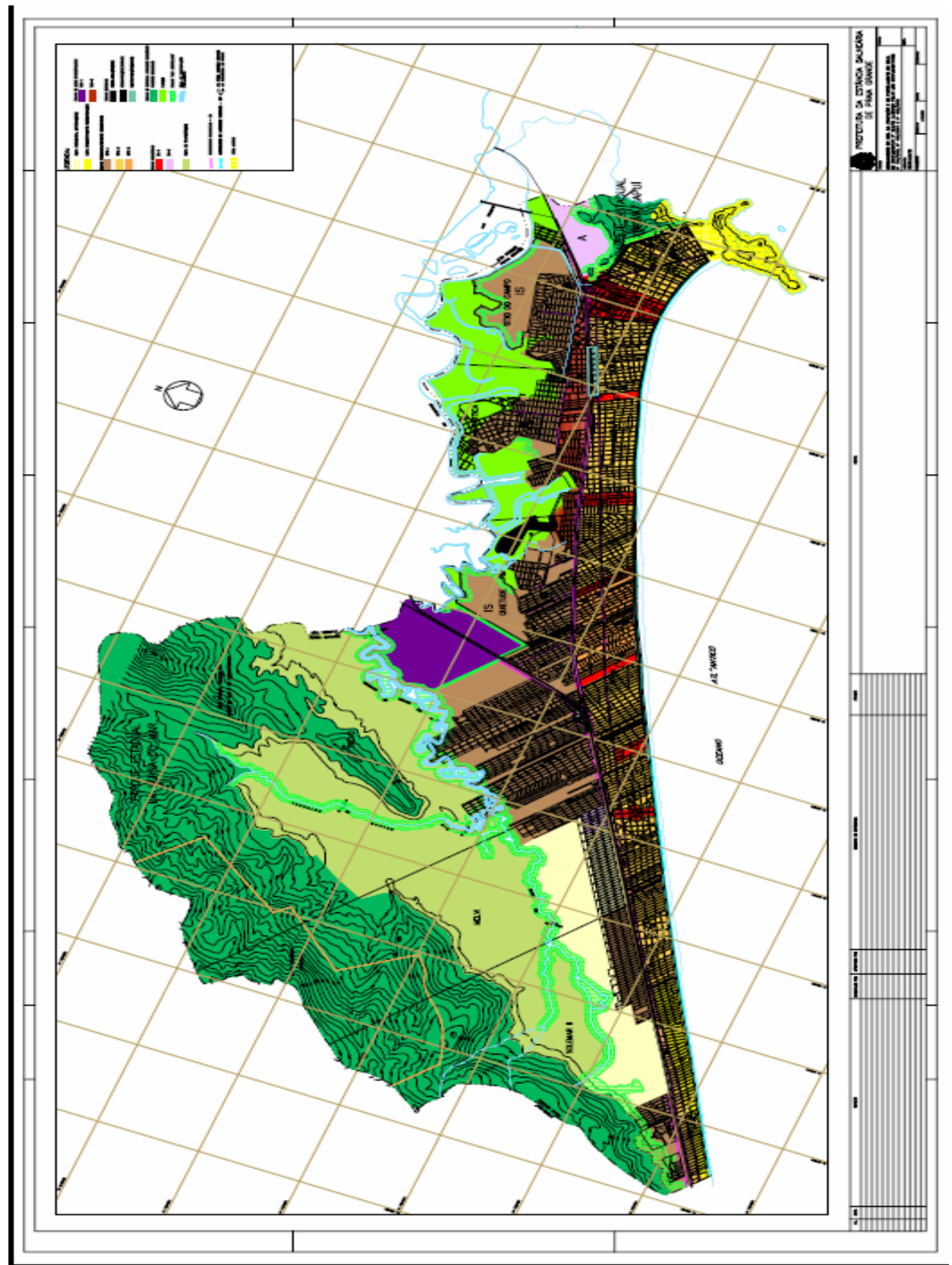

